UNIVERSIDADE DE SÃO PAULO

FACULDADE DE ECONOMIA, ADMINISTRAÇÃO E CONTABILIDADE DEPARTAMENTO DE CONTABILIDADE

PROGRAMA DE PÓS-GRADUAÇÃO EM CONTROLADORIA E CONTABILIDADE

ALBA VALÉRIA MORAES AMARAL ROCHA

INSTITUIÇÕES, AÇÃO SOCIAL E FRAUDES DOS CLIENTES NA INDÚSTRIA DA ÁGUA: UM ESTUDO NA REGIÃO METROPOLITANA DE SÃO PAULO À LUZ DA ECONOMIA INSTITUCIONAL

São Paulo

2018 
Prof. Dr. Vahan Agopyan

Reitor da Universidade de São Paulo

Prof. Dr. Adalberto Américo Fischmann

Diretor da Faculdade de Economia, Administração e Contabilidade

Prof. Dr. Ariovaldo dos Santos

Chefe do Departamento de Contabilidade e Atuária

Prof. Dr. Lucas Ayres Barreira de Campos Barros

Coordenador do Programa de Pós-Graduação em Controladoria e Contabilidade 


\section{INSTITUIÇÕES, AÇÃO SOCIAL E FRAUDES DOS CLIENTES NA INDÚSTRIA DA ÁGUA: UM ESTUDO NA REGIÃO METROPOLITANA DE SÃO PAULO À LUZ DA ECONOMIA INSTITUCIONAL}

\section{Versão corrigida}

Tese apresentada ao Departamento de Contabilidade e Atuária da Faculdade de Economia, Administração e Contabilidade da Universidade de São Paulo como parte dos requisitos para obtenção do grau de Doutor em Ciências, área de concentração: Controladoria e Contabilidade.

Orientador: Prof. Dr. Reinaldo Guerreiro

\section{São Paulo}


Autorizo a reprodução e divulgação total ou parcial deste trabalho, por qualquer meio convencional ou eletrônico, para fins de estudo e pesquisa, desde que citada a fonte.

Rocha, Alba Valéria Moraes Amaral

Instituições, Ação Social e Fraudes dos clientes na indústria da água: Um estudo na região metropolitana de São Paulo à luz da economia institucional / Alba Valéria Moraes Amaral. - São Paulo, 2018.

$154 \mathrm{p}$.

Tese (Doutorado) - Universidade de São Paulo, 2018.

Orientador: Reinaldo Guerreiro

1. Instituições 2. Ação social 3. Fraudes 4. Indústria da água

I. Universidade de São Paulo. Faculdade de Economia, Administração e

Contabilidade. II. Título. 
À Maria Luiza. 



\section{AGRADECIMENTOS}

Primeiramente agradeço a Deus pela vida, saúde e persistência, que me permitiram finalizar este trabalho.

Esse momento simboliza o fechamento de um ciclo que teve início no ano 2000, quando iniciei o curso de graduação em Ciências Contábeis na FEA. Gostaria de agradecer a todos que de alguma forma contribuíram para que eu chegasse até aqui, e àqueles que, mesmo sem contribuir diretamente, torceram verdadeiramente por mim.

Ao professor Dr. Reinaldo Guerreiro, meu ilustre orientador, pessoa pela qual eu nutro grande admiração, enorme respeito, e guardo ótimas lembranças desde as aulas de Gecon na graduação, que me acompanha desde o mestrado, pela disponibilidade, honestidade, paciência e apoio ao longo de todos esses anos.

A todos os professores do PPGCC, em especial ao professor Dr. Fábio Frezatti, Luís Eduardo Afonso, Carlos Alberto Pereira e Luiz Paulo Lopes de Fávero, pelas aulas incríveis, pelo incentivo e contribuições quando membros das bancas de pré-qualificação.

À professora Dra. Basília Maria Baptista Aguirre, do Departamento de Economia, e ao professor Dr. Décio Zylbersztajn, do Departamento de Administração, com quem tive a honra de cursar Economia Institucional e Economia das Organizações, respectivamente, pelos valiosos programas brilhantemente ministrados, e pelos comentários positivos em sala de aula, o que me incentivou a perseverar no tema.

A todos os colegas da turma 2014 do PPGCC que de alguma forma me ajudaram, em especial aos colegas Ricardo Suave, Carolina Venturini, Marco Aurélio dos Santos, Fernanda Kreuzberg, Suilise Berwanger Wille, Denis Alves, Otaviano José Guerra e Rafael Cardoso.

À Sabesp, em especial ao Dr. Rui de Britto Álvares Affonso, Diretor Econômico-Financeiro e de Relações com Investidores, e aos Srs. José Sylvio Xavier, Superintendente de Custos e Tarifas, pelo apoio e autorização para frequentar as aulas presenciais do curso, e ao Sr. Maurício Loureiro, gerente do Departamento de Custos e meu chefe direto, pelo apoio e auxílio para a obtenção dos dados. Pelo fornecimento dos dados relativos às fraudes, agradeço muitíssimo aos Srs. José Maurício F. Maia e Carlos R. Canecchio, do Departamento de Gestão das Relações com Clientes da Metropolitana, e à Sra. Samanta I. Tavares de Souza, atual Superintendente Comercial e de Relacionamento com os Clientes. Pelo fornecimento dos dados referentes aos boletins de ocorrência, agradeço ao Sr. Cesar Augusto Silva Santos e Adílson Rodrigues, gerente de Auditoria e auditor, respectivamente. Ao Sr. Antonio Alves, 
colega do Departamento de Tarifas, agradeço o auxílio para a formatação final do banco de dados.

À minha família: minha mãe, Maria Luiza Moraes Amaral e meu irmão, Clovis Henrique Moraes Amaral, pelo apoio e incentivo nos momentos mais difíceis, pela amizade e disponibilidade em me ouvir; pelas alegrias compartilhadas e pela felicidade e certeza de que sempre estarão ao meu lado, e finalmente, àqueles que já se foram, mas permanecem vivos em minha memória: minha querida avó, Anna Gallo de Moraes, pelas minhas mais doces lembranças da infância, e meu amado pai, Clovis Amaral, por tudo que eu sou. 
"From the day we arrive in the planet, and blinking step into the Sun, there's more to be seen than can ever be seen, more to do than can ever be done.

Some say eat or be eaten, some say live and let live. But all are agreed as they join the stampede, you should never take more than you give...."

(Circle of Life, Elton John \& Tim Rice) 



\section{RESUMO}

$\mathrm{Na}$ indústria da água, as fraudes cometidas pelos clientes para acessar a água sem pagar afetam a receita da empresa, contribuem para aumentar as perdas físicas e interferem na ordem econômica, causando danos à sociedade. Os custos de transação ex post envolvem inspeção in loco se houver suspeita de fraude e execução legal no caso de uma fraude ser confirmada. No entanto, os indivíduos podem reagir de forma diversa frente aos custos e benefícios relacionados ao cumprimento das normas contratuais e legais. Analisamos 115.695 fraudes constatadas pela concessionária entre janeiro de 2010 e junho de 2016 na Região Metropolitana de São Paulo. Os resultados indicaram que a fiscalização não apresentou influência importante sobre a quantidade de fraudes. Na categoria de uso residencial as áreas mais pobres e com baixo nível de instrução formal apresentaram as maiores quantidades de fraudes. Conclui-se que o fraudador típico nesta categoria está na fronteira do crime e assim sendo precisaria de um "incentivo" para escolher não cometer fraude. Nesse caso propomos dois caminhos inter-relacionados: impor um caráter mais educativo do que punitivo às inspeções e instituir um tipo de troca multilateral (Coase, 1960). Por outro lado, nas áreas com nível sócio econômico alto e muito alto apresentaram maior quantidade de fraudes na categoria de uso comercial relativamente às quantidades de fraudes constatadas na categoria de uso residencial. Esse resultado encontra respaldo em Becker (1968; 1974), cujo argumento incorpora o comportamento racional ilegal, e traz à cena o argumento de Hirschmann (1977), de que cabe à sociedade e às firmas tornar as estruturas políticas repressivas efetivas em adesão ao interesse civilizado. Devido às diferenças de governança dentro da empresa e no ambiente legal e social, a validade dos resultados é limitada à RMSP.

Palavras-chave: instituições; ação social; fraudes; indústria da água. 


\begin{abstract}
In water industry, frauds committed by customers to access water without paying affect firm's revenue, contribute to increase physical losses and interfere in the economic order causing harm to society. Ex post transaction costs involve inspection in loco if fraud is suspected and legal enforcement in case a fraud is confirmed. However, individuals may react differently to the costs and benefits of complying with contractual and legal standards. We analyzed the 115,695 frauds registered in management system of the concessionaire between january 2010 and june/2016 in the Metropolitan Region of São Paulo. The results indicated that the inspections did not have an important influence on frauds quantity. Frauds were much more numerous in residential category of use in poorest areas with low level of formal education. It is concluded that typical fraudster in this category is at the border of crime. Therefore, he needs an 'incentive' to choose not commit fraud. In this case we propose two interrelated paths: to impose a more educational than punitive character on the inspections and to institute a type of multilateral exchange (Coase, 1960). On the other hand, in commercial category of use frauds were much more numerous in areas with high and very high socioeconomic level. This result is supported by Becker (1968; 1974), whose argument incorporates the illegal rational behavior and brings to the scene Hirschmann's argument (1977), that it is up to society and firms to make effective repressive political structures in adherence to civilized self-interest. Due to differences in governance within the firm and in legal and social environment, the validity of the results is limited to the MRSP.
\end{abstract}

Keywords: institutions; social action; frauds; water industry. 


\section{LISTA DE TABELAS}

Tabela 1. Elementos Fundamentais: Abordagem Neoclássica X Abordagem Institucional ....37

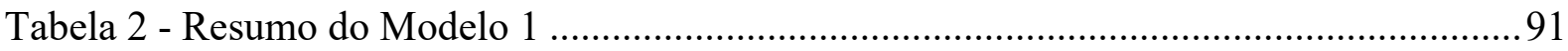

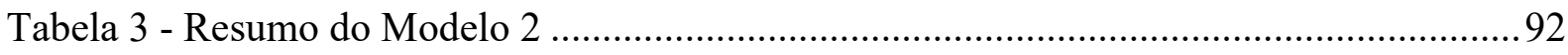

Tabela 4 - resumo do Modelo 3 - Modelo Teórico Final..........................................................95 


\section{LISTA DE ILUSTRAÇÕES}

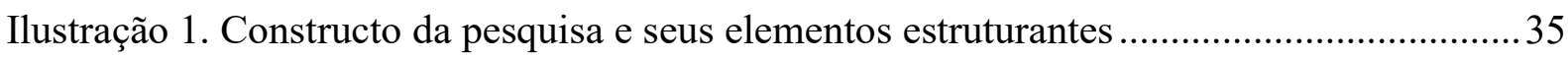

Ilustração 2. Instituições x ética, governança econômica e finanças corporativas ....................48

Ilustração 3. Tradição neoclássica, institucionalista, Teoria das Organizações e ECT .............50

Ilustração 4. Instituições políticas e de governança econômica ..............................................58

Ilustração 5. Forças que atuam sobre as fraudes ..................................................................5

Ilustração 6. Organograma geral da concessionária Sabesp..................................................58

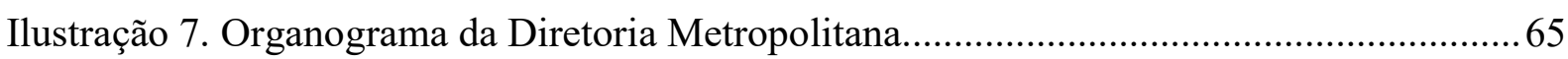

Ilustração 8. Estimativa do impacto das fraudes em termos de volume não faturado...............72

Ilustração 9. Processo de constatação de fraude ..................................................................... 72

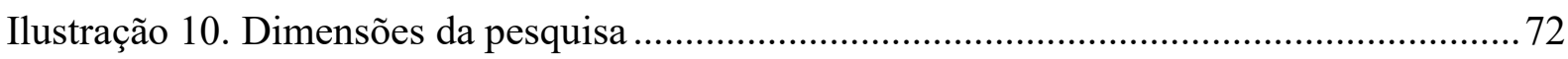

Ilustração 11. Processo de Institucionalização da RMSP ..........................................................73 


\section{LISTA DE GRÁFICOS}

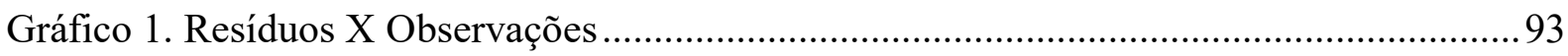

Gráfico 2. Distância de Cook X Observações ......................................................................... 94

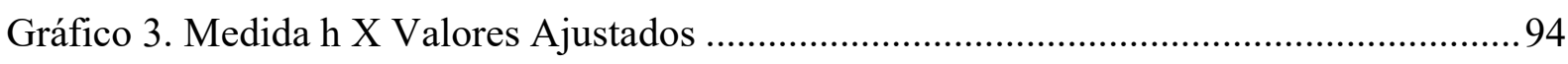

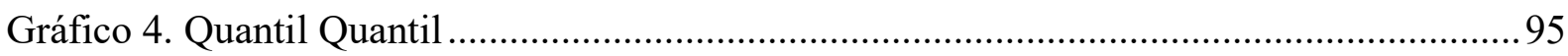




\section{LISTA DE APÊNDICES}

\section{APÊNDICE A}

1. Tabela A.1 Quantidade de Fraudes por RGI ............................................................. 115

2. Tabela A.2. RGIS Reincidentes com mais de 10 Fraudes $X$ Bos.....................................116

3. Tabela A.3 Fraudes por Município - RGIS Reincidentes ................................................ 117

4. Tabela A.4 Fraudes por Unidade de Negócio - RGIS Reincidentes................................ 117

5. Tabela A.5. Fraudes por Atendimento Comercial - RGIS Reincidentes ......................... 117

6 Tabela A.6. Fraudes Totais por Atendimento Comercial ..................................................... 118

7. Tabela A.7. Fraudes Residenciais por 1000 Habitantes - Nível Distrital ........................ 120

8. Tabela A.8. Fraudes Totais por Unidade de Negócio.................................................... 123

9. Tabela A.9. Fraudes Residenciais por 1000 Habitantes - Nível Município ..................... 124

10. Tabela A.10. Fraudes Totais por Categoria de Uso.................................................. 125

11. Tabela A.11. Fraudes Totais por Ramo de Atividade ................................................ 125

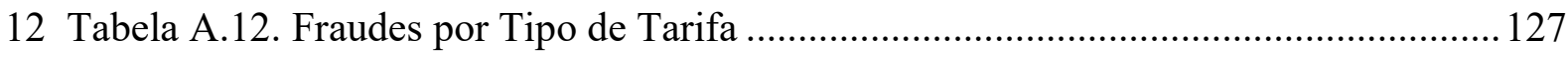

13. Tabela A.13. Fraudes por Tipo de Ligação ................................................................ 127

14. Tabela A.14. Fraudes Comerciais por Unidade de Negócio ........................................... 127

15. Tabela A.15. Atendimentos com maior número de Fraudes Comerciais - Município de SP

16 Tabela A.16. Fraudes na Categoria Comercial por Município e Distrito......................... 128

17. Tabela A.17. Fraudes na Categoria Comercial por 1000 Habitantes -Município e Distrito

18. Tabela A.18. Distritos com maior Proporção de Fraudes Comerciais Comparativamente às Fraudes Residenciais/1000 Hab. ............................................................................ 135

19. Tabela A.19. Fraudes na Categoria Industrial por Unidade de Negócio .......................... 136

20. Tabela A.20. Atendimentos Comerciais com maior número de Fraudes Industriais ....... 136

21. Tabela A.21. Registro de B.O. por Município e Distrito................................................ 136

22. Tabela A.22. Registro de B.O. por Unidade De Negócio ............................................. 139 
23. Tabela A.23. Registro de B.O. por Categoria de Uso

24. Tabela A. 24. Média de Fraudes por Mês por Unidade de Negócio e Categoria de uso.. 139

25 Tabela A. 25. Média de Fraudes por Mês por Categoria de Uso, Município exceto São Paulo e Distrito de SP

24. Gráfico A.1. Taxa de Fraudes por Distrito pela Proporção de Habitantes em Vulnerabilidade Baixíssima

25. Gráfico A.2. Taxa de Fraudes por Distrito pela Proporção de Habitantes em Vulnerabilidade Muito Baixa

26. 27. Gráfico A.4. Taxa de Fraudes por Distrito pela Proporção de Habitantes em Vulnerabilidade Média

28. Gráfico A.5. Taxa de Fraudes por Distrito pela Proporção de Habitantes em Vulnerabilidade Alta (Urbana)

29. Gráfico A.6. Taxa de Fraudes por Distrito pela Proporção de Habitantes em Vulnerabilidade Muito Alta (Aglomerados Urbanos).

30. Gráfico A.7. Taxa de Fraudes por Distrito pela Proporção de Habitantes em Vulnerabilidade Alta (Rural) 


\section{APÊNDICE B}

1. Mapa B1. Mapa de calor em quartis da população por município ................................... 144

2. Mapa B2. Mapa de calor em quartis do número de fraudes por município ...................... 144

3. Mapa B3. Mapa de calor em quartis do número de fraudes residenciais por mil habitantes

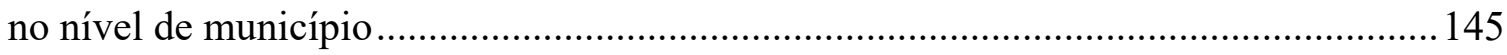

4. Mapa B4. Fraudes em francisco morato e franco da rocha no detalhe............................. 145

5. Mapa B5. Fraudes no município de são paulo no detalhe ................................................ 146

6. Mapa B6. Mapa de calor em quartis da população por distrito ....................................... 147

7. Mapa B7. Mapa de calor em quartis do número de fraudes por distrito .......................... 148

8. Mapa B8. Mapa de calor em quartis do número de fraudes por mil habitantes no nível distrital. 


\section{APÊNDICE C}

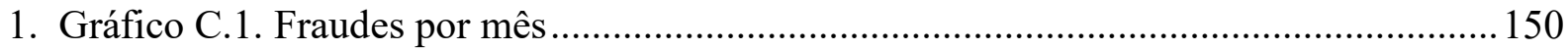

2. Gráfico C.2. Fraudes e vistorias por mês ........................................................................... 150

3. Gráfico C.3. Fraudes por unidades de negócio................................................................ 150

4. Gráfico C.4. Fraudes por unidades de negócio por mês - categoria residencial ............... 151

5. Gráfico C.5. Fraudes por unidade de negócio por mês - categoria comercial ................... 152

6. Gráfico C.6. Fraudes por categoria de uso por mês........................................................... 152

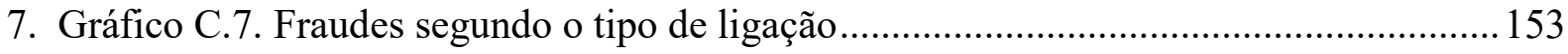

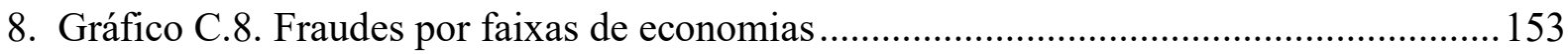

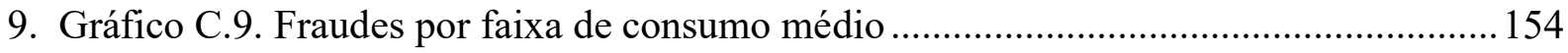




\section{LISTA DE ABREVIATURAS E SIGLAS}

AIC Critério de Informação de Akaike

API Application Programming Interface

BO Boletim de Ocorrência

CDHU Companhia de Desenvolvimento Habitacional e Urbano

CF Constituição Federal

COHAB Companhia Habitacional

CT Custos de Transação

DP Direitos de Propriedade

ECT Economia dos Custos de Transação

IAB Instituto de Arquitetos do Brasil

IBGE Instituto Brasileiro de Geografia e Estatística

IPEA Instituto de Pesquisa Econômica Aplicada

IPVS Índice Paulista de Vulnerabilidade Social

LCE Lei Complementar Estadual

NEI Nova Economia Institucional

PMDI Plano Metropolitano de Desenvolvimento Integrado

RC Rol Comum

RGI Registro Geral Individual

RMSP Região Metropolitana de São Paulo

SABESP Cia de Saneamento Básico do Estado de São Paulo

SEADE Fundação Sistema Estadual de Análise de Dados 


\section{SUMÁRIO}

\section{INTRODUÇÃO}

1.1 Objetivos e questão de pesquisa 25

1.2 Hipóteses e proposições 26

$\begin{array}{lll}1.3 & \text { Justificativa e contribuições esperadas } & 27\end{array}$

2 REFERENCIAL TEÓRICO 31

2.1 A economia do crime 31

2.1.1 Conclusão 34

2.2 A economia institucional 35

2.2.1 Instituições de governança econômica: direitos de propriedade 39

2.2.2 Análise econômica dos direitos de propriedade (Barzel,1989) 41

2.2.3 Direitos de propriedade, custos de transação e externalidades 43

2.2.4 Direitos de propriedade e enforcement legal 44

$\begin{array}{ll}2.2 .5 \mathrm{O} \text { contrato e a firma } & 47\end{array}$

2.2.6 Conclusão 49

2.3 A ação social 51

2.3.1 A teoria da ação social (Coleman, 1986; 1990

2.3.2 Ação econômica e estrutura social (Granovetter, 1985; 1992; 2005) 55

$\begin{array}{ll}2.3 .3 \text { Conclusão } & 57\end{array}$

3 FRAUDES EM SERVIÇOS DE ÁGUA NA RMSP: ASPECTOS GERAIS 59

3.1. Caracterização da empresa

$\begin{array}{ll}3.2 \text { Fraudes comerciais em serviços públicos } & 61\end{array}$

3.2.1 Governança das fraudes comerciais na RMSP 65

$\begin{array}{ll}3.2 .2 \text { Conclusão } & 70\end{array}$

4 METODOLOGIA $\quad 71$

4.1 Estratégia de pesquisa $\quad 71$

$\begin{array}{ll}\text { 4.1.1 Campo da pesquisa } & 72\end{array}$

4.1.2 Amostra 74

$\begin{array}{ll}\text { 4.1.3 Coleta de Dados } & 75\end{array}$ 


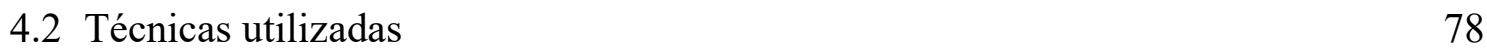

$\begin{array}{ll}\text { 4.2.1 Análise por referência geográfica } & 78\end{array}$

4.2.2 Análise por séries temporais e análise descritiva 78

4.2.3 Análise inferencial (Manski, 1995) 80

$\begin{array}{ll}\text { 4.2.3.1 Seleção das Variáveis } & 81\end{array}$

5 RESULTADOS $\quad 85$

5.1 Análise descritiva 85

$\begin{array}{llr}5.1 .1 & \text { Reincidências } & 85\end{array}$

5.1.2 Atendimentos comerciais, unidades de negócio e distritos 86

5.1.3 Categoria de uso residencial 86

$\begin{array}{ll}\text { 5.1.4 Tipo de tarifa e tipo de ligação } & 87\end{array}$

$\begin{array}{ll}\text { 5.1.5 Categoria de uso comercial e industrial } & 87\end{array}$

5.1.6 Aplicação da lei: registro de BO 88

5.2 Análise por referência geográfica 88

5.3 Análise das séries temporais 89

5.4 Análise inferencial $\quad 90$

6 DISCUSSÃO DOS RESULTADOS 97

$\begin{array}{ll}6.1 \text { Reincidência } & 97\end{array}$

$\begin{array}{lr}\text { 6.2 Perfil dos fraudadores } & 98\end{array}$

6.3 Aspectos sócio econômicos $\quad 99$

6.4 Mecanismos de monitoramento 100

6.5 Ação social 101

7 CONSIDERAÇÕES FINAIS 103

REFERÊNCIAS 107

$\begin{array}{ll}\text { APÊNDICE A } & 115\end{array}$

$\begin{array}{ll}\text { APENNDICE B } & 144\end{array}$

APÊNDICE C 150 


\section{INTRODUÇÃO}

A abordagem econômica do crime (Becker, 1974) incorpora o comportamento racional ilegal com base nas premissas neoclássicas e traz uma proposição sobre como o custo da fraude pode ser medido. Tal proposição envolve instituições internas e externas à firma. Assim, é lícito afirmar que a abordagem institucional estende e complementa a abordagem neoclássica. Além disso, na abordagem institucional a gestão assume papel relevante para melhorar o desempenho da firma, o que não ocorre na abordagem neoclássica.

As proposições de Commons (1931) representam uma das fontes mais importantes para o estabelecimento da vertente institucionalista na teoria econômica, a qual inclui as instituições como uma variável relevante para explicar os resultados econômicos. Para North (1990), elas impõem restrições à interação humana por meio de normas formais e informais.

A sociologia também reconhece a importância das normas. A teoria da ação social (Coleman, 1986; 1990) trabalha com duas correntes principais: uma alinhada à teoria institucionalista, onde a norma é definida como uma propriedade de um sistema social governando o comportamento dos indivíduos; e outra alinhada à teoria neoclássica, onde a maximização da utilidade é o princípio de toda ação individual, e nesse contexto o conceito de norma é desnecessário.

Para North (1990), a falta de brilho no crescimento econômico nos países em desenvolvimento é resultado dos altos custos de transação. Manzetti \& Rufin (2006) afirmam que as altas taxas de pobreza encontradas nesses países e os elementos culturais locais também são aspectos importantes a ser considerados.

Segundo Coase (1991), a existência de custos de transação leva ao surgimento da empresa. A explicação para isso é que uma empresa só poderia continuar existindo se realizasse sua função de coordenação a um custo menor do que seria incorrido por meio de transações de mercado e a um custo menor do que essa mesma função poderia ser desempenhada por outra empresa. Sistemas econômicos eficientes, portanto, dependem não só dos mercados como também das áreas de planejamento das organizações. Assim sendo, é necessário introduzir os custos de transação na análise econômica de modo explícito.

Por outro lado, num mundo com regime de custos de transação positivos o sistema legal tem importância crucial, pois o verdadeiro objeto das negociações não são as entidades físicas, mas os direitos de realizar certas ações sobre essas entidades (direitos de propriedade), direitos esses estabelecidos pelo sistema legal (Coase, 1991). Segundo Demsetz (1964), o 
valor negociado entre as partes depende crucialmente dos direitos de propriedade e de como são executados (enforcement legal). Nesse contexto, é lícito concluir que a execução dos direitos de propriedade pela aplicação da lei tem influência sobre os custos de monitoramento ex post da firma, e, portanto, sobre sua eficiência econômica.

Custos de transação são os custos incorridos para: (i) obter informação; (ii) mensurar as dimensões valoráveis das mercadorias, serviços e agentes e (iii) executar os acordos. $\mathrm{Na}$ abordagem da nova economia institucional os custos de transação têm a função de conectar as instituições aos custos de produção. Williamson (1985) enfatiza os custos de transação incorridos pelas organizações para monitorar os contratos (custos de transação ex post). Demsetz (1964) enfatiza os custos de transação representados pelas instituições voltadas para proteger os direitos de propriedade.

$\mathrm{Na}$ indústria da água as fraudes cometidas pelos usuários contra a concessionária para acessar o bem sem pagar contribuem para aumentar o nível de perdas físicas e trazem malefícios para a competitividade e a ordem econômica. As fraudes envolvem ligações clandestinas, manipulações do hidrômetro, violação de lacres entre outras práticas ilícitas, e constituem crime implicando em sanção para o infrator, desde que seja aplicada a lei por meio das instituições da polícia e da justiça. Portanto, esse problema implica em altos custos de transação para a firma e para a sociedade. Nesse sentido, verificar a influência que a aplicação da lei exerce sobre os usuários que fraudam têm relevância para reduzir esses custos e melhorar a gestão.

Esse trabalho busca investigar a influência que os mecanismos de governança internos, externos, bem como a estrutura social, exercem sobre a decisão de fraudar. Aqui esses mecanismos são representados respectivamente pela fiscalização da concessionária, pela aplicação da lei, pelo perfil sócio econômico do cliente e o modo como ele se enquadra no sistema das normas legais e sociais. Portanto, o trabalho encontra-se no limiar entre a norma estabelecida e a realidade fática. Nesse sentido, a pesquisa busca associar a realidade factual a elementos e premissas teóricas da economia institucional.

A seguir apresentamos o constructo da pesquisa e seus elementos estruturantes. 


\section{Ilustração 1. Constructo da pesquisa e seus elementos estruturantes}

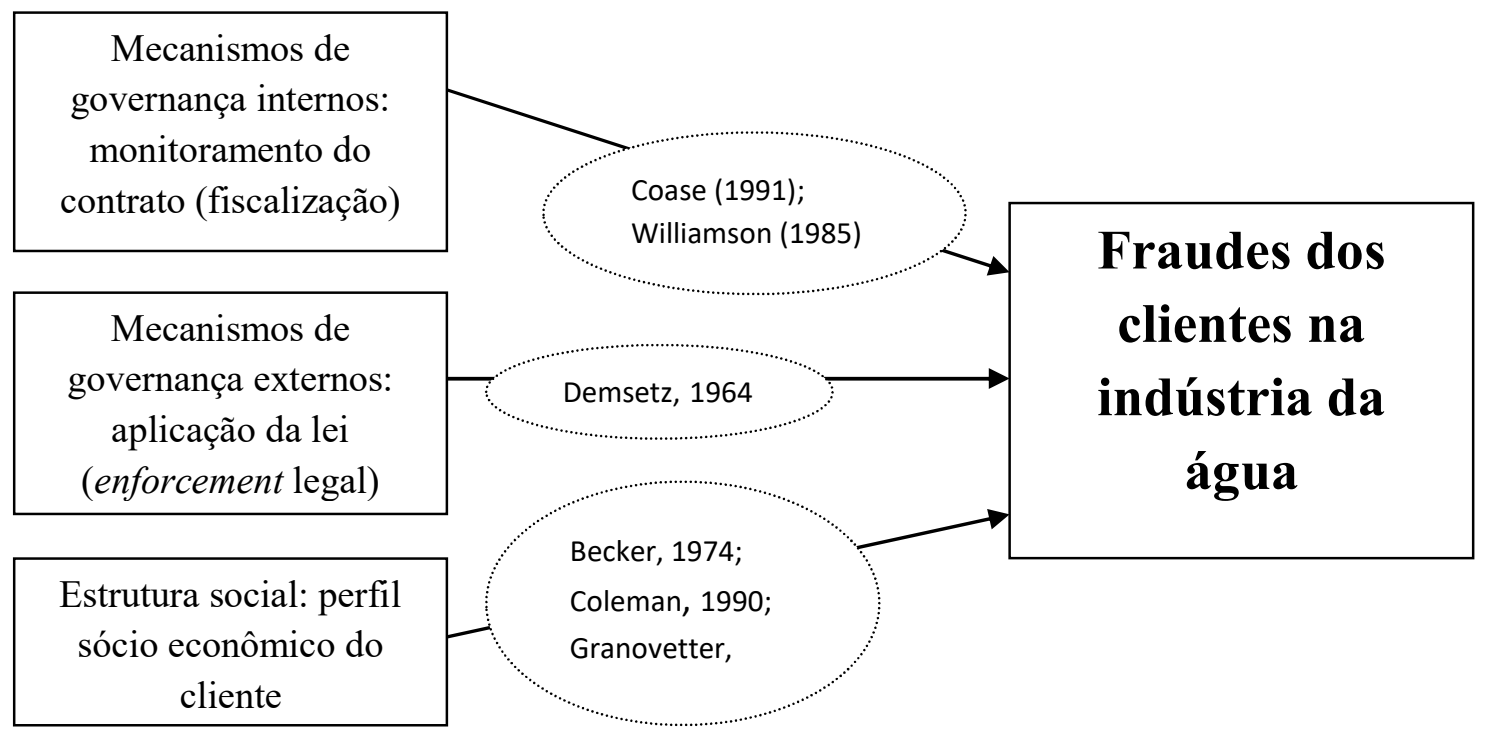

Fonte: a autora

\subsection{Objetivos e questão de pesquisa}

Entre os fraudadores, uma parte vive em áreas irregulares e não tem acesso à água tratada e distribuída pela concessionária. Segundo Guimarães (2015), no Brasil o ordenamento jurídico de acesso aos serviços de infraestrutura de abastecimento de água e esgotamento sanitário está subordinado ao direito de propriedade e ao direito ambiental. Assim, o assentamento de redes de água e esgoto em áreas irregulares ou com restrições ambientais é passível de acionamento judicial pelo Ministério Público.

A falta de acesso à água pode ser vista como uma má alocação dos direitos de propriedade. Entretanto, esse grupo de fraudadores não será objeto do presente estudo, que foca especificamente o grupo de usuários que mantém relação contratual com a concessionária. Nesse grupo, ressalta-se que a estrutura tarifária tem papel importante, pois em razão da essencialidade do bem a tarifa tem impacto econômico, social e político e assim sendo, pode contribuir para uma alocação ineficiente dos direitos de propriedade.

Nesse contexto, partindo do pressuposto que as instituições interferem nos resultados econômicos, que as normas sociais governam as ações dos indivíduos e que o não 
cumprimento das normas legais está sujeito a sanções, o objetivo geral desse estudo é investigar como as instituições internas, de monitoramento do contrato, externas, voltadas para proteger os direitos de propriedade, e a estrutura social influenciam o comportamento de fraude na indústria da água na Região Metropolitana de São Paulo.

Relacionada ao objetivo geral, esse estudo buscará responder à seguinte questão de pesquisa: Na indústria da água, como as instituições internas, voltadas para monitorar o contrato entre firma e cliente; externas, voltadas para aplicar a lei, e a estrutura social influenciam o comportamento de fraude do cliente na Região Metropolitana de São Paulo?

Para atingir o objetivo geral essa pesquisa se guiará pelos seguintes objetivos específicos:

1. Investigar a incidência de fraudes;

2. Investigar o perfil dos fraudadores;

3. Investigar qual o efeito que as instituições de monitoramento interno do contrato, representadas pela fiscalização, exercem sobre a decisão de fraudar;

4. Investigar qual o efeito que as instituições externas voltadas para a proteção dos direitos de propriedade, representadas pelo enforcement legal, exercem sobre a decisão de fraudar;

5. Investigar qual o efeito do perfil sócio econômico do cliente sobre a incidência de fraudes;

6. Modelar a incidência de fraudes comerciais no município de São Paulo;

7. Investigar como o fraudador se enquadra no sistema de normas formais e informais.

\subsection{Hipóteses e proposições}

Apresentamos as seguintes hipóteses a serem testadas:

a) Quanto ao monitoramento ex post do contrato, representado pela fiscalização da concessionária:

H0: A fiscalização da concessionária não tem efeito significativo sobre a quantidade de fraudes constatadas.

H1: A fiscalização da concessionária tem efeito significativo sobre a quantidade de fraudes constatadas.

b) Quanto aos mecanismos externos de proteção dos direitos de propriedade: 
H0: A aplicação do enforcement legal pela concessionária não tem efeito significativo sobre a quantidade de fraudes constatadas.

H1: A aplicação do enforcement legal pela concessionária tem efeito significativo sobre a quantidade de fraudes constatadas.

c) Quanto ao efeito do nível sócio econômico do cliente:

H0: O nível sócio econômico do cliente não tem influência sobre a quantidade de fraudes constatadas.

H1: O nível sócio econômico do cliente tem influência sobre a quantidade de fraudes constatadas.

Adicionalmente, esse estudo apresenta ainda as seguintes proposições:

P1: Na indústria da água na RMSP o típico fraudador apresenta um comportamento moldado pelo ambiente social e voltado para obedecer às normas formais e informais.

P2: Na indústria da água na RMSP o típico fraudador apresenta um comportamento atomizado e guiado pelo auto interesse com malícia.

\subsection{Justificativa e contribuições esperadas}

O que acontece entre a compra dos fatores de produção e a venda dos bens produzidos? A resposta a essa questão ainda é ignorada. As firmas utilizam a maioria dos recursos dos sistemas econômicos modernos, e a forma como esses recursos são utilizados depende das decisões administrativas das mesmas, e não diretamente do mercado. Desse modo, a eficiência do sistema econômico depende em grande parte de como as firmas conduzem seus negócios. Uma questão relevante nesse contexto é qual a contribuição da gestão, uma vez que o sistema de preços já provê a coordenação necessária (Coase, 1991).

Segundo Santos (2011), o campo das práticas ilegais dos consumidores no âmbito dos serviços públicos é de grande relevância para a comunidade acadêmica, mas ainda pouco explorado. Deixar de considerar a perspectiva ética do consumidor pode levar a um conhecimento incompleto do tema, uma vez que o consumidor é o protagonista da relação de troca. 
Segundo Leal (2009), o tema dos serviços públicos no Brasil se aloja no âmbito da ordem econômica, haja vista sua inexorável intervenção - direta ou indiretamente - no campo de atividades produtivas do mercado de trabalho. Trabalhando na Sabesp há 20 anos em 2018, empresa de economia mista que fornece serviços de abastecimento de água e esgotamento sanitário no Estado de São Paulo, temos vislumbrado a oportunidade de relacionar aspectos teóricos ao mundo real. No mestrado abordamos os contratos de serviços operacionais contínuos firmados entre a concessionária e as empreiteiras, focando o problema lock-in na relação bilateral e o monitoramento ex post, o que equivale à cláusula de fiscalização do contrato, desenhada para minimizar os riscos de expropriação pela contraparte, tendo como premissas o oportunismo e a racionalidade limitada, no âmbito da economia dos custos de transação (Williamson, 1985). Desse modo, conseguimos vincular o problema de pesquisa à dimensão organizacional e à visão da natureza humana preconizada pela nova economia institucional.

No presente trabalho o objeto novamente é o contrato, mas dessa vez entre concessionária e cliente, com foco específico sobre as fraudes cometidas pelo último, que lesam o faturamento da concessionária e geram malefícios à sociedade. A fundamentação teórica, além da economia dos custos de transação, abrange ainda outros dois importantes conceitos teóricos do programa da nova economia institucional: as instituições enquanto normas formais e informais e a teoria da ação social. Desse modo, entendemos que às duas dimensões teóricas acima citadas, adicionamos também a dimensão de processos sociais ao problema.

Para Coase (1991), o principal obstáculo enfrentado pelos pesquisadores na organização industrial é a falta de dados disponíveis sobre os contratos e as atividades das empresas. Assim, entendemos que esse trabalho contribui à medida que traz à luz informações gerenciais de uma importante organização que atua no setor de água brasileiro. Adicionalmente, espera-se contribuir no sentido de fornecer uma análise dos efeitos que os mecanismos de monitoramento do contrato exercem sobre o comportamento fraudulento do cliente.

No âmbito da literatura institucional espera-se contribuir no sentido de fornecer uma análise dos efeitos que as instituições voltadas para proteger os direitos de propriedade exercem sobre o comportamento fraudulento do cliente.

$\mathrm{Na}$ abordagem economia-sociologia espera-se contribuir no sentido de analisar o comportamento fraudulento segundo as vertentes da super e subsocialização do indivíduo. 
No âmbito do controle gerencial, espera-se contribuir no sentido de estabelecer um link entre o controle interno e externo, partindo da premissa de que a efetividade do segundo contribui para reduzir os custos do primeiro.

Na sequência, no capítulo dois apresentamos os conceitos teóricos que dão sustentação ao estudo; no capítulo três discorremos sobre as fraudes na indústria da água na RMSP e o monitoramento feito pela concessionária; no capítulo quatro apresentamos a abordagem metodológica do trabalho; no capítulo cinco apresentamos os resultados, que são discutidos no capítulo seis, e no capítulo sete apresentamos nossas considerações finais. 


\section{REFERENCIAL TEÓRICO}

Iniciamos esse capítulo apresentando a abordagem econômica do crime (Becker, 1974; Ehrlich, 1973), que incorpora o comportamento racional ilegal com base nas premissas neoclássicas e traz uma proposição sobre como o custo da fraude pode ser medido. Uma vez que tal proposição envolve instituições internas e externas à firma, na sequência apresentamos os conceitos teóricos da economia institucional, ressaltando os custos de transação e as instituições. Finalmente, fechamos o referencial teórico com a teoria da ação social, que envolve o conceito de normas e o comportamento individual.

\subsection{A economia do crime}

Já no século XIX buscava-se atestar a existência de correlações entre a criminalidade e determinadas variáveis econômicas. Entretanto, a vertente econômica denominada análise econômica do crime surgiu apenas em 1968, com o trabalho seminal de Gary Becker, cujo pressuposto é de que a opção por praticar um ato ilícito é resultado de uma análise que confronta o benefício vislumbrado a partir de tal ato com o potencial custo associado.

Becker (1974) coloca a seguinte questão: 'o que determina a quantidade e o tipo de recursos e punições usados para impor uma norma?' A partir do levantamento dos custos, representados pelos gastos públicos e privados com os diversos tipos de crime, o autor faz uma análise do custo do crime. A ideia subjacente é que uma teoria útil do comportamento criminoso pode prescindir de teorias especiais de inadequações psicológicas ou herança de traços especiais. O pressuposto é que os indivíduos maximizam o bem-estar tal como eles o concebem, quer sejam egoístas, altruístas, leais, rancorosos ou masoquistas. Além disso, seu comportamento é prospectivo e assumido como consistente ao longo do tempo.

$\mathrm{O}$ custo da fraude pode ser medido em termos de recursos da empresa dedicados à sua detecção, mais o custo do uso das instituições públicas relacionadas à punição do infrator, mais a perda de receita da empresa. A análise econômica do crime incorpora $o$ comportamento racional ilegal e outras ações anti sociais (Becker, 1974).

Dois fatores exercem influência importante sobre a decisão de cometer ou não um ato ilícito: (i) a quantidade percebida de fisscalização, que está diretamente relacionada à probabilidade de ser pego; e (ii) caso venha a ser pego, a probabilidade percebida de ser punido associada ao tipo e severidade da punição. Pelo lado do cálculo do benefício 
decorrente do ato ilícito, o potencial infrator leva em consideração os custos de planejar e executar o ato, incluindo o tempo despendido, que poderia ser empregado em atividades socialmente aceitas, e o custo moral (Jorge, 2012).

As ações são limitadas pela renda, tempo, memória imperfeita, capacidade de cálculo e outros recursos limitados, bem como pelas oportunidades disponíveis na economia. Estas oportunidades são determinadas pelas ações privadas e coletivas de outras pessoas e organizações. Apesar do pressuposto de que o comportamento é racional, 'racionalidade' não significa materialismo, pois reconhece que muitas pessoas são constrangidas por considerações éticas, e não cometem crimes mesmo que estes sejam rentáveis e não haja perigo de detecção. Contudo, a polícia e as cadeias seriam desnecessárias se tais atitudes sempre prevalecessem.

A quantidade de crime é determinada não somente pela racionalidade e preferências dos criminosos, mas também pelo ambiente econômico e social criado pelas políticas públicas, incluindo gastos com policiamento e punições para diferentes crimes e oportunidades de emprego, escola e programas de treinamento. Claramente, o tipo e quantidade de empregos legais disponíveis bem como a lei, a ordem e o enforcement são parte integrante da abordagem econômica do crime.

Ehrlich (1973) incorpora o incentivo tanto para praticar ações lícitas quanto ilícitas. Sua tese é de que ao violar a lei o indivíduo corre o risco de reduzir sua riqueza e bem-estar, pois fica sujeito a pagar uma penalidade em termos pecuniários ou perda da liberdade, que terá que ser descontada dos benefícios auferidos. Uma alternativa seria se engajar em atividades lícitas, que também podem estar sujeitas a riscos específicos. O ganho líquido em ambas as atividades é sujeito à incerteza. Assim, um modelo simples de escolha entre atividades legais e ilegais pode ser formulado dentro da estrutura da teoria econômica da escolha em condições de incerteza. A hipótese central é de que num determinado período, se ambas as atividades forem mutuamente exclusivas, o indivíduo faria a escolha comparando a utilidade esperada associada a cada uma isoladamente. Nesse modelo os infratores são livres para combinar atividades legítimas e ilegítimas ou ocasionalmente mudar de uma para outra em determinados períodos.

Akerlof e Yellen (2000, apud Rodrigues, 2005) ressaltaram a importância da comunidade para o funcionamento do sistema judiciário, uma vez que a condenação dos criminosos depende da colaboração de testemunhas, numa abordagem indireta de relação entre a pobreza e o crime através da noção de "feudos" ou territórios à margem do poder do 
estado. Nestes modelos a oferta de crime está em grande medida relacionada ao controle de territórios por quadrilhas que substituem o poder de polícia e justiça do estado. Assim, em se tratando de comunidades à margem dos serviços de proteção e justiça do estado, a dimensão dos direitos prevalece sobre a questão da renda e da visão custo e benefício enfatizada nos modelos de Becker e Ehrlich. Nesse caso o fator sociológico é preponderante, ou seja, a influência da "comunidade" é decisiva sobre as escolhas individuais.

Akerlof e Kranton (2000) ressaltam a influência da comunidade sobre as escolhas individuais sob o aspecto dos ganhos e perdas de identidade envolvidos na escolha entre adaptar-se ou não à cultura dominante.

No Brasil, estudos antropológicos realizados em favelas do Rio de Janeiro evidenciaram que em decorrência da falta de cidadania (ou "pobreza de direitos"), a atuação das instituições de justiça e segurança do estado mostra-se ineficaz nas comunidades pobres. Nessas áreas grupos criminosos encontram brechas para "substituir" determinadas funções do estado. Esses estudos salientam os elementos de ordem moral que atuam sobre a "escolha" de muitos jovens dessas comunidades por uma vida à margem da lei (Rodrigues, 2005).

Segundo Wang \& Wheeler (2005), dado a dominância dos métodos de enforcement e controle nos EUA e Canadá, a literatura tem focado nos determinantes do compliance com padrões legais. Nesse contexto, o trabalho anterior de Becker (1968) sobre a economia do crime e as punições proveu um ponto de partida natural: o agente que aplica a lei (o regulador) tenta identificar e penalizar o infrator (non-compliant). No modelo básico o infrator ganha uma penalidade fixa, cujo valor esperado depende da probabilidade de identificação. Para induzir a um compliance maior o legislador tem duas opções: aumentar a penalidade ou reforçar o monitoramento e o enforcement.

Para Becker \& Stigler (1974), os tipos de crime que não são associados diretamente a vítimas tendem a não receber a devida atenção da sociedade. Outro ponto é que a estrutura de incentivos à honestidade envolvida na remuneração dos enforcers, que costuma ser muito menor do que os ganhos dos violadores, pode levar a um declínio da qualidade do enforcement. Finalmente, os custos de transação para verificar se a outra parte é confiável podem ser gerenciáveis para violadores e enforcers. Assim, ações ilícitas repetitivas e altamente lucrativas podem explicar o desenvolvimento do crime organizado, pois fazer arranjos com juízes ou com a polícia é menos factível para indivíduos do que para um grupo organizado. 


\subsubsection{Conclusão}

A partir do pressuposto neoclássico da maximização do bem-estar, Becker (1974) concebe a análise econômica do crime e propõe que o custo da fraude pode ser medido em termos não só da perda de receita da firma, como em termos de recursos dedicados à sua detecção mais o custo do uso das instituições públicas relacionadas à punição do infrator. Desse modo, os principais fatores que influenciam a decisão de cometer ou não um ato ilícito são: (i) a quantidade percebida de fiscalização empreendida pela firma para detectar as fraudes; (ii) caso a fiscalização venha a detectar a fraude, a probabilidade de que a firma venha a acionar as instituições públicas visando punir criminalmente o infrator e (iii) caso o infrator venha a ser punido criminalmente, o custo moral decorrente da pena. Tanto a quantidade de fiscalização quanto o acionamento das instituições de enforcement envolvem custos de transação elevados para a firma.

Akerlof e Yellen (2000, apud Rodrigues, 2005) ressaltam a importância da comunidade tanto para o funcionamento do sistema judiciário quanto pelo poder marginal que exercem sobre os indivíduos que vivem em territórios desprovidos de direitos legalmente constituídos. Assim, a condição social e econômica do indivíduo tem relevância no contexto do fenômeno estudado. Desse modo, a físcalização da firma, a aplicação da lei e a influência da comunidade sobre o comportamento dos indivíduos desprovidos de direitos são variáveis que teoricamente apresentam grande potencial para explicar a quantidade de ocorrência das fraudes.

Finalmente, outras reflexões que concernem às potenciais explicações acima mencionadas seriam sobre o que seria mais eficaz para reduzir a quantidade de fraudes: aumentar a penalidade ou o monitoramento; capturar uma quantidade menor de fraudes e puni-las severamente ou capturar uma quantidade maior e puni-las moderadamente. Aumentar a penalidade é difícil e custoso, pois envolve uma mudança na lei. Além disso, é necessário verificar se a regra atual está sendo cumprida, pois caso não esteja, os recursos investidos para mudá-la não trarão retorno algum. Assim, resta o caminho de aumentar o monitoramento, que implica também em aumento de custos.

Entretanto, se mais fraudadores forem capturados, empresa e Estado deverão ter capacidade para puni-los, caso contrário os recursos investidos no aumento do monitoramento também não trarão retorno. Assim, o aumento do monitoramento implica em aumentar também a capacidade administrativa e punitiva. Conclui-se que o importante é punir o 
indivíduo, ou seja, responsabiliza-lo pelo ato ilícito cometido. O caminho então seria aumentar a eficiência dos mecanismos de monitoramento disponíveis, buscando 'multiplicar' o efeito das punições aplicadas.

\subsection{A economia institucional}

Instituições podem ser definidas como ação coletiva no controle, liberação e expansão da ação individual. Essa definição busca sintetizar um princípio universal a partir do qual emergem não só os conceitos éticos de direitos e deveres e conceitos econômicos de segurança, conformidade, liberdade e exposição, como também os conceitos de ativos e passivos, diretamente ligados às finanças corporativas, área da qual deriva grande parte dos dados e metodologia da economia institucional (Commons, 1931). A ilustração a seguir busca representar essa síntese.

Ilustração 2. Instituições x ética, governança econômica e finanças corporativas

\section{Ética}

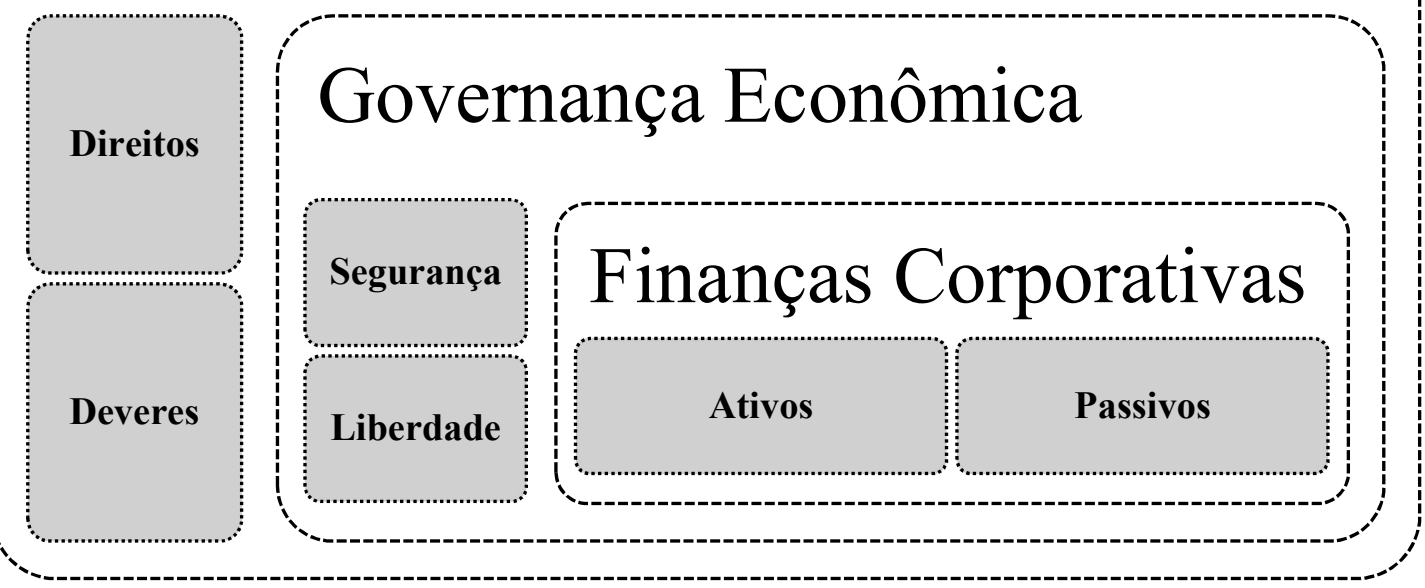

Fonte: a autora.

Nelson \& Sampat (2001) definem instituições como tecnologias sociais que moldam e dão suporte ao comportamento racional. Elas importam porque criam as condições básicas para a interação humana, e à medida que aumentam a previsibilidade dos comportamentos, 
impactam positivamente o grau de segurança da decisão tomada. Além disso, podem excluir ações muito custosas e incentivar ações potencialmente produtivas para todos.

Segundo Hodgson (2006), instituições são simultaneamente estruturas objetivas, exógenas ao indivíduo, como também rebentos subjetivos que emergem de "dentro da cabeça humana".

Para North (1990), as instituições são criadas para reduzir o conflito inerente às interações humanas e reduzir a incerteza. Elas são compostas por regras formais (direito romano, common law, regulações), regras informais (convenções, normas e regras auto impostas de comportamento) e características executivas de ambas.

Segundo Eggertsson (1990), instituições são regras sociais e políticas e exercem influência importante sobre os resultados econômicos. Além disso, elas afetam tanto o desempenho quanto o desenvolvimento econômico e determinam o custo de várias ações factíveis bem como a distribuição da riqueza (Eggertsson, 1990; Greif, 1993).

As instituições políticas mais importantes são as leis. Leis restringem as ações dos indivíduos e definem custos e benefícios reciprocamente estendidos às ações de terceiros (Buchanan 1971, North 1990, Greif 1993).

Para Greif (1993), a sociedade se organiza por meio de instituições econômicas, legais, políticas e de enforcement moral. Essa organização, juntamente com a transmissão de informação e os mecanismos de coordenação, afeta profundamente tanto seu desempenho quanto seu crescimento econômico, e também determina o custo de várias ações factíveis, bem como a distribuição da riqueza.

Searle (2005) propõe que para entender o que é uma instituição é preciso analisar a natureza dos fatos institucionais e como eles diferem de outros fatos. Na sua visão o papel das instituições não é restringir comportamentos, mas criar novos tipos de relações de poder:

The essential role of human institutions and the purpose of having institutions is not to constrain people as such, but, rather, to create new sorts of power relationships. Human institutions are, above all, enabling, because they create power, but it is a special kind of power. It is the power that is marked by such terms as: rights, duties, obligations, authorizations, permissions, empowerments, requirements, and certifications. I call all of these deontic powers (Searle, J. R., 2005).

A abordagem da Nova Economia Institucional acrescenta as instituições como uma restrição crítica para explicar o desenvolvimento econômico e analisa o papel dos custos de transação enquanto conexão entre as instituições e os custos de produção. Adicionalmente 
essa abordagem modela o processo político como um fator determinante na performance das economias. Assim, o constructo migra de um enfoque econômico puro para um enfoque cujo resultado econômico depende de variáveis institucionais, oriundas da área do Direito, e de variáveis organizacionais. A Tabela 1 compara os elementos das abordagens neoclássica e institucional.

Tabela 1. Elementos fundamentais: abordagem neoclássica $X$ abordagem institucional

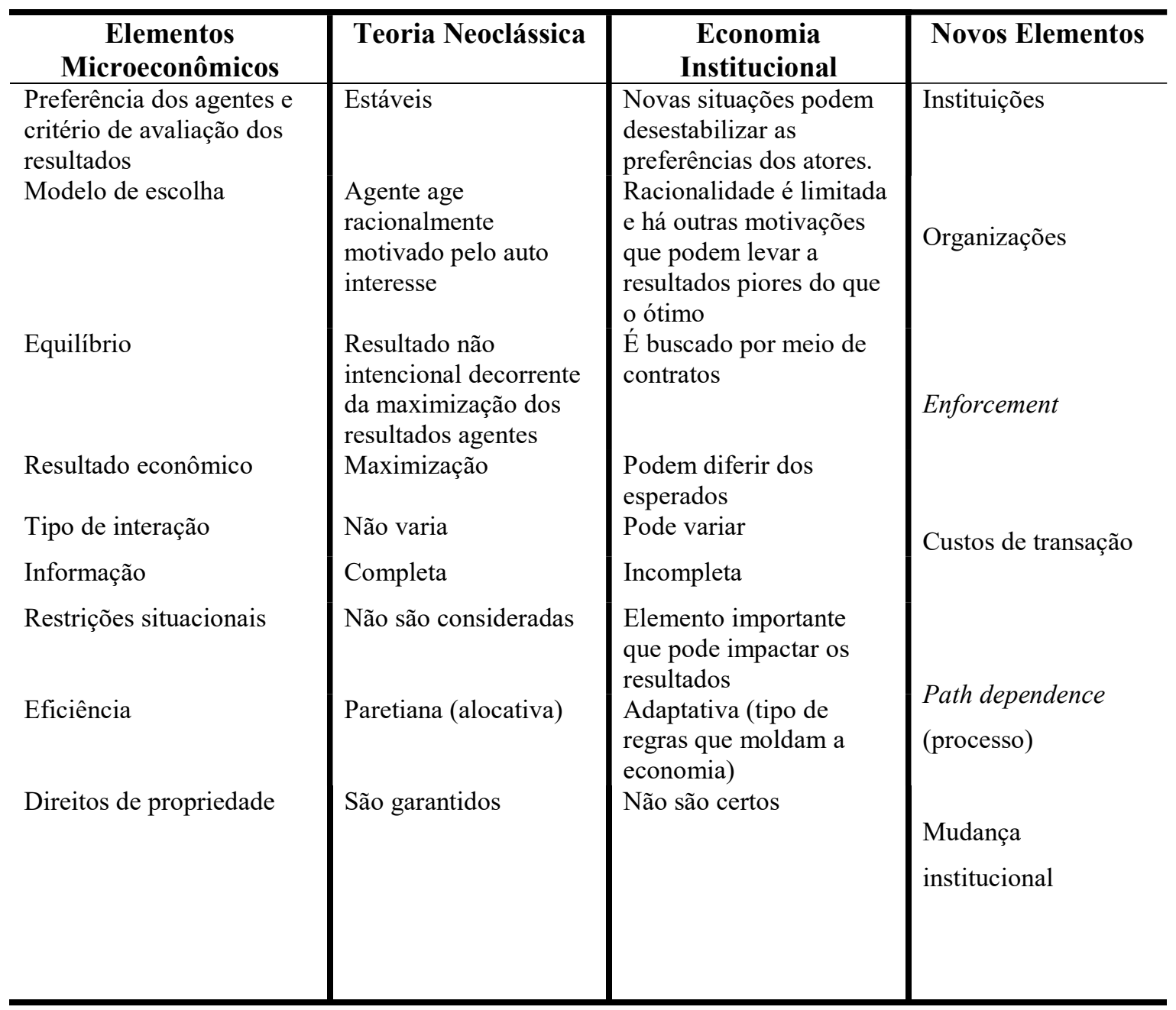

Fonte: Basília Aguirre - Economia Institucional - Material de Aula, Março, 2015.

Uma das dimensões do conceito de instituição é a configuração formal de uma entidade que determine e faça cumprir as normas dentro de uma seqüência hierárquica, o que abrange regras do Legislativo, Executivo, Judiciário ou de agências específicas (Dixit, 2009).

Segundo Pande \& Udry (2005), várias pesquisas cross-country têm evidenciado que a qualidade institucional é uma variável relevante para o crescimento e desempenho econômico de um país. 
Acemoglu, Johnson \& Robinson (2005) afirmam que tanto as instituições econômicas quanto as instituições em geral são endógenas, pois são determinadas, pelo menos em parte, pela sociedade ou por um segmento dela. Por conseguinte, a questão por que algumas sociedades são muito mais pobres do que outras está intimamente relacionada com a questão de por que algumas sociedades têm 'instituições econômicas piores' do que outras.

Selznick (1996) questiona se é adequado traçar uma linha divisória entre o velho e o novo institucionalismo, principalmente porque essa divisão pode inibir contribuições da teoria institucional para questões importantes relacionadas à burocracia e a políticas públicas.

De acordo com Nee (1998), a análise das instituições e seu papel na governança da ação econômica tem sido o problema central endereçado pela Nova Economia Institucional. Nesse sentido ela tem enfatizado o entendimento do papel dos arranjos institucionais formais, tais como os contratos, direitos de propriedade, leis, regulação e o governo.

As leis restringem o livre agir e definem custos e benefícios que serão obtidos das ações delas decorrentes reciprocamente estendidas às ações dos outros. Elas podem ser vistas como contratos constitucionais. A organização do mercado depende das instituições, e nelas incluise o direito de propriedade. A criação das instituições requer mecanismos de enforcement, fundamentais para reduzir a incerteza sobre os direitos legais e garantir a estabilidade social (Buchanan, 1971; North, 1990).

A lei apoiará uma norma de várias maneiras, sendo que a mais óbvia é que ela complementa os mecanismos privados de aplicação com a força do Estado, uma vez que o enforcement é caro para o indivíduo. Mas a lei tem seus limites, por exemplo, é sabido que muitos indivíduos não pagam a totalidade dos tributos que deveriam, e quando se tenta executar a lei, sua força é limitada. Na maioria dos casos a lei só pode funcionar como um complemento (e não um substituto) para a aplicação informal da norma. Outro ponto é a clareza, pois a lei tende a definir obrigações muito mais claramente do que as normas informais.

As empresas, como agentes econômicos, têm sua atuação limitada pelas normas do ambiente econômico em que atuam, e também criam suas próprias normas para reger sua interação com seus clientes. Segundo Ropaul (2010), as firmas também têm um papel importante no desenho das normas legais criadas pelo governo. 


\subsubsection{Instituições de governança econômica: direitos de propriedade}

De acordo com Dixit (2009), governança econômica é “a estrutura de funcionamento das instituições legais e sociais que dão suporte às transações econômicas por meio das instituições dos direitos de propriedade, dos contratos e tomando a ação coletiva para prover infraestrutura física e organizacional." Ela é requerida para assegurar três pré-requisitos essenciais das economias de mercado: (i) a segurança dos direitos de propriedade, pois sem isso os indivíduos não teriam incentivos para poupar ou investir; (ii) o enforcement dos contratos, pois sem isso as pessoas evitariam fazer contratos por medo de serem trapaceadas e ganhos mútuos não seriam realizados; (iii) a ação coletiva, pois muitas atividades econômicas privadas dependem tanto de uma provisão adequada de bens públicos quanto do controle de “males” públicos. Um exemplo desse problema é o gerenciamento dos recursos naturais.

Segundo Andrade \& Sahad (2007, apud Grotius, 2004) os homens, não se contentando mais em se alimentar de frutas silvestres, habitar em cavernas e viver nus ou com seus corpos cobertos por cascas de árvores ou peles de animais selvagens, passaram a optar por um gênero de vida mais cômodo. Assim, eclodiram as primeiras disputas entre os indivíduos, e para a preservação da paz a propriedade privada foi institucionalizada como um direito.

A essência da propriedade privada é o direito de excluir terceiros. Se alguém quiser usar a comida, a casa, a terra ou o arado que pertence a um indivíduo, terá que obter sua permissão. A lei confere o poder ao proprietário dos bens para fazer o que lhe aprouver (Cohen, 1927).

A propriedade privada deu ensejo à criação do arcabouço legal dos direitos de propriedade, instituição que, segundo Rodrik (2003), foi fundamental para o desenvolvimento da economia e para a evolução dos negócios, pois possibilitou controlar o risco de transacionar com desconhecidos viabilizando a troca impessoal, que é base do funcionamento dos mercados.

Com relação ao controle dos recursos naturais, Ostrom (1990) discute os problemas relacionados a dois modos de governança frontalmente distintos: o controle de forma centralizada pelos governos de um lado, e a privatização de outro, e então propõe um modelo de governança com base na ação coletiva. À parte questões envolvidas de assimetria informacional, magnitude dos custos de transação e eficácia do sistema de sanções, basicamente trata-se de uma grande discussão em torno dos direitos de propriedade. 
De acordo com Barzel (1989), a teoria dos direitos de propriedade preconiza que a precificação de um ativo não poderia prescindir de uma avaliação dos custos de transação direta e indiretamente envolvidos na sua proteção. Os custos de transação diretos referem-se aos recursos alocados pela firma para estabelecer estruturas de governança voltadas para proteger seus ativos contra roubos e fraudes. Os custos de transação indiretos representam as instituições voltadas para coibir os atos ilícitos, estruturadas e mantidas com recursos provenientes de toda a sociedade. Desse modo, o significado econômico dos direitos de propriedade coincide com o conceito teórico de ativo.

North (1990) define direitos de propriedade como os direitos que indivíduos apropriam sobre o seu próprio trabalho, bens e serviços que possuem. A apropriação é uma função da estrutura institucional formada por regras legais e seu enforcement, normas de comportamento e formas organizacionais.

Para Littleton (1927), ao se buscar entender os elementos a partir dos quais se deu a criação das partidas dobradas, percebe-se que a contabilidade sempre esteve muito próxima de campos correlatos e nesse sentido, seu desenvolvimento acompanha a evolução da sociedade. Entre esses elementos destaca-se o surgimento da propriedade privada acompanhada do direito de alterar o seu owner, uma vez que registrar o direito de propriedade é o principal objetivo da contabilidade.

Para Shubik (2011), a própria contabilidade societária pode ser vista como um produto oferecido à sociedade decorrente da junção de princípios econômicos e formas legais de comercialização, que estabelecem e delimitam os direitos entre as partes.

Segundo Mattessich (2008), no início do século XX o economista Pawel Ciompa já olhava a contabilidade através do prisma da propriedade, capital e eficiência, sustentando uma abordagem management-oriented da contabilidade que foca sobre a mensuração do desempenho econômico para a tomada de decisão.

Para Guerreiro et al (2006), além de prover os meios para representar o desempenho, as regras e os procedimentos contábeis também definem os direitos dos grupos de indivíduos (donos, financiadores, gestores, trabalhadores etc.) e estabelecem as diretrizes para a alocação de recursos, decisões operacionais, decisões de preços etc. Nesse contexto, mais do que adotar os preceitos da teoria convencional para gerar informações para a tomada de decisões racionais para a maximização do lucro, pode ser explorada a extensão com que a Contabilidade Gerencial pode prover uma base institucional para a tomada de decisões e estruturar a formação de crenças e expectativas. 
Segundo Demsetz (1964), o desenvolvimento dos direitos de propriedade veio acompanhado do desenvolvimento do enforcement legal, que representa o conjunto de instituições criadas para proteger e fazer valer os primeiros. Assim, o nível de proteção dos direitos de propriedade está associado ao nível de eficiência e eficácia das instituições de enforcement legal.

\subsubsection{Análise econômica dos direitos de propriedade (Barzel,1989)}

O termo 'direitos de propriedade' carrega dois significados distintos na literatura econômica: o econômico, relacionado à habilidade de um indivíduo de desfrutar de uma propriedade, e o legal, que é o direito que o Estado atribui a uma pessoa. Nesse sentido, os direitos econômicos são o fim, o que as pessoas buscam em última instância, e os direitos legais são os meios para atingir o fim.

Um indivíduo tem menos direitos sobre um bem que é propenso ao roubo ou a restrições para sua troca. Desse modo, os direitos econômicos que as pessoas têm sobre seus ativos não são constantes, mas uma função: (i) dos seus próprios esforços para protegê-los das tentativas de captura por outras pessoas; (ii) da proteção não governamental formal e informal; e (iii) da proteção governamental primariamente efetuada pelas instituições da polícia e da justiça.

O conceito de direitos de propriedade é estritamente relacionado com o de custos de transação. Assume-se que tanto a proteção, quanto a transferência completa dos direitos são proibitivamente caros, daí os direitos nunca serem completos, porque as pessoas nunca acharão que vale a pena ganhar todo o potencial de seus ativos. Para que os direitos sobre um ativo sejam completos ou perfeitamente delimitados, o seu proprietário, bem como os outros indivíduos potencialmente nele interessados, precisam possuir conhecimento completo de todos os seus atributos valoráveis. Assim, o valor de um ativo é reduzido quando não proprietários são inclinados e hábeis para afetar seu fluxo de resultados.

Um caso de grande importância para o entendimento das circunstâncias sob as quais a propriedade pode ser assegurada surge quando somente uma das duas partes envolvidas pode afetar o fluxo da receita. A responsabilização do indivíduo que afetou o fluxo assegura que a propriedade se torne protegida. Ao proprietário nominal do ativo é conferido o direito à receita que o mesmo pode gerar. A receita líquida que um ativo poderá gerar depende da delineação de direitos, isto é, do quão assegurados estão os direitos sobre esse ativo. A venda 
de ativos e a respectiva obtenção de renda requer uma troca mútua de direitos. Contratos que delineiam os termos sob os quais os direitos legais são trocados governam boa parte dessa troca dos direitos de propriedade econômicos. No limite, indivíduos interagem com outros indivíduos, independentemente se uma ou ambas as partes representam organizações.

A premissa de que os indivíduos são maximizadores do valor dos seus direitos econômicos é útil não só diretamente na análise do comportamento individual, mas também indiretamente como a premissa que sublinha o funcionamento das organizações e de toda a sociedade. A maximização individual implica que sempre que indivíduos percebem que certas ações irão melhorar o valor de seus direitos, eles irão empreender essas ações. Isso sempre se aplica independente se os indivíduos operam em mercados, firmas, famílias, tribos, governo, ou qualquer outra organização.

O modelo walrasiano, do qual deriva a teoria dos preços, inclui os usuários, os bens e os preços, e pode ser estendido para incluir a produção pelas firmas. Nesse mundo o custo da informação é zero, os direitos de propriedade são bem definidos e garantidos sem custo, e as firmas não importam, pois, os indivíduos podem fazer o que as firmas fazem ao mesmo custo. Não há roubo entre as partes que negociam nem incerteza sobre as características ou preço dos bens.

Nesse modelo a firma precisa alocar um equipamento indispensável para produzir seu resultado, mas não é necessário que ele pertença à firma. A propriedade per se não importa. Isso significa que a função de produção não irá especificar quais insumos de capital serão da firma. A função de produção é uma descrição de como os inputs se relacionam com os outputs, mas sua simplicidade vem à custa da organização e do monitoramento, fatores relacionados à propriedade.

A produção é eficiente quando os custos totais - incluindo os custos de transação e os custos gerenciais - são iguais tanto para comprar quanto para produzir. A vantagem dessa estrutura, que permite comparar os custos de utilizar o mercado e de monitorar a produção dentro da firma, está em reconhecer a importância de fatores como a contabilidade, os custos legais, os custos de agência, o tempo gasto com o monitoramento dos trabalhadores, e as despesas para verificar as características dos bens comprados de outras firmas. 


\subsubsection{Direitos de propriedade, custos de transação e externalidades}

Os custos relacionados às negociações empreendidas, ao desenho dos contratos, às inspeções a serem feitas e às providências a serem tomadas para resolver disputas ficaram conhecidos como custos de transação, e sua existência implica que métodos de coordenação alternativos ao mercado, que são dispendiosos e imperfeitos em vários aspectos, podem, no entanto, ser preferíveis ao mecanismo de fixação de preços, que é o único método de coordenação normalmente analisado pelos economistas. O objetivo de evitar esses custos através do mercado poderia explicar a existência da empresa na qual a alocação de fatores surgiu como resultado de decisões administrativas (Coase, 1991).

Custos de transação são os recursos para estabelecer e manter os direitos econômicos de propriedade. Se esses custos são zero, então os direitos de propriedade estão perfeitamente estabelecidos e mantidos. Em face de custos de transação positivos emergem os requerentes residuais para que os ativos sejam usados eficientemente. Colocado de outro modo, os agentes econômicos só se comportarão de modo eficiente se eles ostentarem os custos ou receberem os benefícios de suas ações. Firmas grandes podem garantir um número maior de transações por unidade monetária de capital próprio, mas a um alto custo de monitoramento.

Segundo Kim \& Mahoney (2005), no artigo de 1960, The Social Cost, o argumento teórico de Coase é que as externalidades tanto positivas quanto negativas impedem que as transações no mercado ocorram de modo eficiente devido aos elevados custos de transação para delimitar os direitos privados de propriedade de modo perfeito.

Afirma Alchian (1965) que:

The rights of individuals to the use of resources (property rights) in any society are to be construed as supported by the force of etiquette, social custom, ostracism, and formal legally enacted laws supported by the state's power of violence or punishment. Many of the constraints on the use of what we call private property rights involve the force of the etiquette and ostracism. The level of noise, the kind of clothes to wear, our intrusion on other people's privacy are restricted not merely by laws backed by the police force, but by social acceptance, reciprocity and voluntary social ostracism for violators of accepted codes of conduct. [...] Obviously there is heated dispute as to which forms of behavior should be 'enforced' by social voluntary ostracism and which by formal state's police action.

Os direitos de propriedade internalizam as externalidades quando os ganhos da internalização se tornam maiores do que os custos associados. Esses ajustes surgiram nas sociedades ocidentais em grande parte como resultado de mudanças graduais nos costumes sociais e common law precedentes. A cada passo desse processo de ajustes, é improvável que as externalidades tenham sido conscientemente relacionadas às questões que iam sendo 
resolvidas. Embora esses experimentos legais e morais possam ser procedimentos por tentativa e erro em alguma extensão, numa sociedade que valoriza a busca constante da eficiência, sua viabilidade no longo prazo dependerá de como esses ajustes mudam o comportamento para acomodar as externalidades associadas com mudanças importantes em tecnologia ou valores de mercado (Demsetz, 1964).

Libecap (2016), explica que a principal contribuição do trabalho de Coase (1960), consiste em criticar as soluções "clássicas" providas pela economia para as externalidades envolvendo o meio ambiente, quais sejam, a regulação governamental e a cobrança de taxas, porque as mesmas interferem arbitrariamente na alocação dos direitos de propriedade e podem não maximizar o bem-estar econômico. Alternativamente, Coase propõe que a maximização do bem-estar econômico seria obtida por meio da comparação do produto social total produzido pelas diversas alternativas de arranjos sociais disponíveis em termos de benefícios líquidos dos custos de transação, ou seja, estabelecendo cenários de negociação. Assim, a solução coaseana remete à consideração de quais tipos de instituições poderiam reduzir os custos de definir e executar os direitos de propriedade formais e informais.

\subsubsection{Direitos de propriedade e enforcement legal}

A troca de bens e a manutenção do controle sobre o seu uso impõe custos para os comerciantes e proprietários. Uma questão relevante é avaliar sua importância e o papel que esses custos exercem na vida econômica. Há situações nas quais a negociação direta entre indivíduos envolve custos de troca que são maiores do que os benefícios provenientes da troca. Adicionalmente, há situações em que o custo de policiar os efeitos das ações é tão alto que causa complicações adicionais (Demsetz, 1964).

Uma análise atenta do mecanismo de preços nos mostra que o valor do que está sendo transacionado depende crucialmente dos direitos de ação sobre o bem físico e de como esses direitos são legalmente protegidos. Assim, o enforcement que acompanha os direitos de propriedade tem papel relevante sobre a habilidade dos preços em mensurar os benefícios obtidos a partir da negociação. No caso dos bens públicos ou comuns, os preços, que refletem os benefícios privados, falham ao mensurar a extensão do benefício social derivado (Demsetz, 1964).

Como um caso especial dessa proposição geral, se assumimos que não há custos para policiar os direitos de propriedade, então existe uma relação direta entre o nível em que os 
benefícios privados se aproximam dos benefícios sociais e o nível em que os direitos de propriedade transferidos são 'enforçados'. Por exemplo: para qualquer definição dos direitos que acompanham a propriedade de um automóvel, o mecanismo de preços irá racionalizar o seu estoque existente, mas o valor total desse estoque privado irá depender do nível em que o roubo de automóveis pode ser reduzido devido às leis vigentes e à atuação da polícia (Demsetz, 1964).

Naturalmente, é necessário economizar o custo do enforcement, de modo que nem sempre queremos garantir o controle total ao comprador. Mas, aparte este aspecto, é essencial notar que o poder de avaliação da instituição de propriedade é mais eficaz quando o bem é privado.

Quando as instituições responsáveis por aplicar a lei são fracas, um choque positivo no valor dos recursos naturais pode aumentar a demanda por proteção privada e oportunidades de apropriação por extorsão, favorecendo o surgimento de organizações de tipo mafioso especializadas em tais atividades. Buonanno, Durante \& Prarolo (2012) testaram esta hipótese investigando o surgimento da máfia nos municípios sicilianos do século XIX, onde a falta de execução de direitos de propriedade do estado coincidiu com um aumento acentuado da demanda internacional de enxofre, a mercadoria de exportação mais valiosa da Sicília. Os autores encontraram evidências robustas de maior atividade mafiosa em municípios com maior disponibilidade de enxofre.

Nas sociedades modernas o Estado desempenha o papel de instituição de enforcement. No entanto, nos países em desenvolvimento, a interpretação e a imposição da lei geralmente dependem dos interesses do governo ou do juiz encarregado, o que cria uma grande incerteza. A confiança é essencial para encorajar o cumprimento voluntário na ausência de instituições fortes que possam impor regras formais. Para criar confiança, particularmente em uma situação de enforcement fraco, é necessário que as partes se envolvam em transações mutuamente benéficas durante um período prolongado de tempo (Manzetti \& Rufin, 2006).

Tanto a abordagem normativa quanto a positiva tendem a tomar o enforcement legal como dado, e por isso não tem incluído análises sistemáticas do custo do enforcement para diferentes tipos de leis. A sociedade (ou um indivíduo) compra uma quantidade de enforcement que considera apropriada a determinado código legal. Mais será comprado se o código servir a uma meta de maior valor, por exemplo, proteção contra assassinato, ou se o custo de aumentar o enforcement for menos caro. O nível de enforcement dependerá da variedade de fatores em adição ao esforço (por exemplo, a quantidade de recursos) que uma 
sociedade está preparada para devotar ao enforcement como uma função da quantidade de enforcement que é obtida (Becker \& Stigler, 1974).

Segundo Becker \& Stigler (1974), conforme os ganhos dos violadores aumentam, a qualidade do enforcement tenderia a declinar. Em primeiro lugar, devido à questão do nível de honestidade dos enforcers; em segundo lugar, devido à estrutura de incentivos à honestidade envolvida na sua remuneração. Para um dado suborno, alguns perdoarão, outros processarão. A honestidade dos enforcers dependerá não só da honestidade da população, mas também da quantia gasta para verificar o quão honesta uma dada pessoa é. Por sua vez, a variação nos ganhos dos violadores é frequentemente muito maior do que a dos enforcers.

A qualidade do enforcement também depende do temporal pattern das violações. Subornar ou intimidar enforcers que estariam envolvidos numa violação não repetitiva é mais difícil. Os custos de transação para determinar se a outra parte é confiável são substanciais e tornam-se gerenciáveis para ambos, violadores e enforcers. Essa expectativa de contratos mutuamente lucrativos entre violadores repetitivos e enforcers ajuda a explicar o desenvolvimento do crime organizado: uma organização é engajada mais continuamente em violações que seus membros individualmente. Além disso, pode fazer arranjos com juízes ou com a polícia que não seriam factíveis para seus membros (Becker \& Stigler, 1974).

A seguir apresentamos trabalhos empíricos que buscam evidenciar a efetividade do enforcement legal em face de diversos mecanismos econômicos.

Anderson et al (2009), a partir de estudo de campo no Kenya de fundos financeiros informais denominados 'roscas', mostram que na ausência de mecanismos de enforcement externo as 'roscas' não são sustentáveis, mesmo que o membro que não cumpriu sua obrigação seja excluído de participar de futuras 'roscas'. Esse resultado é importante por não confirmar a assertiva geralmente aceita, de que em grupos informais as sanções sociais são mais efetivas do que o enforcement externo para garantir que seus membros cumpram suas obrigações.

Gray e Deily (1996) investigaram como o enforcement dá suporte ao compliance, e como o compliance influencia a alocação do enforcement em empresas siderúrgicas nos Estados Unidos. Assume-se que a população em geral preferiria ter níveis mais baixos de poluição a um baixo custo. Desse modo, espera-se que os reguladores direcionem mais enforcement para plantas que potencialmente apresentem níveis de aderência ao compliance mais baixos. Os resultados mostraram que as decisões de compliance das empresas siderúrgicas foram afetadas pelas decisões de fiscalização dos órgãos reguladores da poluição 
atmosférica. O enforcement legal aumentou o cumprimento das normas em instalações siderúrgicas.

Segundo Harrison (1995), a abordagem do enforcement adotada pelos órgãos reguladores nos Estados Unidos tende a se apoiar sobre as sanções formais, como penalidades administrativas, civis e criminais. Isso porque esses reguladores definem compliance como lei rígida. Por outro lado, no Canadá é adotada a abordagem cooperativa de enforcement, mais inclinada a negociar escalonamentos de compliance informal com os poluidores, estilo caracterizado como pessoal e amigável entre regulador e regulado, segundo o qual os reguladores interpretam a norma de modo mais flexível, especialmente se há um esforço para se adequar à norma. Buscando levantar que fatores levam os reguladores a adotar o modelo legalista ou o modelo conciliatório na indústria do papel e polpa, e que abordagem é mais efetiva, a pesquisa apontou resultados desapontadores para a abordagem canadense do enforcement comparados à abordagem legalista norte-americana. Desse modo esse estudo levanta dúvidas sobre a premissa relativamente não testada de que o enforcement cooperativo é igualmente, senão mais efetivo que o legalista.

Smith (2004), a partir de uma amostra de 102 países, constatou que o roubo de energia elétrica está aumentando na maioria das regiões do mundo. A pesquisa indicou que os principais fatores relacionados ao fenômeno são os indicadores de governança, com maiores níveis de roubo em países sem responsabilização efetiva, maior instabilidade política, baixa eficácia governamental e altos níveis de corrupção.

\subsubsection{O contrato e a firma}

Nessa subseção apresentamos aspectos econômicos relacionados ao contrato enquanto mecanismo de governança econômica que governa a relação entre concessionária e cliente..

Os contratos são instituições fundamentais para a vida social e econômica no sentido de que representam acordos legalmente executáveis (Lumineau, 2014).

O direito contratual clássico que se iniciou no século XVIII e teve seu apogeu no século XIX apresentou duas características que marcaram todo o pensamento contratual que o sucedeu: (i) sua concepção como um conjunto de poucas regras e princípios simples, abstratos e universais. Tal abstração os tornava independentes de seus contextos institucionais, morais e econômicos específicos; (ii) sua concepção como a fórmula canônica, geral e abstrata de diversas relações sociais. Assim, relações que anteriormente eram vistas em termos de status, 
confiança e dependência econômica (elementos contratuais não promissórios) passaram a ser reinterpretadas do ponto de vista de uma nova concepção de contrato. Esse fenômeno foi descrito por Weber como o "processo de orientação para o mercado da sociedade moderna" (Macedo Jr., 2006).

A teoria das organizações em princípio se destina a esclarecer certas funções e disfunções das economias de propriedade privada partindo de um reexame das transações elementares. Em termos gerais ela representa a intersecção da tradição neoclássica e institucionalista (Granger, 1997).

O programa da Economia dos Custos de Transação ou simplesmente ECT pode ser descrito como o produto de dois campos complementares da pesquisa econômica: a Nova Economia Institucional e a Economia das Organizações, na qual a firma não mais é vista como uma função de produção, mas como uma estrutura de governança (Williamson, 1979; 1998). Na ilustração 3 tentamos sintetizar essas relações.

Ilustração 3. Tradição neoclássica, institucionalista, Teoria das Organizações e ECT

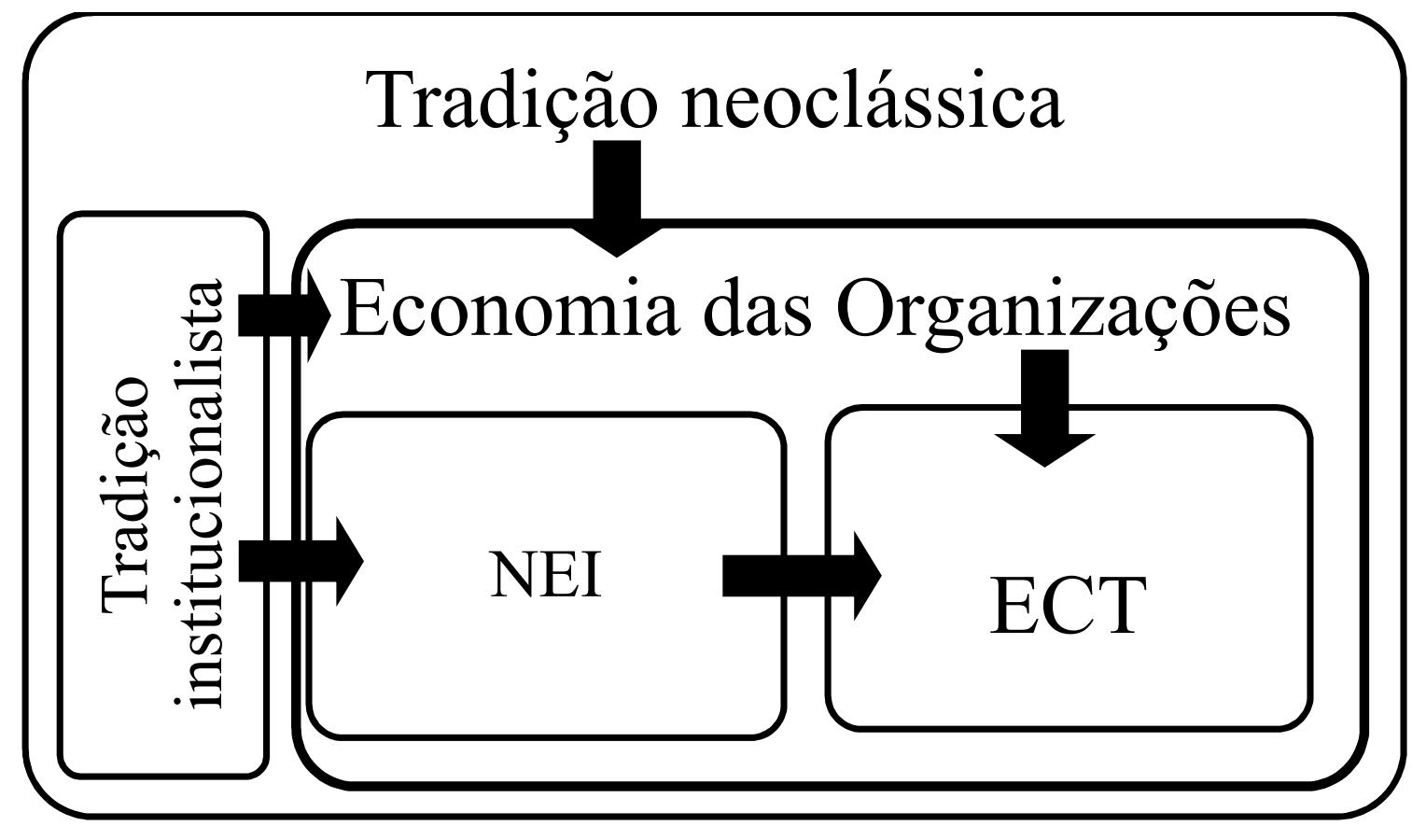

Fonte: a autora

Segundo Posner (2000), as regras da lei contratual, sobre as quais nós temos influência somente quando uma disputa ocorre, são improváveis de terem impacto sobre o comportamento das pessoas. 
Na Economia dos Custos de Transação, ou simplesmente ECT, os contratos são tidos como estruturas de governança desenhados para minimizar os custos de transação (Williamson, 1991).

Se os custos de negociação forem desprezíveis e os usuários afetados puderem negociar livremente uns com os outros, a justiça poderia alocar o direito para qualquer uma das partes sem afetar a eficiência do resultado. $\mathrm{O}$ único efeito da decisão judicial seria quanto à distribuição dos custos e benefícios entre as partes (Coase, 1960).

A hipótese norteadora dessa vertente é que as transações possuem atributos que as diferenciam, e esses atributos devem direcionar a firma para desenvolver a estrutura de governança que melhor se alinhe a eles a fim de minimizar os custos de transação e assim melhorar a eficiência da organização (Williamson, 1985; Alchian, 1988; Gorringe, 1987 Argyres \& Liebeskind, 1999; Bajari \& Tadelis, 2001; Marino, 2005; Rocha \& Guerreiro, 2011).

A natureza da transação é um elemento fundamental que tem que ser considerado na matriz institucional sob a qual as transações serão negociadas e executadas. No entanto ela não identifica claramente as dimensões críticas do contrato nem os propósitos da governança. Não se concebe uma relação contratual sem instituições estabilizadoras, regras sociais, valores, economia e linguagem. Portanto, não existe contrato fora do contexto de uma dada matriz social que lhe dá significado, onde está incluído o mercado. Neste sentido, a sociedade é a fonte primária do contrato (Macneil, 1987).

\subsubsection{Conclusão}

Nas sociedades capitalistas as instituições políticas determinam as regras por meio das leis e normas formais, e as instituições de governança econômica proveem os meios para 'fazer valer' essas regras. Entretanto, para que as últimas possam atingir seus propósitos, a sociedade terá que arcar com custos de transação, que podem assumir vários níveis a depender do quanto as normas formais são legitimadas e subsidiadas pelas normas informais ou sociais. Assim, se as normas informais tiverem seu alicerce em conceitos éticos de direitos e deveres, então os custos de transação demandados pelas instituições de governança econômica para amparar os negócios serão menores e, consequentemente, a eficiência econômica será maior. 


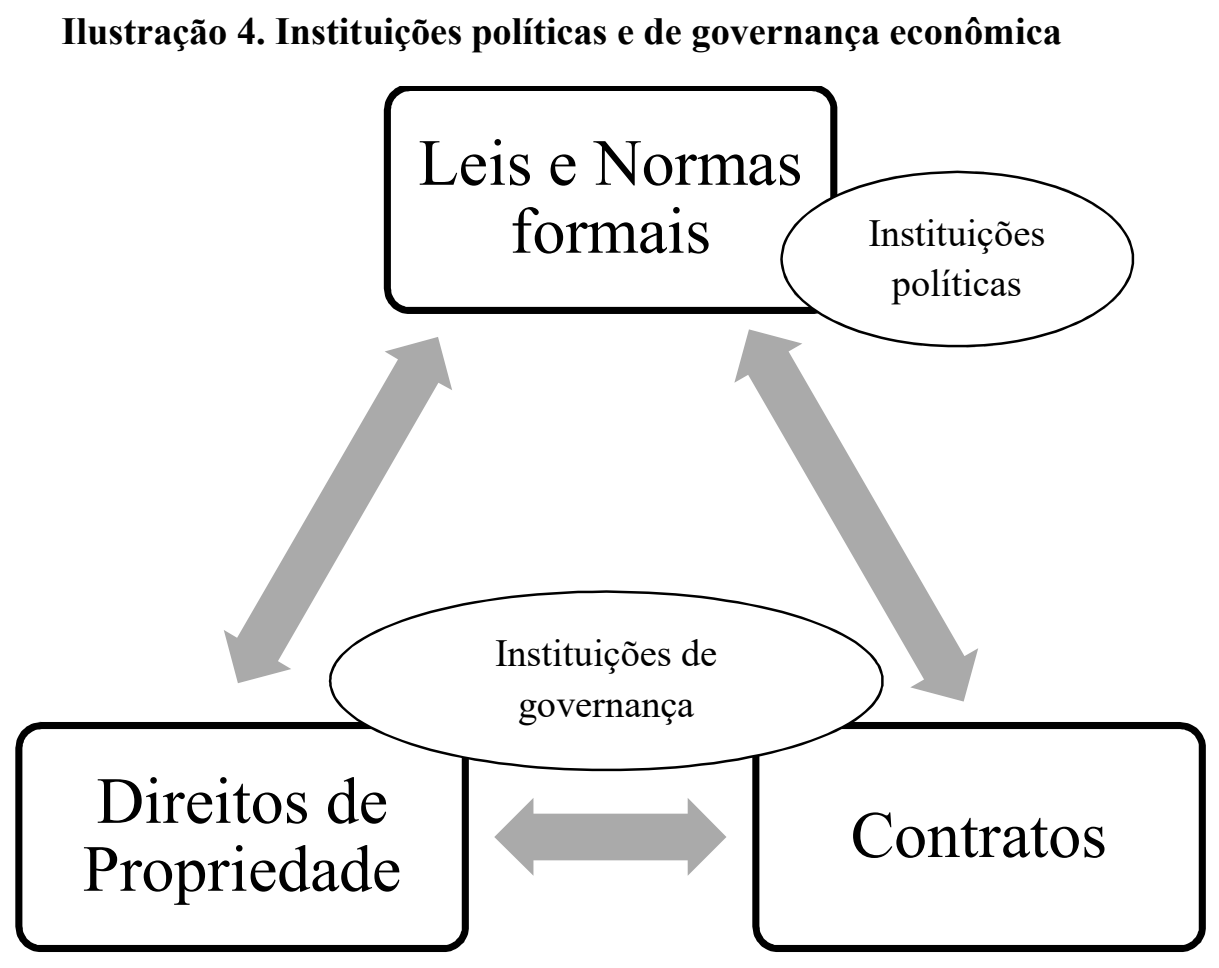

Fonte: a autora

Os atos ilícitos, por sua vez, podem ser originados basicamente pela ausência de condições do indivíduo se enquadrar nas normas legais, ou pela percepção do indivíduo de que há situações em que os custos de transação envolvidos são tão elevados que o risco de cometer o ato ilícito vale a pena, pois a probabilidade de ser pego é muito pequena, ou ainda, no caso de ser pego, o benefício econômico pessoal auferido será maior do que o custo, incluindo o potencial custo social de, por exemplo, perda da reputação e rejeição pelo grupo. Se isso ocorre, uma explicação possível é que alguns valores sociais estão enfraquecidos, ou perderam o sentido per se.

Nesse contexto, um desafio que se apresenta seria traçar uma linha divisória entre os indivíduos que se enquadram na primeira categoria, ou aqueles excluídos de direitos, incluindo o direito de nortear suas próprias vidas por princípios éticos; e os que se enquadram na segunda categoria, ou aqueles cujas ações ignoram os princípios éticos. A primeira categoria está associada às instituições políticas que definiram os direitos de propriedade. A solução é complexa, pois demanda uma mudança institucional. A segunda categoria está associada ao monitoramento dos direitos de propriedade. Nesse caso a solução passa pelo aumento da eficácia dos mecanismos de monitoramento já utilizados, sem, entretanto onerar os custos de transação já incorridos. Esse estudo busca contribuir nesse sentido. 
Tanto a abordagem normativa quanto a positiva tendem a tomar o enforcement legal como dado. No entanto, ele tem papel relevante sobre a habilidade dos preços em mensurar os benefícios privados obtidos a partir da negociação, mas essa mensuração não captura a extensão do benefício social quando se trata de bens públicos ou comuns, como é o caso da água.

Estudos têm fornecido evidências da efetividade do enforcement legal para dar suporte às transações econômicas em vários contextos. Com relação ao fenômeno estudado, as fraudes no setor de água, ressaltamos estudos que relacionam violações repetidas no tempo ao crime organizado, e estudos que relacionam níveis mais elevados de roubo de energia elétrica a níveis baixos de responsabilização efetiva.

Não é possível banir completamente a atividade ilegal da sociedade, não importa a que custo, a menos que a sociedade priorize essa meta em detrimento de outras. Assim, um enforcement mais efetivo da lei serviria para aumentar os ganhos potenciais, por um lado, e por outro a firma teria que buscar mecanismos que aumentassem a eficácia do seu monitoramento, mecanismos esses que deveriam ter um baixo custo incremental, e, portanto, teriam que estar associados a normas e valores sociais, caso esses sejam embasados por conceitos éticos.

Da Nova Economia Institucional a ECT incorpora a visão de que os atores econômicos são racionais na intenção, mas limitados cognitivamente. Nesse sentido, há duas formas de economizar e melhorar a eficiência: atuando sobre o processo de decisão e melhorando a coordenação entre a natureza da transação e as estruturas que a governam. Nesse caso, o papel do gestor tem grande importância, pois ele é o responsável direto pelo enforcement das regras contratuais e empresariais.

\subsection{A ação social}

O uso do conceito da norma é importante para descrever como as sociedades funcionam, principalmente no caso de sociedades tradicionalmente estáveis, pois dão o significado de 'dever' ou de 'comportamento de acordo com as normas aceitas', pois a estabilidade ou a mudança lenta das normas constituem um componente importante da estabilidade dos mecanismos de auto governança da sociedade (Coleman, 1990).

Normas formais são produzidas e enforced por organizações como o governo e a firma para resolver problemas de ação coletiva através de sanções aplicadas por uma terceira parte, 
enquanto normas informais surgem a partir de redes e são reforçadas por meio das relações sociais contínuas. $\mathrm{Na}$ medida em que as normas formais estão em consonância com as preferências e interesses dos atores organizacionais, os processos informais e de controle social reduzem em grande parte os custos de monitoramento e de fiscalização, o que permite reduzir os custos de transação e alavancar o desempenho econômico e organizacional (Nee, 1998).

Em algumas situações, comprometimentos de longo prazo podem ser obtidos com base em investimentos modestos em monitoramento e mecanismos de sanção e normas compartilhadas que reduzem o custo de monitoramento (Adger, 2003; Rudd, 2000).

Na política, os direitos e as liberdades civis são protegidos tanto por normas informais quanto pelo poder do sistema legal formal. Mas para além das questões políticas, as normas são vitais para outras ciências sociais, como a Sociologia, para compreender como diferentes sociedades funcionam e para a Antropologia, que lida com as características únicas de vários povos, descrevendo em detalhes as suas práticas e valores. Os psicólogos se preocupam com a forma como as pessoas se influenciam mutuamente e com a maneira pela qual um indivíduo se torna socializado em uma comunidade. Por sua vez, os economistas concluíram que o mercado em grande parte se comporta com base nas normas que nenhum indivíduo pode determinar sozinho (Axelrod, 1986).

Os três tipos mais comuns de definições da norma são baseados em expectativas, valores e comportamento, o que sugere que esses três itens estão interligados. A norma existe num determinado contexto social, na medida em que os indivíduos costumam agir de uma determinada maneira e podem ser punidos quando é visto que não estão agindo conforme o esperado (Axelrod, 1986).

As normas atuam como um poderoso mecanismo de regulação de conflitos e governam grande parte da nossa vida política e social (Axelrod, 1984; Dixit, 2009). Enquanto as instituições formais possuem aparato legal e poder de coerção, as normas informais se autogovernam, usando estratégias disponíveis aos participantes em sua interação econômica. As leis, políticas de governo e normas regulatórias fazem parte do primeiro grupo enquanto as redes sociais, as normas de comportamento e respectivas sanções sociais por violá-las, e os arranjos privados com e sem finalidade lucrativa fazem parte do segundo. 


\subsubsection{A teoria da ação social (Coleman, 1986; 1990}

Normas são constructos sociais que se baseiam em ações intencionais no nível individual. As normas geralmente conduzem para sanções ou ameaças de sanções que afetam a utilidade das ações dos indivíduos para os quais as sanções deverão ser aplicadas.

Para a emergência das normas duas condições assumidas em conjunto são suficientes: a primeira é a condição sob a qual surge uma demanda por uma norma efetiva. A segunda é a condição sob a qual essa demanda será satisfeita. A existência de normas pressupõe a necessidade de sanções correspondentes, que pelo menos no contexto da teoria social é considerado como uma afirmação axiomática. Normas são ordinariamente 'enforçadas' por punições para ações vistas como incorretas. As punições previstas afetam as decisões dos indivíduos ao planejarem suas ações. Aqueles que subscrevem uma norma demandam o direito de aplicar sanções e reconhecem o direito de outros subscreverem as normas para isso.

A definição explícita da norma é importante porque ela deriva do conceito de direitos. Uma norma que concerne a uma ação específica existe quando o direito socialmente definido para controlar a ação não é do ator, mas de terceiros, o que significa que terceiros possuem autoridade sobre a ação, autoridade que é criada pelo consenso social que coloca o direito em suas mãos. O direito que é relevante para a definição de uma norma trata-se de um direito socialmente definido que pode existir mesmo na ausência de um direito legalmente definido ou em oposição a um direito legalmente definido, como no caso de uma norma que está em conflito com a lei.

Uma norma existe somente quando outros assumem o direito de afetar a direção da ação que um indivíduo irá tomar. Além disso, ela pode estar incorporada num sistema social de um modo mais fundamental: uma norma é dita internalizada no indivíduo que toma a ação quando ele se auto censura ou mira a recompensa social pelo seu comportamento aderente.

Outro fator relacionado às duas condições fundamentais para o surgimento de normas efetivas é a especificação de quem irá sustentar a norma e determinar a força e prevalência de sanções, reconhecendo que sua aplicação pode implicar em custos para o sancionador. Finalmente, outro ponto é determinar os tipos de sanções que serão aplicadas, se aquelas que atingem a reputação ou as que impõem danos físicos ou materiais.

Quando uma ação tem consequências externas sobre atores que não possuem nenhum controle sobre ela dizemos que ela gera externalidades, que podem ser positivas ou negativas a depender se geram benefícios ou malefícios. Se uma ação produz externalidades negativas 
surge o problema de como e o quanto limitá-la. Se por outro lado produz externalidades positivas, o problema consiste em como e em quanto encorajá-la.

Quando uma ação gera externalidades para outros indivíduos, uma solução possível seria a proposta por Coase (The Problem of Social Cost, 1960): a negociação de direitos de controle, na qual os atores que não detém controle da ação devem comprar direitos de controle daqueles que os detém, e a única limitação para a ação dos primeiros seria seu interesse e recursos para fazê-lo. Nesse caso, na ausência de custos de transação o resultado seria um ótimo social. No caso de um bem público, cada ator beneficiado pelas ações de outros negociaria direitos de controle de sua própria ação por direitos de controle parcial sobre as ações de cada um dos demais. Por exemplo, cada morador de uma cidade deveria concordar com a construção de um parque público e contribuir com uma fração do custo. Isso constitui uma troca multilateral na qual cada um renuncia ao direito de não contribuir em troca dos outros abrirem mão do mesmo direito.

A condição sob a qual se cria a demanda para uma norma surge quando uma ação tem externalidades similares para um grupo, mas a troca de direitos de controle sobre a ação não pode ser facilmente estabelecida. Sendo assim, nenhum ator pode se engajar lucrativamente numa troca para ganhar direitos de controle. Esses interesses criam uma demanda para uma norma sobre a parte daqueles que experimentam certas externalidades. Assim, a genesis de uma norma é baseada em externalidades de uma ação que não pode ser superada por simples transações que colocariam o controle da ação nas mãos daqueles que experimentam as externalidades.

Normas de etiqueta são essenciais, pois restringem o alvo do ator, que foca os interesses daqueles que interagem com ele, e ao mesmo tempo criam um status para os membros que compõem o grupo. Agir em conformidade com uma norma de etiqueta cria uma externalidade positiva para os membros do grupo (status) pela sua diferenciação com relação aos demais que não pertencem ao grupo. A norma não promoverá uma externalidade positiva para os membros do grupo a menos que agir em conformidade com a norma imponha dificuldades suficientes para não possibilitar facilmente a entrada de terceiros no grupo.

Três evidências de como as sanções são aplicadas na sociedade são:

1. Numa comunidade pessoas influentes não somente têm menor probabilidade de sofrer sanções, como também menor probabilidade de obedecer às normas do que as pessoas menos influentes. 
2. Os que estão na base da pirâmide social reclamam menos das normas do que aqueles que estão no topo.

3. Alvos de uma norma que têm contatos com outras pessoas de fora que não são titulares das normas são menos propensos a estar em conformidade com as normas.

\subsubsection{Ação econômica e estrutura social (Granovetter, 1985; 1992; 2005)}

Um problema clássico em teoria social é entender como o comportamento e as instituições são afetadas pelas relações sociais. A concepção oversocialized do homem na moderna sociologia afirma que a socialização torna as pessoas muito sensíveis às opiniões de terceiros e obedientes ao que ditam os sistemas de normas e valores consensualmente desenvolvidos e internalizados, assim que a obediência não é percebida como um fardo. Esse nível exagerado de incorporação ao ambiente é conhecido como embeddedness. Assim, é comum atribuir estilos distintos de tomada de decisão a membros de diferentes classes sociais como resultado ou da cultura da classe, ou da sua experiência ante o sistema educacional. Nesse contexto o comportamento dos atores resulta de suas posições sociais.

A concepção oversocialized de como a sociedade influencia o comportamento individual atua de forma mecânica: uma vez que conhecemos a classe social do indivíduo ou o setor do mercado em que atua, tudo o mais relativo ao seu comportamento é automático.

A economia clássica e neoclássica, em contraste, opera com uma concepção atomizada e undersocialized ou subsocializada da ação humana, continuando a tradição utilitarista. Os argumentos teóricos desautorizam por hipótese qualquer impacto da estrutura social e das relações sociais sobre a produção, a distribuição ou o consumo. Essa visão está associada à premissa do interesse próprio.

No mercado idealizado, que envolve um grande número de vendedores e compradores anônimos guarnecidos com informação perfeita, não há que se falar em relações sociais no sistema de trocas. A solução da economia clássica prescinde de estruturas políticas repressivas para o mercado competitivo, o que torna a força e a fraude inúteis. A competição determina os termos do negócio de modo que os agentes individuais não podem manipular. Se os agentes encontram relações complexas, caracterizadas pela desconfiança ou malfeito, eles podem simplesmente procurar outros agentes que desejam negociar nos termos do mercado. 
Uma análise frutífera das relações humanas precisa evitar a atomização implícita nos extremos teóricos das concepções under e oversocialized. Atores não se comportam ou decidem como átomos fora do contexto social nem aderem com total subordinação a um script escrito pelas categorias sociais às quais pertencem. Suas tentativas de tomar ações propositivas, ao contrário, são envolvidas no presente (ongoing) sistema de relações sociais.

Segundo Maximiliano (1957), a própria vontade humana é condicionada, determinada, livre na aparência apenas. O indivíduo inclina-se de acordo com o seu temperamento, produto do meio, da hereditariedade e da educação.

A pergunta hobbesiana - por que alguém que persegue seu interesse próprio não o faz principalmente pela força ou fraude - encontra duas respostas fundamentais relacionadas aos conceitos de ações humanas super e subsocializadas. A visão da nova economia institucional é que as instituições sociais e os arranjos previamente pensados como resultados de forças legais, históricas, políticas e sociais são vistos como a solução eficiente para certos problemas econômicos. Aqui a prevaricação é evitada porque o arranjo concebido a torna muito custosa, ou seja, o arranjo é concebido para dificultar a transgressão pelos agentes envolvidos. Entretanto, é fundamental notar que o arranjo não produz confiança, mas um substituto funcional para ela. Os principais arranjos são os contratos.

O que erodiu essa confiança nos últimos anos tem sido o aumento da atenção no nível micro para os mercados de competição imperfeita, caracterizados por um pequeno número de participantes com custos afundados e investimentos específicos em capital humano, assim que nessas situações o problema clássico de como evitar que a vida econômica diária seja crivada por desconfiança e malfeitos ressurgiu.

O interesse entre os economistas pelas questões antes negligenciadas da confiança e do malfeito remonta à década de 1970. A busca do auto interesse, segundo Hirschmann (1977), não é uma paixão tipicamente incontrolável, mas uma atividade civilizada. A ampla aceitação dessa ideia de modo implícito é um exemplo de como as concepções under e oversocialized se complementam; atores atomizados em mercados competitivos internalizam esses padrões normativos para garantir a ordem das transações.

Em parte essa premissa persistiu porque num mercado auto regulado as forças competitivas poderiam suprimir força e fraude. Outros economistas reconheceram que assumir algum nível de confiança é necessário para operar, uma vez que os arranjos institucionais sozinhos não podem impedir a força ou a fraude. Mas ainda resta explicar a origem dessa confiança. Sabe-se, contudo, que indivíduos preferem negociar com quem tem 
boa reputação, e que a força e a fraude são mais eficientes se perseguidos por times, e a estrutura desses times requer algum nível de confiança interna.

\subsubsection{Conclusão}

Quando o dever tem significado importante na vida dos indivíduos os mecanismos de auto governança são mais estáveis e com isso a sociedade se torna mais estável, o que propicia uma base sólida para o desenvolvimento econômico. Como as normas pressupõem sanções para o seu não cumprimento, pode-se concluir que nas sociedades mais estáveis as sanções são menos utilizadas, uma vez que as normas atuam como mecanismos de auto governança. Entretanto, se descumprida a norma, a sanção será efetiva.

A norma deriva de um direito socialmente definido. Assim, uma ação irregular terá, além da punição prevista legalmente, também uma sanção prevista socialmente, caso o indivíduo venha a ser responsabilizado. Entretanto, pessoas influentes tem menor probabilidade de sofrer sanções.

A vertente da economia institucional está associada à visão oversocialized da ação individual. Nessa abordagem o agente seria 'constrangido' a negociar dentro da norma, pois prevaricar seria antieconômico, e os mecanismos de governança econômica devem garantir a segurança das transações.

Por sua vez, a vertente neoclássica está associada à visão undersocialized, na qual o indivíduo é movido pelo interesse próprio, e nesse contexto a confiança é um pressuposto, cuja quebra levaria o agente econômico a ser eliminado do jogo competitivo. Nesse contexto a força e a fraude são inúteis, pois para o fraudador a obtenção de um benefício de curto prazo pode se reverter em um malefício de longo prazo. Entretanto, em mercados imperfeitos e que apresentam custos afundados o baixo nível de competição tem concorrido para erodir o nível da confiança. Assim, é lícito concluir que nesse ambiente a abordagem institucional pode ser útil.

A ilustração a seguir sintetiza as principais forças que atuam sobre as fraudes. 
Ilustração 5. Forças que atuam sobre as fraudes

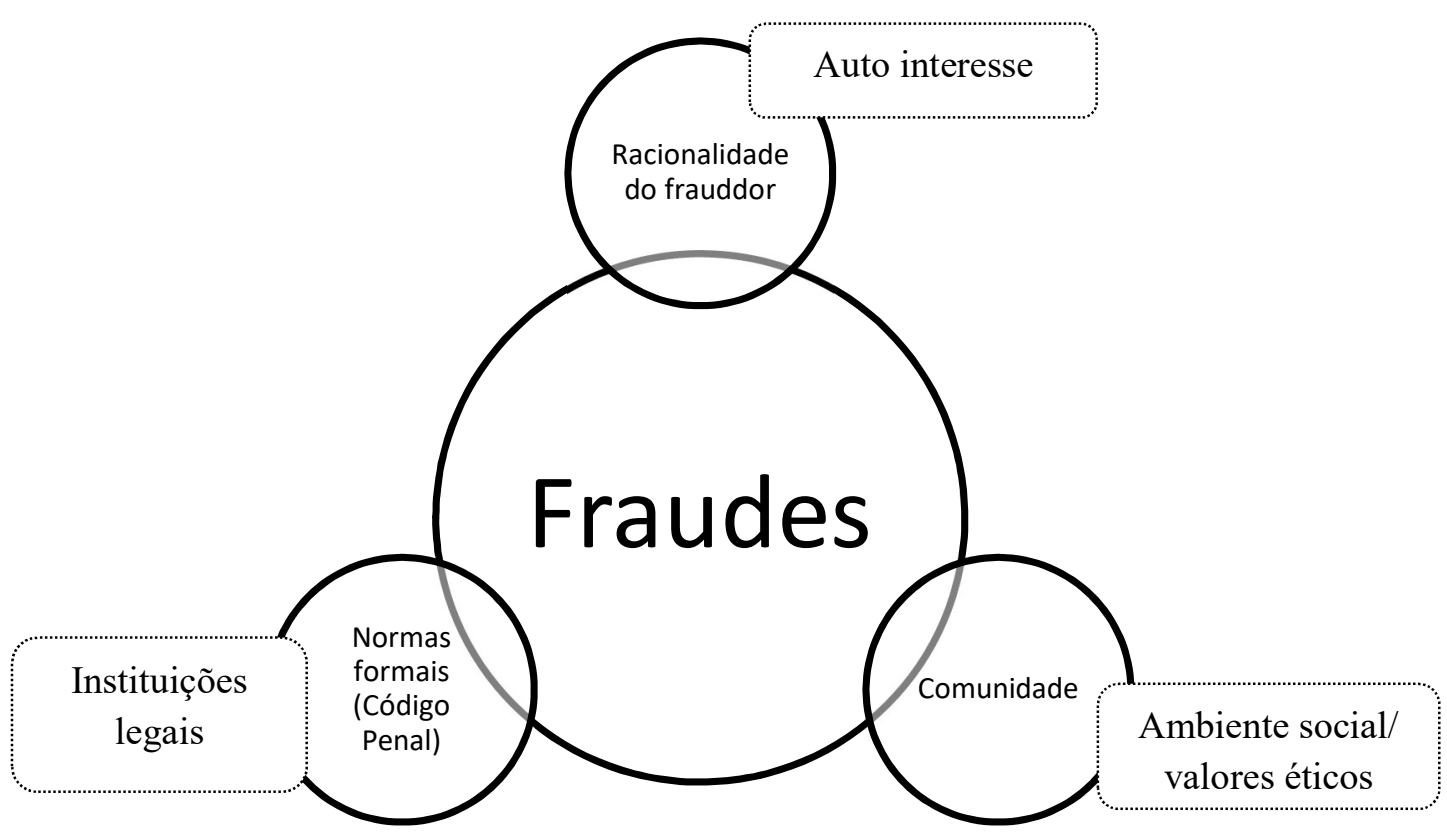

Fonte: a autora

Além da racionalidade do fraudador, outros fatores que influenciam as fraudes são as políticas públicas e a comunidade. 


\section{FRAUDES EM SERVIÇOS DE ÁGUA NA RMSP: ASPECTOS GERAIS}

Neste capítulo apresentamos a Cia de Saneamento Básico do Estado de São Paulo, Sabesp, empresa concessionária dos serviços de abastecimento de água e esgotamento sanitário em diversos municípios do Estado de São Paulo, e na sequência discorremos sobre os mecanismos que a empresa dispõe para monitorar as fraudes dos clientes.

\subsection{Caracterização da empresa}

A Cia de Saneamento Básico do Estado de São Paulo, Sabesp, é uma empresa brasileira de economia mista e capital aberto, cujo principal acionista é o Governo do Estado de São Paulo. Foi instituída pela Lei 119, de 29 de junho de 1973, e tem como missão 'prestar serviços de saneamento, contribuindo para a qualidade de vida e do meio ambiente'. Em junho/2016, por meio de contrato de concessão, atuava diretamente em 379 dos 645 municípios paulistas. Além disso, a Sabesp fornece água no atacado para seis municípios da Região Metropolitana de São Paulo, totalizando um atendimento direto para aproximadamente 28 milhões de pessoas.

Desde 1994 a Sabesp utiliza o modelo de gestão baseado em unidades de negócio regionalizadas com autonomia para administrar seus recursos. A empresa abriu seu capital em 1997 e em 2002, após entrar para o Novo Mercado Bovespa, lançou seus papéis na Bolsa de Valores de Nova York.

O ciclo operacional do saneamento tem início e fim nas fontes naturais de recursos hídricos. No início ocorre o 'saque' da água bruta dessas fontes e no final, efluentes e resíduos sólidos são lançados nas mesmas.

O sistema de abastecimento de água é composto por dois grandes processos: o processo de produção da água tratada e o processo de distribuição e coleta junto ao consumidor final. A água tratada é produzida nos sistemas produtores, complexos que envolvem represas, estruturas - poços, barragens, adutoras e estações elevatórias de água bruta e estações de tratamento de água -, e equipamentos. Em 2016 a RMSP era abastecida com água proveniente de oito sistemas produtores: Guarapiranga, Alto Tietê, Rio Grande, Rio Claro, Alto Cotia, Baixo Cotia, Ribeirão da Estiva e Cantareira.

Uma vez tratada, a água é conduzida para os 'setores de abastecimento', onde fica armazenada em grandes reservatórios de distribuição. Na sequência a água é levada até os 
reservatórios de bairro, de onde segue por adutoras para as redes de distribuição, por meio das quais chega ao consumidor final. Após utilizada, a água cai nas redes coletoras de esgoto, de onde segue para as estações de tratamento de esgoto. Finalmente, o esgoto tratado é reconduzido para os rios.

A seguir apresentamos o organograma geral da Sabesp.

Ilustração 6. Organograma geral da concessionária Sabesp

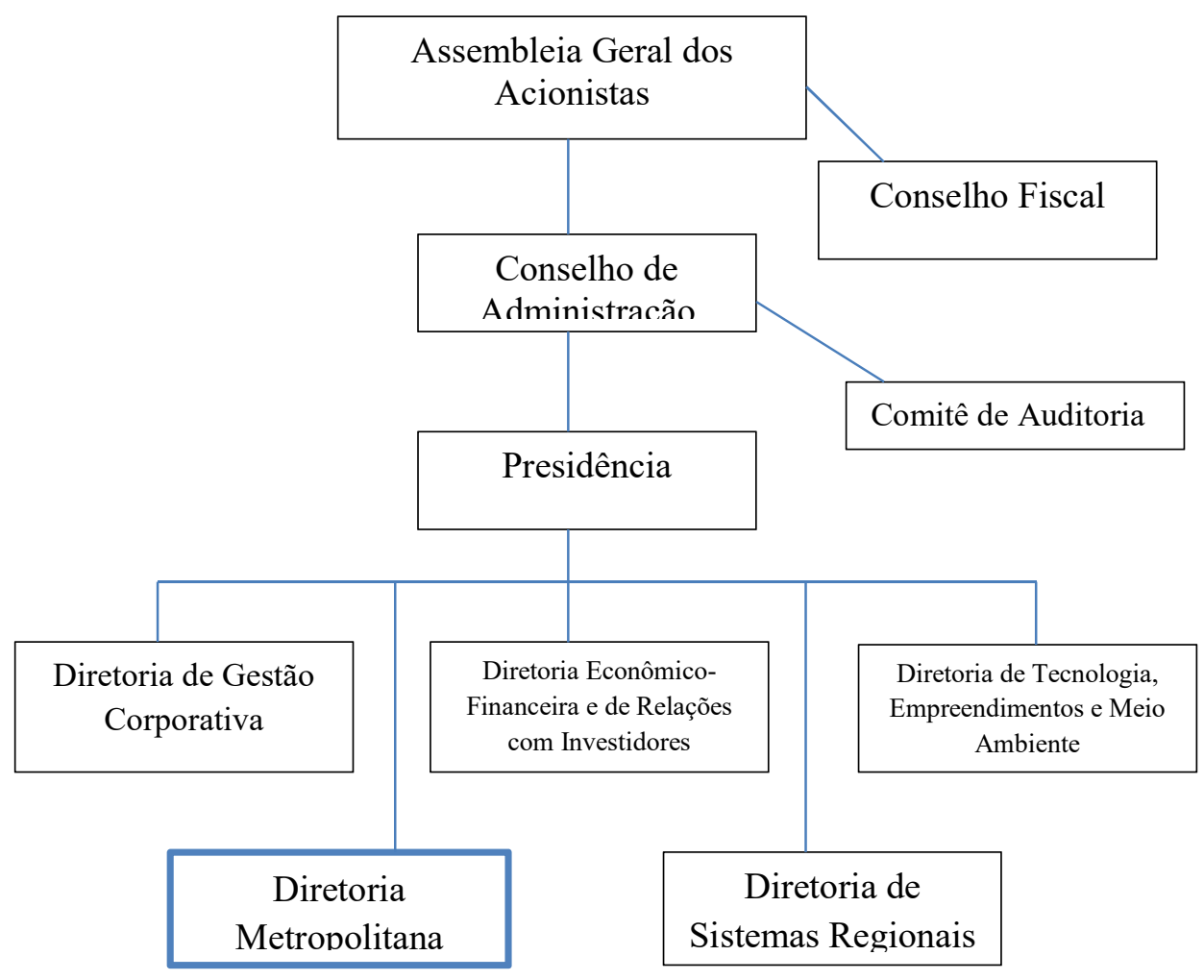

Fonte: Intranet da Sabesp, maio/2018.

Esse trabalho está diretamente relacionado à Diretoria Metropolitana, responsável pelo abastecimento da Região Metropolitana de São Paulo, cujo atendimento é operacionalizado por cinco Unidades de Negócio. A seguir apresentamos o organograma completo da Diretoria Metropolitana. 
Ilustração 7 - Organograma da Diretoria Metropolitana

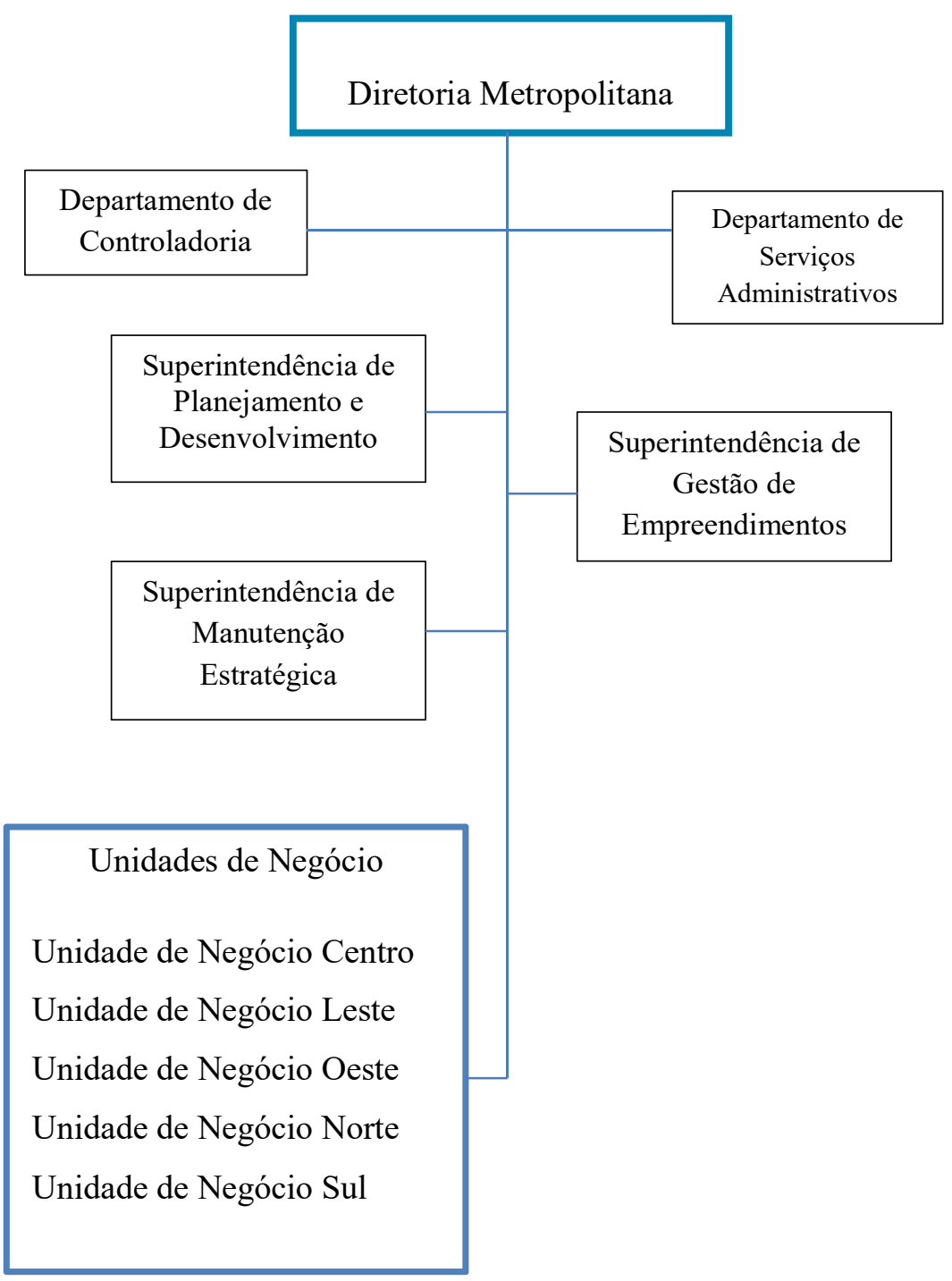

Fonte: Intranet da Sabesp, maio/2018.

\subsection{Fraudes comerciais em serviços públicos}

As fraudes constituem uma perda comercial ou não técnica, pois representam um consumo não faturado.

No setor elétrico as perdas não técnicas durante a transmissão de energia representam um importante problema em países em desenvolvimento, e as empresas que prestam esse serviço tem muita dificuldade para detectar os indivíduos responsáveis pelos roubos (Depuru et al, 2011) . 
Segundo Angelos et al (2011), as concessionárias de energia tentam combater a fraude por meio de inspeções in loco, e esse processo requer um bom planejamento devido ao seu alto custo, que inclui mobilização e treinamento da equipe de especialistas, geralmente terceirizada. Além disso, o treinamento deve ser oferecido de forma contínua, uma vez que diferentes tipos de fraudes estão sendo cada vez mais identificados.

Santos (2011) investigou aspectos éticos na prática de furto de energia elétrica com o objetivo principal de compreender a percepção dos consumidores no que se refere a práticas ilegais no consumo e à inadimplência no pagamento das faturas da concessionária. Os resultados indicaram que embora muitos tenham relatado a prática da fraude como comportamento incorreto, não a censuraram com veemência. Além disso, afirmaram essa prática atualmente seria uma ação comum, verificada tanto em bairros periféricos como nas áreas mais ricas da cidade. Fatores que estimulam essas práticas podem ser agrupados em sociais, pessoais, econômicos e relacionados à ética do consumidor, que não percebe essa prática como imoral e tenta justificar sua prática ilegal relacionando-a ao alto custo dos impostos, ao monopólio da concessionária e à oferta de terceiros.

Francisco et al (2010) desenvolveram um indicador de propensão a perdas comerciais de energia para medir a influência cultural da vizinhança no comportamento do cliente no ato de fraudar.

Winther (2012) examinou qualitativamente o fenômeno do roubo de energia elétrica em países com contextos distintos de desenvolvimento com o objetivo de mostrar os méritos da aplicação de uma abordagem sociotécnica e relacional. Para isso, realizou pesquisa de campo etnográfica em áreas rurais da Zanzibar e Tanzânia, e também nas Ilhas Sunderban e Bengala Ocidental, na Índia. Os resultados apontaram que Zanzibar e as Ilhas Sunderban diferem em termos de estrutura de governança do fornecimento de eletricidade quanto ao uso de tecnologias, organização e procedimentos de medição, faturamento. No entanto, em ambos os locais, a moralidade e o grau de cumprimento das regras pelos clientes estão condicionados por sua relação com o seu fornecedor e pelo sistema sócio-técnico que dá suporte a esta relação. Adicionalmente, os resultados mostraram como o nível de confiança das pessoas em seu fornecedor exerce papel fundamental e interfere nos atos ilícitos.

Khazaee et al (2017) analisaram as perdas numa típica rede de distribuição de média e baixa voltagem no Mashhad e concluíram que as maiores perdas eram não técnicas, que por sua vez tinham como maior fonte as fraudes. 
Para Labate et al (2015), um percentual significativo da energia consumida por usuários fraudadores não seria consumida se eles tivessem que pagar por ela.

Ghajar \& Khalife (2003) analisaram os custos e benefícios da utilização da tecnologia de leitura automática na minimização de vários aspectos relacionados à gestão da energia elétrica no Líbano, inclusive a minimização de fraudes dos clientes.

Passini \& Toledo (2002) avaliaram a utilização da tecnologia de mineração de dados (Data Mining) no setor de saneamento básico com a finalidade de prever fraudes dos clientes. Para a seleção das variáveis foram feitas duas análises. Na primeira, os campos das tabelas foram classificados em três categorias: (i) informações cadastrais ou domiciliares, que variam muito pouco e são específicas do cliente (do tipo endereço e bairro); (ii) informações sobre o relacionamento do cliente com a empresa (do tipo idade da ligação e do hidrômetro, padrão da ligação e vazão do hidrômetro instalado); e (iii) informações sobre o comportamento do cliente ao longo do tempo (do tipo consumo mensal, percentual de variação de consumo a maior e a menor e multas aplicadas). Como o objetivo era achar um padrão de comportamento que identificasse fraudes, para o modelo selecionaram-se as variáveis de comportamento e as demais classificações serviram para ajudar na interpretação dos resultados.

Segundo Araújo (2007), uma grande preocupação das agências reguladoras de energia elétrica brasileiras é propiciar a interação entre os agentes do setor de distribuição de energia elétrica e as autoridades policiais, o Ministério Público e o Poder Judiciário para fortalecer o combate à fraude no consumo e no desvio de energia. Ainda nesse sentido, as agências buscam esclarecer a sociedade sobre os impactos financeiros nas tarifas de energia elétrica decorrentes do consumo irregular.

Nos setores de energia elétrica e água, cujos serviços são difusos, é impossível detectar todas as irregularidades cometidas pelos usuários. Assim, os gestores precisam formular estratégias de modo a criar atalhos entre a empresa e os fraudadores. No setor elétrico as irregularidades vêm sendo investigadas em profundidade há algum tempo. Araújo (2007) seleciona alguns fatores que influenciam a incidência de irregularidades nesse setor. São eles:

- Pouca físcalização, muitas vezes pela dificuldade de acesso à área;

- Impunidade ou falta de respaldo jurídico para punir;

- Facilidade de fraudar / adulterar o medidor;

- Falta de incentivo às denúncias de fraudes, ou de mecanismos para captura-las;

- Falta de inovações tecnológicas voltadas para melhorar o sistema de fiscalização;

- Falta de alternativas para mudar o sistema de faturamento ou as alternativas 
disponíveis tem um custo proibitivo;

- Situação financeira do usuário (pontual ou transitória);

- Situação de alta vulnerabilidade ou pobreza crônica do usuário;

No setor de água os fatores citados também são comuns. Empregados ligados diretamente ao processo voltado para a constatação das irregularidades acrescentam ainda:

- Malícia ou oportunismo por parte do usuário na utilização de regras da agência reguladora ou do Código de Defesa do Consumidor;

- Falta de incentivo financeiro para a mão-de-obra própria dedicada à detecção de fraudes, cuja grade salarial é idêntica à da fiscalização geral de serviços operacionais;

- Falta de mão-de-obra externa especializada na detecção de fraudes no setor de água;

- Falta de interesse por parte dos Distritos Policiais em registrar esse tipo de ocorrência, que concorre com outros tipos de delitos e crimes;

- Corrupção na instituição da Polícia;

- Envolvimento de funcionários da própria empresa ou terceirizados que criam um mercado de fornecimento de mão-de-obra especializada em executar certos tipos mais complexos de irregularidades, e por isso mais difíceis de detectar.

Além desses fatores, com base em Rudd (2000), citamos ainda a ausência de programas estruturantes e perenes voltados para reforçar o relacionamento com as comunidades.

Manzetti \& Rufin (2006) investigaram a dinâmica da fraude e do não pagamento de serviços públicos na Colômbia, República Dominicana e Ecuador, e chegaram à conclusão de que as pressões econômicas enfrentadas pelas famílias pobres locais exercem papel importante nessas questões. Entretanto, o poder de compra por si só não é um bom indicador para esses fenômenos, pois quando os serviços públicos eram providos pelo governo, a falta de pagamento e a fraude resultavam da corrupção e do clientelismo principalmente nas áreas de classe média e média alta, uma vez que a proteção dos direitos de propriedade nesses países é geralmente precária, pois as leis favorecem o governo e os tribunais não têm poder ou vontade para aplicá-las. Assim, sob as premissas de que a fórmula vencedora poderia ser encontrada se as condições de mercado locais fossem compreendidas e endereçadas, e de que o não pagamento e as fraudes poderiam ser significativamente reduzidos mediante abordagens inovadoras para fomentar a cooperação e a confiança envolvendo representantes da comunidade e do governo, algumas empresas fizeram esforços para estabelecer um ambiente 
onde a cooperação voluntária tornasse a necessidade de policiamento para sanções menos necessária.

\subsubsection{Governança das fraudes comerciais na RMSP}

Uma estimativa do impacto das fraudes sobre as perdas de água em termos de volume total faturado da concessionária em questão é apresentada na Ilustração a seguir.

Ilustração 8. Estimativa do impacto das fraudes em termos de volume não faturado

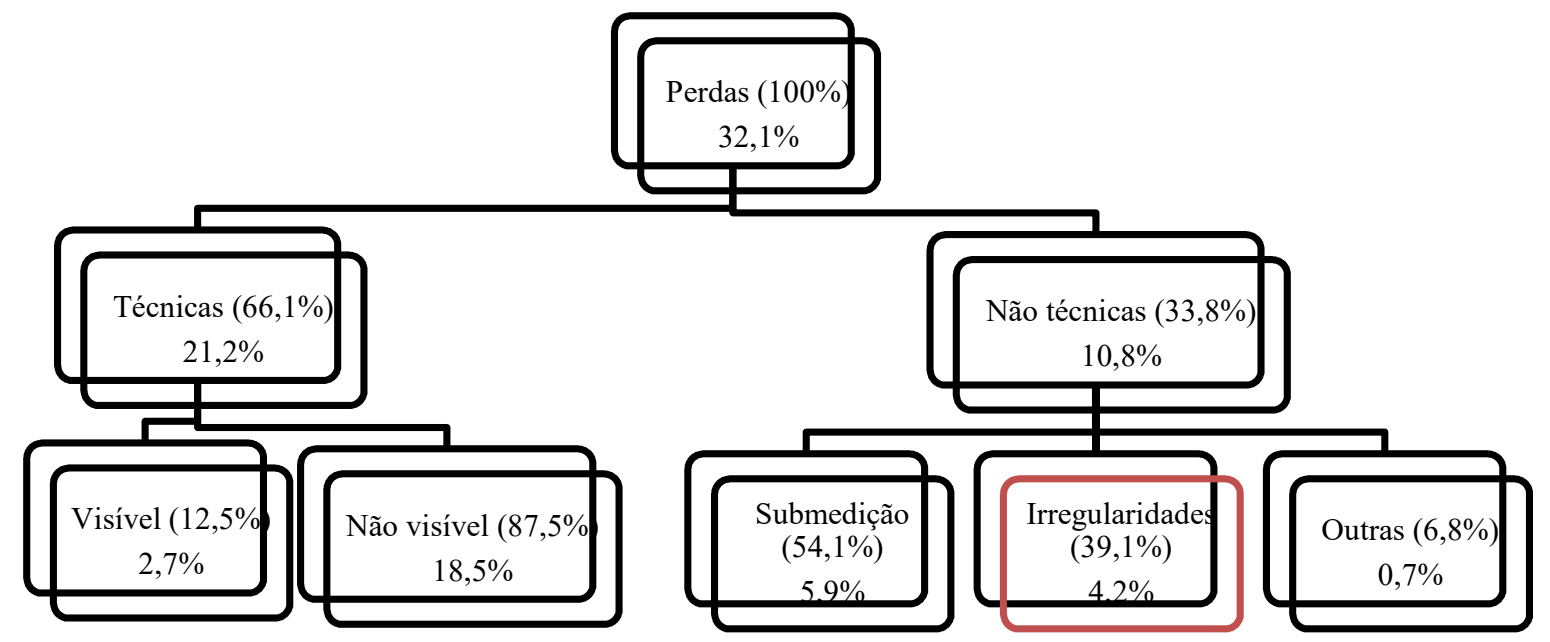

Fonte: Audiência Pública Arsesp - Fevereiro/2013.

A concessionária possui uma área de controle de consumo, a qual utiliza como elemento identificador da ligação o número de Registro Geral Individual (RGI), por meio do qual são controladas todas as informações gerenciais a ela relacionadas.

O controle individual de consumo é, portanto, o principal mecanismo utilizado para apontar uma suspeita de fraude, e quando ela se instala, uma ordem de serviço é emitida para que seja feita uma vistoria no local a fim de constatar se de fato trata-se de fraude. Outras formas de capturar suspeitas de fraude são os canais de denúncia e informações dos empregados que trabalham em campo nos serviços operacionais. Importante ressaltar que a queda do volume micromedido pode decorrer também de outros fatores que não as fraudes.

Além do controle do consumo, as demandas para fiscalizar as suspeitas de fraude são capturadas também por meio de denúncias anônimas ou pela observação dos próprios físcais durante suas atividades regulares de fiscalização de serviços operacionais. 
Quando constatada uma fraude, o infrator pode ser indiciado criminalmente e ficar sujeito à aplicação de penalidade. A fraude é furto qualificado cuja pena varia de 2 a 8 anos de reclusão. No entanto, a aplicação do enforcement legal depende do acionamento da polícia pela concessionária para registrar o boletim de ocorrência, o que pode reduzir a produtividade das equipes em termos de quantidade de suspeitas de fraude vistoriadas, por isso na prática a quantidade de registros de boletins de ocorrência para as fraudes constatadas é pequena.

A ilustração a seguir representa o processo de constatação de uma fraude.

\section{Ilustração 9. Processo de constatação de fraude}

Área responsável pelo controle de consumo observa queda na média de determinado RGI
Área responsável pelo controle de consumo emite ordem de serviço para inspeção in loco por suspeita de fraude

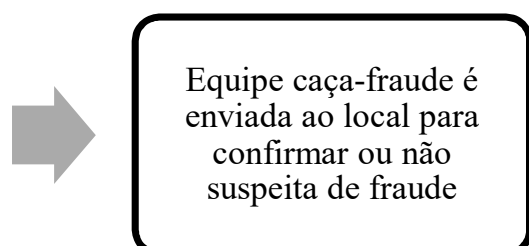

Fraude constatada é registrada no sistema e são aplica dos os procedimentos para cobrança retroativa.
Caso seja constatada a fraude, cabe o acionamento da polícia

Fonte: a autora

Além do impacto financeiro direto gerado pela perda de faturamento e consequentemente de receita, a fraude comercial impacta ainda, de modo indireto, o custo de captação da firma, pois o cliente que frauda não se preocupa em controlar o consumo, que tende a aumentar. O aumento de consumo implica em maior volume de água passando pelas redes de abastecimento, aumentando a probabilidade de perdas físicas, ou seja, aquela perda que é resultante de rachaduras, furos, e outros problemas técnicos que demandam despesas de manutenção. $\mathrm{O}$ aumento das perdas físicas reduz o volume disponível para a população, e consequentemente aumenta a necessidade de captação.

A Diretoria Metropolitana atende um total de 38 municípios, sendo que a maior parte pertence à RMSP. Segundo especialistas, as 70 (setenta) equipes caça-fraudes de que dispõe 
essa diretoria levariam aproximadamente quatro anos para vistoriar todas as ligações da RMSP.

A coordenação das atividades relacionadas ao monitoramento das fraudes dos usuários não apresenta um padrão único, variando conforme a Unidade de Negócio. Algumas centralizam essa atividade na área de controle de consumo, enquanto outras a executam de forma descentralizada, ficando a cargo de cada Atendimento Comercial. No período de 2012 a 2016 o controle sobre as fraudes foi reforçado por meio de dois contratos, cujo escopo era aplicar o enforcement legal ao maior número possível de fraudadores, ou seja, acionar o distrito policial para registrar boletim de ocorrência e dar consequência ao ato ilícito, indiciando e dando voz de prisão conforme o caso.

De acordo com Santos (2011), não existe uma divisão simples entre fraudador e não fraudador. Além disso, é inviável inspecionar todos os consumidores in loco porque a infraestrutura necessária para tal inspeção, além de onerosa, não traria melhorias significativas no resultado final da avaliação de consumo. A questão está na seleção adequada dos domicílios / estabelecimentos comerciais a serem inspecionados. A taxa de identificação de fraudes em inspeções está entre 5\% e 10\% das visitas.

A firma possui mecanismos para detectar uma suspeita de fraude, a partir do que é iniciado um processo para sua confirmação. Segundo os procedimentos internos, toda suspeita de fraude deve ser inspecionada in loco a fim de ser confirmada ou não. Caso seja confirmada, pelo fato de se tratar de ação ilícita, a firma deverá aplicar o enforcement legal registrando boletim de ocorrência e aplicando as sanções cabíveis. Assim, o processo de constatação de uma fraude é custoso, requer expertise e uma estratégia eficaz.

A área comercial possui uma estrutura de governança voltada para detectar as fraudes composta por funções e regras. As regras contemplam: (i) as premissas, que tipificam as condições que permitem caracterizar uma fraude; (ii) o planejamento das ações voltadas para confirmar uma suspeita de fraude e (iii) o planejamento das ações a serem tomadas no caso de ser constatada uma fraude, ou seja, quando uma suspeita de fraude é confirmada.

As regras empresariais definem um padrão de atuação para toda a RMSP e sua elaboração considera as normas da agência reguladora e o Código de Defesa do Usuário. Em termos de operacionalização é permitido certa autonomia às Unidades de Negócio, que podem formular suas próprias estratégias para chegar aos fraudadores. Apresentamos a seguir um detalhamento das regras desenhadas para o controle e detecção das práticas ilícitas dos usuários. 
a) Premissas - as premissas para a constatação de fraudes nas ligações são baseadas no seguinte tripé: (i) na abordagem ao potencial fraudador a visão comercial de longo prazo deverá prevalecer sobre a visão punitiva; (ii) a caracterização de uma fraude deve estar embasada em evidências contundentes e definitivas para afastar a possibilidade de danos acidentais ou decorrentes de serviços correlatos da própria concessionária; (iii) análise da relação do custo da regularização em face do benefício proveniente de eventual cobrança de diferença do consumo no caso dos clientes cadastrados na tarifa favela e social e (iv) aplicação das penalidades contratuais para clientes que possuem tarifa diferenciada, como os contratos de demanda firme e entidades assistenciais.

b) Planejamento das ações dado uma suspeita de fraude - as ações voltadas para a confirmação de situações irregulares devem estar embasadas pelos seguintes elementos e restrições:

- Relatórios de Ocorrências elaborados por inspeções de campo;

- Análise indicando consumo baixo, fora dos parâmetros considerados normais;

- Informações recebidas por meio do registro de denúncias diversas;

- Verificação da existência de irregularidades anteriores no mesmo imóvel;

- Avaliação do potencial de consumo da ligação analisando o custo x benefício da atuação conforme premissas iniciais;

- Priorização de ligações em imóveis de grande capacidade ou volumes e de ligações reincidentes em constatação de irregularidades;

- Quando não for possível identificar um responsável pelo imóvel o prosseguimento da apuração deverá ser analisado por instância superior;

- Os tipos de ocorrências que poderão ser caracterizadas como irregularidades são:

○ Hidrômetro invertido;

○ Hidrômetro manipulado;

○ Hidrômetro travado;

○ Hidrômetro perfurado;

○ Derivação de ligação (by-pass);

○ Ligação clandestina de água ou esgoto;

○ Ligação direta; 
○ Utilização de esgotos por águas oriundas de fontes alternativas sem cadastramento ou abastecimento por caminhão.

- Verificação da necessidade de reparos na ligação;

- Montagem de dossiê;

- Atendimento ao cliente acionado por suspeita de fraude.

c) Planejamento das ações no caso de constatação de fraude - constatada a fraude, avalia-se a sua natureza, extensão e gravidade privilegiando-se o entendimento comercial com o cliente. As seguintes providências são cabíveis, mas não obrigatórias:

- Suspensão do fornecimento de água;

- Aplicação de dispositivo de segurança no hidrômetro, desde que não descaracterize a irregularidade constatada;

- Fotografar a irregularidade arquivando as evidências por cinco anos;

- Notificação formal ao cliente (Comunicado de Irregularidade) e obtenção do "ciente" por parte do mesmo;

- Abertura de Boletim de Ocorrência Policial (BO);

- Execução da supressão da ligação nos casos de clientes com ação judicial ou administrativa contra a concessionária, ou outros casos considerados prioritários pela gerência.

Finalmente, a área comercial faz uma estimativa do consumo não pago para valoração e cobrança retroativa. No processo de valoração para cobrança do consumo não pago, o ponto principal refere-se à alteração do período para retroagir a cobrança, que foi alterado de 60 para apenas 12 meses por determinação da agência reguladora.

Em 2011 a Diretoria Metropolitana implantou um programa de combate a fraudes com o objetivo de padronizar sistemas e recursos para identificar e divulgar agentes fraudadores, indivíduos que 'vendem' o serviço de executar fraudes para os usuários. Nesse programa o contrato de prestação de serviços para averiguação de autoria de fraude tem papel relevante. Com a crise hídrica as averiguações ganharam o apoio direto do governador do Estado de São Paulo e a contratada passou a atuar em conjunto com a Secretaria da Segurança Pública e a contar com divulgação na mídia. 


\subsubsection{Conclusão}

Com relação à percepção dos usuários dos serviços públicos sobre o ato ilícito, pesquisas realizadas no setor elétrico no Brasil evidenciaram que essa prática não é vista como imoral, e em países com níveis de desenvolvimento distintos a moralidade e o grau de cumprimento das regras estão condicionados pela confiança que os clientes depositam no fornecedor do serviço. Nesse sentido, o nível de interação entre a concessionária e o usuário poderia ser representado pela quantidade de atualizações cadastrais efetuadas, ou acatamento de solicitações de serviços e de reclamações dos usuários.

Pela regra da concessionária Sabesp, toda suspeita de fraude tem que ser vistoriada in loco, mas a taxa de constatação de fraude varia de 5 a $10 \%$ do total das vistorias. Sendo assim, 90 a 95\% das vistorias realizadas em ligações com suspeita de fraude não constatam a fraude. Muitas vezes a suspeita não se confirma seja porque não se tratava de fraude, seja porque está muito bem camuflada e os fiscais não conseguem constatá-la. Conclui-se que se as fiscalizações tivessem um foco também educativo os recursos empregados teriam um melhor retorno. 


\section{METODOLOGIA}

Segundo Martins e Theóphilo (2009), a noção de causalidade na área das ciências sociais tem sido evitada devido ao grande número e à complexidade das variáveis que envolvem os fenômenos sociais. Em decorrência disso, são propostos modelos mais flexíveis para a elaboração de hipóteses. Assim, o intuito da pesquisa não é apurar as causas da incidência de fraudes na indústria da água na RMSP, mas investigar o poder explicativo de determinadas variáveis sobre o fenômeno, variáveis essas associadas à perspectiva teórica que embasa o presente estudo.

\subsection{Estratégia de pesquisa}

Segundo Laville (1999), as disciplinas humanas podem interpor barreira à compreensão completa de um problema. O real deveria ser abordado em sua totalidade, como um sistema de fatores relacionados, mas os fenômenos sociais apresentam duas dimensões: uma objetiva e outra subjetiva. Assim, é muito difícil conceber um desenho agregando toda a sua complexidade e multidisciplinaridade.

O fenômeno em estudo são as fraudes no setor de água cometidas pelos clientes da concessionária que presta serviços de abastecimento de água e esgotamento sanitário no Estado de São Paulo, a Cia de Saneamento Básico do Estado de São Paulo, Sabesp. Uma vez que o fraudador é capaz de comportamento voluntário e consciente, o máximo que se pode almejar é definir tendências e observar como os múltiplos fatores que atuam sobre o fenômeno interagem entre si. Abaixo buscamos representar o que, em linhas gerais, buscamos levantar nas dimensões objetiva e subjetiva. 
Ilustração 10. Dimensões da pesquisa
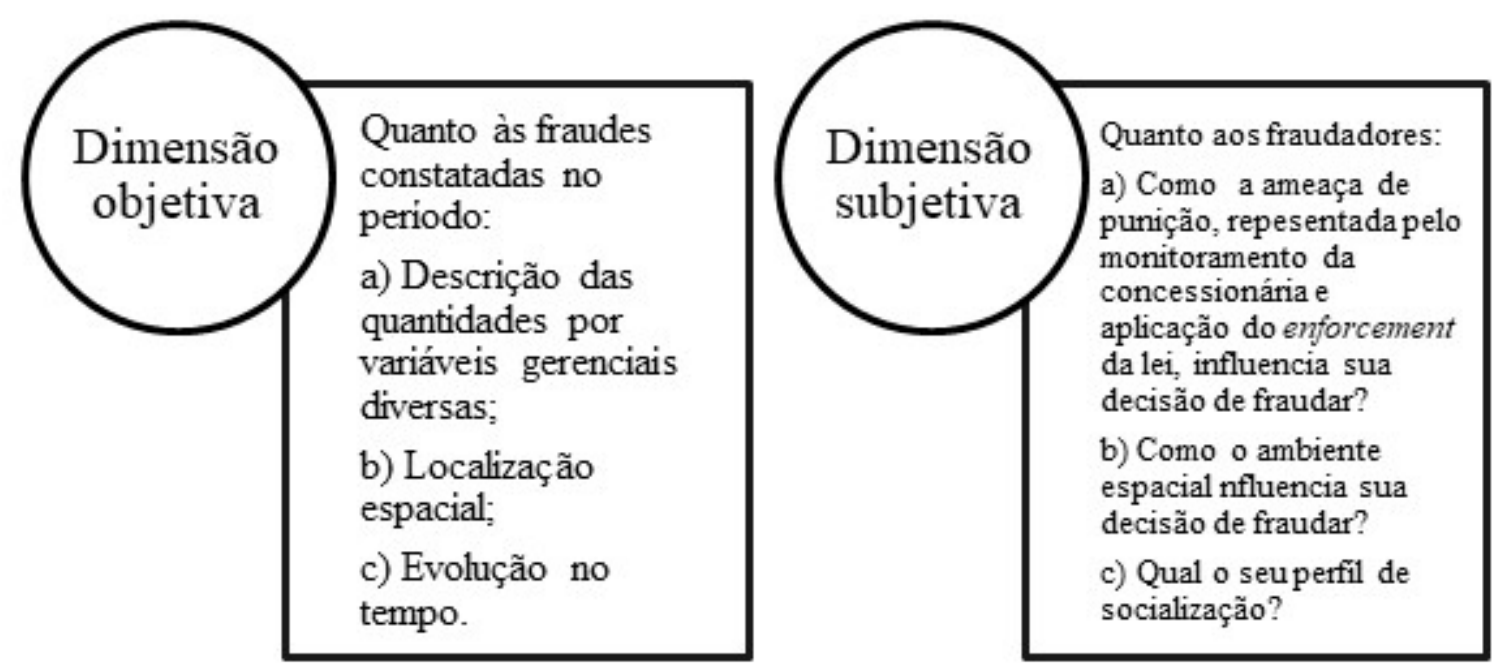

Fonte: a autora

Essa pesquisa utiliza uma abordagem predominantemente quantitativa, mas não única. Por se tratar de um estudo regional, nos valemos também de uma análise espacial, ou seja, uma análise do espaço territorial onde ocorre o fenômeno estudado. Segundo Souza \& Torres (2003), a região pode ser tida como a materialização espacial das diversidades da organização socioeconômica das sociedades: sua matriz produtiva, as trocas, o mercado de trabalho e a urbanidade estão gravados no espaço e expressam a forma como o capital se organiza.

As técnicas utilizadas são a análise descritiva, por referência geográfica, séries temporais e análise inferencial. Quanto aos dados utilizados, parte é de origem gerencial, tendo sido fornecidos pela concessionária, e parte são dados públicos. O campo de pesquisa é a Região Metropolitana de São Paulo e a análise abrange o período de janeiro/2010 a junho/2016.

\subsubsection{Campo da pesquisa}

A Região Metropolitana de São Paulo é a maior do Brasil e uma das maiores e mais complexas regiões metropolitanas do mundo. Em 2016 contava com aproximadamente 21,2 milhões de habitantes, sendo que aproximadamente 11,2 milhões no município de São Paulo. Composta por 39 municípios, a RMSP tem extensão de $8.051 \mathrm{~km}^{2}$ e produz o equivalente a $1 / 5$ da riqueza nacional. 
Conceitualmente as regiões metropolitanas devem compor-se de municípios limítrofes que apresentem relação de integração funcional de natureza econômico-social, além de urbanização contínua, necessitando, portanto, de ação coordenada dos entes públicos que nela atuam. Apresentamos abaixo de forma sucinta o processo de institucionalização da RMSP.

\section{Ilustração 11. Processo de institucionalização da RMSP}

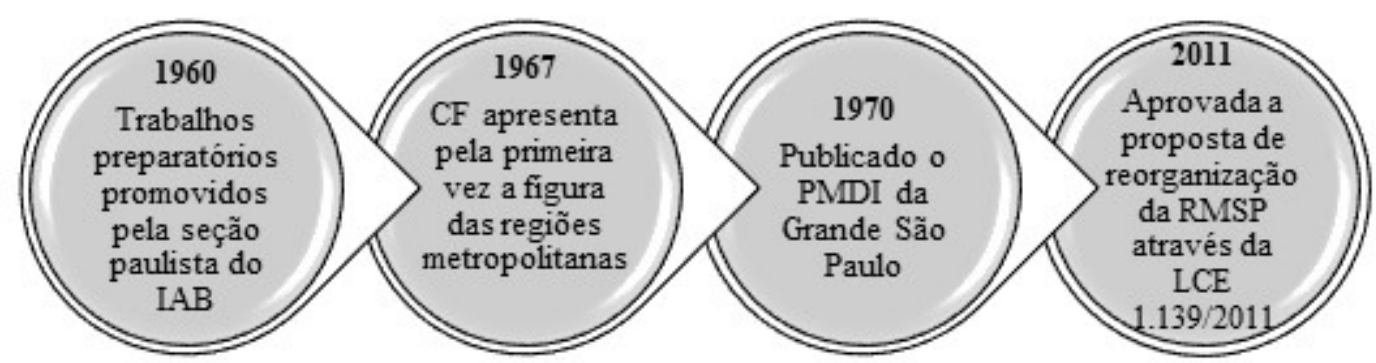

Fonte: IPEA, 2013.

A Lei Complementar Estadual 1.139/2011 aprovou a reorganização da RMSP agrupando trinta e nove municípios em cinco sub-regiões, com o Município de São Paulo integrando todas as sub-regiões, a saber:

- Norte: Caieiras, Cajamar, Francisco Morato, Franco da Rocha e Mairiporã.

- Leste: Arujá, Biritiba-Mirim, Ferraz de Vasconcelos, Guararema, Guarulhos, Itaquaquecetuba, Mogi das Cruzes, Poá, Salesópolis, Santa Isabel e Suzano.

- Sudeste: Diadema, Mauá, Ribeirão Pires, Rio Grande da Serra, Santo André, São Bernardo do Campo e São Caetano do Sul.

- Sudoeste: Cotia, Embu, Embu-Guaçu, Itapecerica da Serra, Juquitiba, São Lourenço da Serra, Taboão da Serra e Vargem Grande Paulista.

- Oeste: Barueri, Carapicuíba, Itapevi, Jandira, Osasco, Pirapora do Bom Jesus e Santana de Parnaíba.

Em termos populacionais, a RMSP situa-se entre os maiores aglomerados humanos do mundo. Entre os nove municípios do Estado de São Paulo com mais de 500 mil habitantes, cinco localizam-se na RMSP, são eles: São Paulo, Guarulhos, São Bernardo do Campo, Santo André e Osasco. Um em cada dez brasileiros reside na RMSP. 
A RMSP é a região metropolitana mais complexa e diversificada do país seja em termos sociais, econômicos e demográficos que, associada à grande extensão territorial, a torna um caso de especial interesse. Por sua vez, São Paulo é a maior cidade da América do Sul e abriga $5,9 \%$ da população brasileira em um território de aproximadamente $1.500 \mathrm{~km}^{2}$. Fundada em 1554, o núcleo original do município de São Paulo contava com cerca de 100 habitantes (IPEA, 2013).

Em 1940 São Paulo contava com mais de um milhão de habitantes e mantinha seu rápido crescimento demográfico. Este padrão de crescimento, predominante até meados dos anos 1970, se expressou em taxas situadas ao redor de 5\% ao ano, consolidando a cidade como o maior centro urbano da América Latina. Nas duas últimas décadas, em decorrência de diversos fatores, entre eles a queda nas taxas de fecundidade e o refluxo do movimento migratório em razão das transformações na estrutura produtiva da cidade, São Paulo reduziu seu ritmo de crescimento populacional, atualmente em torno de $0,8 \%$ ao ano.

Essa pesquisa está circunscrita a 38 municípios operados pela Sabesp, sendo que desses 30 integram a RMSP. Os demais, ainda que localizados nas proximidades da capital paulista, não integram a RMSP, mas são atendidos pela Diretoria Metropolitana da concessionária Sabesp. Assim, dos 39 municípios que compõem a RMSP, os seguintes municípios não fazem parte da análise: Guararema, Guarulhos, Mogi das Cruzes, Santa Isabel, Mauá, Santo André, São Caetano do Sul, São Lourenço da Serra e Juquitiba.

Os oito municípios atendidos pela Diretoria Metropolitana que não integram a RMSP são Bragança Paulista, Piracaia, Nazaré paulista, Pedra Bela, Joanópolis, Vargem, Socorro e Pinhalzinho. Juntos, os 38 municípios analisados somam aproximadamente cinco milhões de ligações de água nas categorias de uso residencial, comercial, mista (residencial e comercial), industrial, assistencial e pública.

\subsubsection{Amostra}

A amostra contempla todas as fraudes cometidas por clientes no período de janeiro de 2010 a junho de 2016 que foram constatadas pela concessionária Sabesp e registradas no seu sistema gerencial. Ou seja, os usuários que fraudaram mantém relação contratual com a concessionária. Consideramos como amostra todas as fraudes constatadas no período indicado, uma vez que a população de fraudes não é conhecida, estima-se que muitas fraudes 
cometidas não são detectadas. A amostra total é constituída por 115,695 fraudes registradas no sistema de controle de fraudes da concessionária.

\subsubsection{Coleta de Dados}

Os dados gerenciais relativos às fraudes coletados para a pesquisa foram fornecidos pela concessionária e obedecem ao princípio do arquivo. Rodrigues (2006) define arquivo como um conjunto de documentos produzidos e recebidos no decurso das ações necessárias para o cumprimento da missão predefinida de uma determinada entidade coletiva, pessoa ou família. Assim, os documentos são acumulados naturalmente no decorrer do tempo à medida que são produzidos. Outra qualidade que se pode ressaltar é a imparcialidade presumida dos documentos acumulados. Essa característica lhe é atribuída porque se presume que os documentos surgem por imposição da natureza das atividades de uma instituição, o que lhes confere verdade administrativa.

O banco de dados contendo as fraudes constatadas é constituído por um arquivo em excel, no qual cada linha corresponde a um número de RGI (Registro Geral Individual), que é o número de identificação do cliente na concessionária Sabesp. Assim, um mesmo número de RGI pode aparecer no banco de dados mais de uma vez, caso mais de uma fraude desse cliente tenha sido constatada no período analisado.

Os atributos relacionados aos RGIs (colunas) que constam no arquivo original fornecido pela concessionária são apresentados a seguir:

- Data da fraude: data em que foi constatada a fraude.

- Atendimento comercial: agrupamento que engloba uma série de RGIs e pode abranger mais de um distrito.

- Unidade de negócio: agrupamento que engloba vários atendimentos comerciais.

- Município: município onde foi constatada a fraude.

- Tipo de ligação: tipo de serviço prestado pela companhia, podendo ser ligação somente de água, ligação de água e esgoto ou ligação somente de esgoto.

- Categoria de uso: finalidade do uso do serviço prestado, podendo ser residencial, comercial, industrial, mista, assistencial ou pública.

- Economia: imóvel ou subdivisão de imóvel, com numeração própria, caracterizada como unidade autônoma de consumo, de qualquer categoria, atendida por ramal próprio ou compartilhado com outras economias. 
- Média: média de consumo em metros cúbicos dos últimos 60 meses retroagidos da data da constatação da fraude.

- Ramo de atividade: tipo de atividade exercida pelo RGI em que foi constatada a fraude, para as categorias de uso comercial e industrial. Para a categoria residencial indica o tipo de habitação, por exemplo: CDHU, favela, residência unifamiliar, condomínio horizontal, etc.

- Tarifa: classificação da tarifa cobrada pelo serviço prestado, podendo ser normal ou popular.

- Endereço.

Posteriormente foi adicionado ao arquivo o atributo relativo ao distrito do município de São Paulo onde está localizado o RGI em que foi constatada a fraude. Um distrito é uma divisão administrativa que abrange um determinado território. O município de São Paulo é dividido em 96 distritos. Esse atributo não consta no arquivo original fornecido pela concessionária porque o controle gerencial não se dá por distrito, mas por atendimento comercial e setores de abastecimento. Para acrescentar o atributo 'distrito' ao qual pertence o RGI (cliente) foi utilizado o número do setor censitário do Instituto Brasileiro de Geografia e Estatística, o IBGE. Setor censitário é um agrupamento utilizado para fins de recenseamento e abrange aproximadamente 300 domicílios. Por meio de sistema de referência geográfica a concessionária associou os RGI's da RMSP aos respectivos setores censitários, que por sua vez estão relacionados a distritos.

Os dados seguintes foram obtidos por meio do sistema de informações gerenciais que controla as fiscalizações da operação, do sistema de informações gerenciais que controla as informações empresariais e de arquivo fornecido pela Superintendência de Auditoria, respectivamente. São eles:

- Quantidade de vistorias (fiscalização) realizadas por mês durante o período analisado, voltadas para confirmar suspeita de fraudes;

- Quantidade de ligações ativas por mês.

- Quantidade de boletins de ocorrência registrados no período.

Os dados a seguir foram obtidos de fontes públicas:

- Coordenadas de latitude e longitude dos endereços das fraudes constatadas (API Google Maps Geocoding 2017); 
- Proporção de pessoas com idade igual ou superior a 10 anos por nível de escolaridade por distrito (INFOCIDADE 2017). Os níveis de escolaridade considerados são:
- Alfabetizado;
○ Fundamental incompleto;
○ Fundamental completo ou ensino médio incompleto;
○ Ensino médio completo ou ensino superior incompleto;
○ Ensino superior completo.

- Proporção de pessoas por nível de IPVS (Índice Paulista de Vulnerabilidade Social) por distrito (Fundação SEADE 2017). Os níveis de IPVS são:

- Baixíssima vulnerabilidade;

- Vulnerabilidade muito baixa;

- Vulnerabilidade baixa;

- Vulnerabilidade média;

- Vulnerabilidade alta (áreas urbanas);

- Vulnerabilidade muito alta (aglomerados urbanos);

- Vulnerabilidade alta (áreas rurais).

O IPVS é um indicador que consiste fatores geográficos, sociais e econômicos a partir de informações oriundas do censo. O índice varia de 1 a 7, ou de 'baixíssima vulnerabilidade', ou seja, aqueles indivíduos que se encontram no topo da pirâmide, a chamada classe A, até 'vulnerabilidade alta', que são os indivíduos que estão na base da pirâmide, praticamente na fronteira da criminalidade.

Esses dados foram utilizados para verificação de possíveis relações com o fenômeno estudado, e adicionalmente foram testados como variáveis explicativas na análise inferencial. Importante ressalvar que os dados educacionais estão disponíveis apenas para o município de São Paulo. 


\subsection{Técnicas utilizadas}

A seguir apresentamos e discutimos as técnicas utilizadas para análise dos dados.

\subsubsection{Análise por referência geográfica}

O corte espacial permite observar inter- relações entre as dimensões econômica, social e dos direitos que são fundamentais para a dinâmica da violência, mas que dificilmente seriam percebidas através da observação da renda apenas. O local de moradia serve tanto para identificar onde as agências da justiça e segurança do estado falham, o que é fundamental para explicar o contexto de baixa mobilidade no qual estão imersas as comunidades pobres, uma vez que o espaço precário pode impedir o acesso aos recursos que possibilitariam a superação das desvantagens com relação aos demais grupos sociais da região estudada.

A partir dos endereços dos usuários que tiveram fraude constatada foram coletadas a latitude e a longitude por meio da API Google Maps Geocoding (2017), e confeccionados os mapas de calor B.1 a B.8, que são apresentados no Apêndice B. Mapa de calor ou heatmap são mapas voltados para identificar áreas com elevada concentração de determinada atividade.

API é uma interface para programação de aplicativos fornecida geralmente quando uma empresa de software deseja disponibilizar dados provenientes de seus serviços para que terceiros desenvolvam aplicações. A API Google Maps Geocoding (2017) aqui utilizada está disponível gratuitamente para a conversão de endereços em coordenadas geográficas ou viceversa. Esta interface requer a utilização de programação em linguagem Python para fazer as solicitações de consulta ao Google Maps via web. Aproximadamente $60 \%$ dos endereços das fraudes foram localizados, o que consideramos um bom resultado, suficiente para a confecção dos mapas.

Essa técnica foi aplicada aos 38 municípios atendidos pela Diretoria Metropolitana da concessionária Sabesp que são objeto desse estudo.

\subsubsection{Análise por séries temporais e análise descritiva}

Um cenário de interesse consiste em visualizar o comportamento da quantidade de fraudes ao longo do tempo, e se possível compará-lo ao comportamento de determinada 
variável ao longo do mesmo período de tempo, para verificar uma possível influência da segunda sobre a primeira. Para isso foi aplicada a técnica das séries temporais.

O objetivo foi visualizar o comportamento da quantidade de fraudes ao longo do tempo por determinadas dimensões. As dimensões utilizadas foram quantidade de fraudes por: (i) Unidade de Negócio; (ii) Unidade de Negócio na categoria residencial; (iii) Unidade de Negócio na categoria comercial; (iv) categoria de uso; (v) tipo de ligação; (vi) faixas de economias e (vii) faixas de consumo médio. Adicionalmente apresentamos também o comportamento da quantidade de vistorias no período a fim de verificar se é possível observar alguma relação entre a quantidade dessa variável e a quantidade de fraudes constatadas.

Uma série temporal é uma sequência de observações de uma variável ao longo do tempo, em ordem sucessiva. Dito de outra forma, uma série temporal é uma sequência de dados numéricos ou quantitativos sobre determinada variável coletados em intervalos regulares durante um período de tempo. De modo geral uma série temporal pode ser genericamente decomposta em termos de tendência, ciclo, sazonalidade e componente aleatório (Armstrong, 2000).

A tendência capta elementos de longo prazo relacionados com a série de tempo, podendo ser determinística, ou seja, uma função matemática, ou estocástica, quando é resultado de um processo aleatório. Alterações que sugerem uma tendência estocástica podem estar associadas a mudanças sociais, tecnológicas, de meio ambiente, das condições de mercado, etc. (Armstrong, 2000).

Os ciclos são caracterizados por longas ondas, mais ou menos regulares, em torno de uma linha de tendência. Eles identificam pontos de mudança ou inflexão e são bastante utilizados na área econômica para determinar períodos de prosperidade, estabilidade e recessão (Armstrong, 2000).

O componente sazonal capta padrões regulares da série de tempo, e são bastante utilizados, por exemplo, no setor agrícola para identificar períodos de seca e períodos de chuva; e no setor de turismo para identificar períodos de alta e baixa temporada, entre outros. Finalmente, o componente aleatório capta todos os efeitos que não foram incorporados pela série de tempo via os outros três componentes, ou seja, é o resíduo (Armstrong, 2000).

Essa técnica foi aplicada aos 38 municípios atendidos pela Diretoria Metropolitana da concessionária que são objeto desse estudo. 
As quantidades de fraudes constatadas foram descritas por município e por distrito para o município de São Paulo por unidade de negócio, atendimento comercial, município e distrito para o município de São Paulo.

A análise descritiva foi aplicada aos 38 municípios atendidos pela Diretoria Metropolitana da concessionária que são objeto desse estudo.

\subsubsection{Análise inferencial (Manski, 1995)}

Por que os cientistas sociais frequentemente proveem perspectivas conflitantes sobre questões de interesse público? O cerne do problema é a inerente dificuldade de estudar o comportamento humano. As conclusões que podem ser extraídas de qualquer análise são determinadas pelas premissas feitas e pelos dados trazidos. A margem de premissas plausíveis sobre o comportamento é ampla. Os dados disponíveis são limitados a observações que podem ser feitas sem intrusões indevidas. Pesquisadores combinam dados limitados com diferentes premissas e frequentemente atingem conclusões logicamente diferentes e válidas.

Um problema de inferência surge quando se tenta interpretar o comportamento de indivíduos que pertencem ao mesmo grupo. Há três hipóteses:

a) Efeito endógeno - quando a propensão do indivíduo para se comportar de determinado modo varia com a prevalência do comportamento no grupo.

b) Efeito correlato - quando indivíduos do mesmo grupo tendem a se comportar similarmente porque eles se defrontam com um ambiente institucional similar ou têm características individuais similares.

c) Efeito contextual - quando a propensão de um indivíduo para se comportar de determinado modo varia com a distribuição das características do grupo.

Os efeitos endógeno e contextual expressam modos distintos de que o indivíduo deve ser influenciado pelo seu ambiente social. O efeito correlato, por sua vez, expressa um fenômeno não social. Alguns termos utilizados para descrever os efeitos endógenos são: conformidade, imitação, contágio, efeito das normas, comportamento de bando, comportamento de rebanho. Distinguir entre efeitos endógenos, contextuais e correlatos é importante porque essas hipóteses têm diferentes implicações para a predição de interações sociais. Por exemplo, se numa escola o desempenho individual melhora com o desempenho médio dos estudantes dessa escola, então um programa efetivo de tutoria não somente ajuda diretamente os estudantes beneficiados, mas, conforme o seu desempenho melhora, 
indiretamente ajuda todos os estudantes da escola, com um feedback para outros ganhos de desempenho pelos estudantes beneficiados com o programa. Efeitos contextuais e correlatos não geram esse multiplicador social.

Comportamento similar dentro de grupos poderiam se originar de efeitos endógenos; por exemplo, membros de grupo poderiam sofrer pressão para se adaptar/conformar às normas do grupo. Ou similaridades do grupo podem refletir em efeitos correlatos; por exemplo, pessoas com características similares podem escolher se associar. Na prática é muito difícil separar esses três efeitos, ou mesmo supor que eles ocorram de forma isolada.

Estudos de inferência estatística buscam caracterizar as geralmente fracas conclusões que podem ser extraídas de um número finito de observações. Essas dificuldades inferenciais podem ser aliviadas somente invocando premissas fortes ou iniciando novo processo amostral que produza tipos de dados diferentes.

\subsubsection{Seleção das Variáveis}

O objetivo da maioria dos estudos empíricos em ciências sociais aplicadas é determinar se uma mudança numa variável causa uma mudança em outra variável e em caso positivo, qual o sentido da associação e em que grau ela ocorre, mantidas todas as demais condições. Para esse propósito geralmente são utilizados dados observacionais. Assim, o objetivo dos estudos quantitativos que utilizam a técnica da regressão é testar hipóteses sobre a expectativa de que o comportamento de certa variável, chamada explicativa ou independente, tem sobre certa variável a ser explicada, chamada variável dependente (Wooldridge, 2002).

Há diversos métodos de seleção de variáveis para obter o melhor modelo de interesse, de acordo com alguns critérios. Dentro desses critérios, há os desejáveis e os necessários, sendo dois deles opostos:

- Buscar o maior número de variáveis possível para fazer boas predições;

- Buscar o menor número de variáveis possível para manter o modelo simples e evitar overfitting.

Seguindo esses critérios, adotamos as técnicas descritas a seguir na escolha de um modelo linear generalizado para explicar a incidência de fraudes no município de São Paulo.

a) Método forward - este método se inicia com um modelo com o menor número possível de variáveis explicativas, contendo apenas uma delas e o intercepto. 
A partir desse modelo, é testada a hipótese de que esta variável tenha o coeficiente igual a zero, contra a hipótese de que seu coeficiente seja diferente de zero. Este procedimento é realizado para todas as variáveis explicativas possíveis, e aquela que apresentar o menor nível descritivo dentre todos os testes, dado que este nível descritivo seja menor ou igual ao nível de significância adotado, é incluída no modelo.

No passo seguinte, é repetido o teste de maneira análoga, considerando o modelo que contém a variável adicionada no passo anterior e adicionando mais uma para nova realização de teste de hipóteses, até que se tenha testado todas as variáveis possíveis (Alencar, Farias \& Figueiredo, 2017, apud Draper, 1998).

b) Método backward - este método se inicia com o modelo completo, contendo todas as variáveis possíveis no modelo. A partir desse modelo completo é testada a hipótese de que todas as variáveis tenham coeficientes maiores que zero, contra a hipótese de que algum coeficiente seja igual a zero.

A variável cujo nível descritivo seja maior que o nível de significância adotado e o maior dentre todas as variáveis explicativas é retirada do modelo e o processo é reiniciado até que se encontrem no modelo apenas as variáveis que sejam significativas, dado o nível de significância adotado.

c) Método stepwise - esse método combina as duas técnicas anteriores continuamente, até o momento em que nenhuma variável seja incluída ou retirada do modelo.

d) Critério AIC - o método AIC, diferentemente dos métodos anteriores, não envolve testes estatísticos. A partir desse critério, é selecionado o modelo que tenha maior verossimilhança e tenha um número reduzido de parâmetros (Alencar, Farias \& Figueiredo, 2017, apud Kutner et al., 2004).

Neste trabalho foram utilizados três métodos: backward, stepwise e AIC. O modelo final foi o escolhido através do método backward combinado com a interpretação dos parâmetros do modelo (Alencar, Farias \& Figueiredo, 2017).

Para modelar a quantidade de fraudes por distrito em São Paulo, foram ajustados modelos lineares generalizados. Modelos lineares generalizados representam uma alternativa aos modelos lineares quando a variável resposta não apresenta uma distribuição normal. Este 
modelo supõe que a variável resposta pertença à família exponencial e que a variância das observações seja constante (Alencar, Farias \& Figueiredo, 2017, apud Paula, 2013).

Para este modelo foi utilizada a distribuição binomial negativa para os dados de contagem da variável "quantidade de fraudes por distrito", distribuição escolhida por se tratar de dados de contagem com superdispersão, fenômeno caracterizado pela variância muito superior à média observada na variável. Como a quantidade modelada foi a ocorrência de fraude, esse valor foi relativizado pela população para cada distrito por meio da função "offset", evitando assim correlações espúrias de maiores populações com mais ocorrências de fraudes (Alencar, Farias \& Figueiredo, 2017).

Os modelos foram ajustados sem interação e com função de ligação logarítmica. Além disso, como foi considerado o offset em todos os modelos, a taxa média mencionada nos modelos se refere à razão entre a quantidade de ocorrência de fraudes e a população dividida por mil (Alencar, Farias \& Figueiredo, 2017). 


\section{RESULTADOS}

Nesse capítulo apresentamos os resultados obtidos por meio das técnicas utilizadas. Com exceção das tabelas referentes aos modelos da análise inferencial, que são apresentadas no decorrer desse capítulo, as demais tabelas, mapas e gráficos referentes à análise descritiva, por referência geográfica e por séries temporais são apresentados nos apêndices.

As tabelas referentes à análise descritiva são apresentadas no Apêndice A.

No apêndice B apresentamos os mapas resultantes da análise por referência geográfica.

No apêndice $\mathrm{C}$ apresentamos os gráficos referentes às séries temporais.

\subsection{Análise descritiva}

As tabelas contendo os resultados apresentados a seguir encontram-se no Apêndice A. Inicialmente foi analisada a distribuição da quantidade de fraudes em relação aos agrupamentos considerados no estudo segundo a área geográfica (atendimento comercial, unidade de negócio, distrito e município), e segundo as características do RGI (tipo de ligação, categoria de uso, economias, média de consumo, ramo de atividade e tarifa).

\subsubsection{Reincidências}

Através da contabilização por RGI (Tabela A.1), verificou-se que a maioria dos fraudadores não foi reincidente no período - mais de $90 \%$ dos fraudadores identificados cometeram apenas uma fraude, aproximadamente 7,6\% dos fraudadores cometeram duas fraudes e $1,5 \%$ chegaram à terceira fraude.

Dos 101.279 RGIs com fraudes constatadas no período, 26 (Tabela A.2) cometeram pelo menos 10 fraudes, todos da categoria residencial, sendo 24 residências do tipo unifamiliar, um condomínio horizontal e um cortiço. Quanto ao tipo de tarifa, 22 são do tipo normal e quatro do tipo popular. Apenas um RGI, localizado em Itaquera, teve registro de boletim de ocorrência.

A quantidade de reincidências ficou aderente à quantidade de fraudes nos respectivos distritos e municípios. Depois de São Paulo, os municípios onde mais reincidências foram constatadas foram Francisco Morato, Itaquaquecetuba e Franco da Rocha (Tabela A.3). 
A unidade de negócio Norte foi a que apresentou a maior quantidade de RGIs com reincidências (Tabela A.4), com $71 \%$ do total. O RGI com maior quantidade observada de reincidências contabilizou 31 fraudes no período analisado e está localizado no município de Francisco Morato. Os atendimentos comerciais Freguesia do Ó, Vila Nova Cachoeirinha, Jaçanã, Arthur Alvim e Itaquaquecetuba também registraram casos de mais de uma irregularidade para o mesmo RGI (Tabela A.5).

\subsubsection{Atendimentos comerciais, unidades de negócio e distritos}

Dentre os 64 atendimentos comerciais que atendem a RMSP, Pirituba obteve destaque contabilizando 5.793 fraudes constatadas, seguida de São Miguel (5.194), Itaim Paulista (4.849), Itaquaquecetuba (4.770) e Santana (4.765). Estas cinco unidades contabilizam juntas 21,9\% das ocorrências (Tabela A.6).

Dos 135 distritos onde foram constatadas fraudes (Tabela A.7), Itaquaquecetuba apresentou a maior quantidade de fraudes residenciais (4.515), seguida por Brasilândia (4.248) e Osasco (3.482). Quando relativizadas pela população do distrito, observamos que Cajamar apresenta uma quantidade de 61,1 fraudes por mil habitantes, muito superior ao segundo e terceiros colocados - distrito de São Miguel, com 25,3 e Socorro, com 23 fraudes por mil habitantes.

As unidades de negócio Leste e Norte somaram mais da metade das fraudes constatadas (Tabela A.8).

\subsubsection{Categoria de uso residencial}

O município de São Paulo tem a maior incidência de fraudes residenciais, totalizando 78.362 no período. Essa quantidade deve-se principalmente ao tamanho da população, com mais de 11 milhões de habitantes segundo o censo 2010 (Tabela A.9), no entanto, quando as fraudes são relativizadas pela população, a proporção de fraudadores em residências é inferior à de outros municípios muito menores, como é o caso de Pirapora do Bom Jesus, com 22,6 fraudes a cada mil habitantes. Francisco Morato também aparece como um dos mais densos em relação à quantidade de fraudes, atingindo 16,8 fraudes para cada mil habitantes.

Os resultados indicaram que $86 \%$ das fraudes foram constatadas na categoria residencial (Tabela A.10). Esse percentual é aderente ao percentual de ligações nessa categoria. Os 
ramos de atividade com maior quantidade de observações - Residencial unifamiliar e condomínios residenciais horizontais (Tabela A.11) - totalizam mais de $84 \%$ dos registros e são subtipos dessa categoria.

\subsubsection{Tipo de tarifa e tipo de ligação}

Quanto à tarifa (Tabela A.12), as fraudes estão distribuídas em dois tipos: normal RC (96\%) e popular e favela (4\%). Como ocorre com relação à proporcionalidade das fraudes com relação à categoria de uso, também no tipo de tarifa os quantitativos são aderentes às respectivas proporções. O mesmo ocorreu no tipo de ligação (Tabela A.13), sendo a maioria de água e esgoto (78\%), e mais de $80 \%$ em locais com apenas uma economia.

\subsubsection{Categoria de uso comercial e industrial}

$\mathrm{Na}$ categoria comercial foram registradas 10.487 fraudes no período analisado, sendo que a unidade de negócio Centro foi a que apresentou a maior quantidade, seguida pela Leste (Tabela A.14).

Em termos de atendimento comercial com atuação no município de São Paulo (Tabela A.15), o que apresentou a maior quantidade de fraudes foi o da Sé, com 1193 ocorrências que equivalem a $11 \%$ do total. $\mathrm{O}$ atendimento dos Jardins ficou na $4^{\mathrm{a}}$ posição com 457 ocorrências.

Os municípios que apresentaram maior quantidade de fraudes na categoria comercial depois de São Paulo foram São Bernardo do Campo e Osasco, e os distritos com maior quantidade de fraudes nessa categoria foram São Miguel, Penha e Santo Amaro (Tabela A.16). Quanto relativizadas pela população, entretanto, os distritos da Sé e do Brás ocupam as primeiras posições, com 8,20 e 5,81 fraudes na categoria comercial para cada 1000 habitantes, enquanto São Bernardo do Campo apresenta apenas 0,57 (Tabela A.17).

Em termos relativos os distritos que apresentaram maior quantidade de fraudes na categoria comercial do que na categoria residencial foram Sé e República. De modo geral, observa-se que isso ocorreu nos distritos mais centrais e de nível sócio econômico elevado (Tabela A.18).

A unidade de negócio que apresentou maior quantidade de registros de fraudes na categoria industrial foi a Leste, seguida pela unidade Centro (Tabela A.19). Na categoria 
industrial, os atendimentos que apresentaram a maior quantidade de ocorrências foram Sé, Penha, São Miguel e Santo Amaro (Tabela A.20).

\subsubsection{Aplicação da lei: registro de BO}

Os dois contratos que apoiaram o combate às fraudes por meio de um acordo com a Secretaria da Segurança Pública atuaram no período de maio/2012 a julho/2013 e outubro/2013 a março/2016. Nesse período foram registrados 440 boletins de ocorrência, indiciados 285 fraudadores, sendo que desses 142 tiveram a prisão decretada.

Os municípios que apresentaram a maior quantidade de registros de boletins de ocorrência foram Osasco (37), Itaquaquecetuba (32) e Barueri (16), e os distritos do município de São Paulo com maior número dessa ocorrência foram República (19) e Pirituba (18), conforme Tabela A.21.

As Unidades de Negócio com maior quantidade de registro de boletins de ocorrência no período foram a Norte, a Oeste e a Centro (Tabela A.22).

Apesar da quantidade de fraudes na categoria de uso residencial ser muito maior do que nas demais categorias, os boletins de ocorrência foram registrados na sua grande maioria (85\%) nas categorias de uso comercial e industrial, que é onde ocorre o desvio dos maiores volumes (Tabela A.23).

Adicionalmente, no Apêndice A apresentamos os gráficos A.1.a A.7, que relacionam a quantidade de fraudes por distrito e a proporção de habitantes nos diversos níveis de vulnerabilidade no município de São Paulo, segundo o IPVS.

$\mathrm{Na}$ análise inferencial a quantidade de $\mathrm{BO}$ não se mostrou significativa para explicar a ocorrência de fraudes.

\subsection{Análise por referência geográfica}

$\mathrm{Da}$ amostra das fraudes constatadas foram recuperadas as coordenadas de aproximadamente $60 \%$ dos endereços. Os endereços não encontrados na base do Google Maps podem não estar catalogados ou ainda apresentarem descrição divergente na base da API.

Nos mapas por município (B1 a B5), foram contabilizadas todas as coordenadas recuperadas através da API, e nos mapas por distrito (B6 a B8), foram contabilizadas apenas 
as coordenadas referentes às fraudes ocorridas entre junho de 2014 e maio de 2015 , por ser o último período cujas coordenadas foram obtidas.

Os mapas indicam que municípios que registraram maior número absoluto de fraudes não correspondem aos que, em relação à sua população, mais fraudam.

A observação dos mapas sugere haver influência geográfica na frequência de ocorrência de fraude, exibindo, dentro do mesmo município, regiões com padrões bem diferentes, como é o caso das regiões oeste e norte no município de São Paulo (B5).

Também é possível visualizar no mapa B4 as fraudes dos municípios de Francisco Morato e Franco da Rocha, que apresentam alta densidade de ocorrências com relação à sua população, como já mencionado anteriormente.

\subsection{Análise das séries temporais}

De uma forma geral foram observados períodos de aumento e diminuição de incidência de fraudes. O ponto mais baixo foi registrado entre o fim do ano de 2013 e início do ano de 2014, e o mais alto no ano de 2016. Não foi possível identificar tendências ou sazonalidades na série geral, conforme se pode observar no Gráfico $\mathrm{C} 1$.

Sobre o possível aumento de fraudes no período da crise hídrica instaurada no biênio 2014/2015 no estado de São Paulo, observa-se ainda no Gráfico 1 uma leve tendência de crescimento após o início de 2014, porém, não é possível afirmar que o aumento foi decorrente do evento em questão.

Pela observação do Gráfico C2, exceto por um ligeiro acréscimo no número de fraudes constatadas acompanhando o acréscimo de vistorias em março de 2010, não é possível identificar influência da quantidade de vistorias (fiscalização) sobre a quantidade de fraudes constatadas.

O comportamento das séries temporais segundo a dimensão das unidades de negócio também não apresenta tendência ou sazonalidade, conforme se observa nos gráficos C3 a C5. Os mesmos picos e declives são observados na maioria das categorias de uso, conforme gráfico C6, não havendo indícios de influência de alguma das variáveis no comportamento da série, que apresenta variações aparentemente aleatórias.

As fraudes segundo o tipo de ligação mostram um comportamento distinto entre as ligações somente de esgoto e as demais, conforme se pode observar no gráfico C7. No entanto, essa diferença é devido ao baixo número de ligações nesta categoria. 
Para as faixas de economias, conforme gráfico C8, não foram observados movimentos que justificassem os aumentos ou vales observados na série geral, o que pode ser constatado também na estratificação por faixa da média de consumo, conforme gráfico C9.

\subsection{Análise inferencial}

Nessa parte apresentamos o resultado de alguns modelos testados.

\section{MODELO 1. Modelo teórico com as variáveis explicativas: Vulnerabilidade Baixa (Vulnerabilidades Baixíssima, Baixa e Muito Baixa agrupadas), Vistorias e Ligações}

$Y_{i}:=$ número de ocorrências de fraude no distrito i, no período de janeiro de 2010 a junho de 2016

$i=1,2,3 \ldots 93$ (índice do distrito)

$Y_{i} \sim$ Binomial Negativa $\left(\mu_{i}, \varphi\right)$,

Em que,

$\mu_{i}:=$ parâmetro da distribuição de $\mathrm{Y}$ - taxa média

$\varphi:=$ parâmetro da distribuição de $\mathrm{Y}$ - forma

$\log \left(\mu_{i}\right)=\beta_{0}+X_{i 1} \beta_{1}+X_{i 2} \beta_{2}+X_{i 3} \beta_{3}$

Sendo,

$\beta_{0}:=$ constante de referência;

$\beta_{1}:=$ variação da média do $\log$ da quantidade de fraudes por distrito quando acrescida uma unidade na variável $X_{i 1}$ (proporção de habitantes com vulnerabilidade baixa no distrito i), mantendo as demais variáveis fixas, $\operatorname{com} X_{i 1}$ variando de 0 a 100. A variável $X_{i 1}$ representa o agrupamento de 3 categorias do IPVS, sendo elas Baixíssima vulnerabilidade, Vulnerabilidade muito baixa e Vulnerabilidade baixa.

$\beta_{2}:=$ variação da média do log da quantidade de fraudes por distrito quando acrescida uma unidade na variável $X_{i 2}$ (quantidade de RGIs fiscalizados dividida pela população no distrito i), mantendo as demais variáveis fixas, com $X_{i 2}$ variando de 0 a 1,5. 
$\beta_{3}:=$ variação da média do log da quantidade de fraudes por distrito quando acrescida uma unidade na variável $X_{i 3}$ (quantidade de RGIs ligados dividida pela população no distrito i), mantendo as demais variáveis fixas, $\operatorname{com} X_{i 3}$ variando de 1,6 a 155,8.

A partir deste modelo, verificamos que as variáveis $\mathrm{X}_{\mathrm{i} 2}$ (RGIs ligados) e $\mathrm{X}_{\mathrm{i} 3}$ (RGIs fiscalizados) não foram significativas ao nível de significância de 5\%. Apresentamos a seguir o resumo do modelo:

Tabela 2 - Resumo do modelo 1

\begin{tabular}{l|r|r|r}
\hline Efeito & Estimativa & Erro Padrão & Valor-p \\
\hline Intercepto & 2,580 & 0,201 & $<0,001$ \\
Vulnerabilidade baixa & $-0,012$ & 0,003 & $<0,001$ \\
Vistorias & $-0,204$ & 0,306 & 0,504 \\
Ligações & 0,004 & 0,004 & 0,272 \\
\hline
\end{tabular}

Como para ambas as variáveis o valor-p foi maior que o nível de significância, elas foram removidas uma a uma do modelo.

Essas duas variáveis não foram incluídas nos modelos finais ajustados por não apresentarem explicação significativa para a variável resposta de interesse. As demais variáveis, descritas na primeira seção deste trabalho, apresentaram comportamento semelhante à quantidade de vistorias e à quantidade de ligações, não apresentando alteração no comportamento da série de fraudes constatadas ao mudar de categoria dentro de cada variável. Dados estes motivos, essas variáveis categóricas não compuseram os modelos.

Removidas as variáveis não significativas do modelo, obtivemos um coeficiente de 0,99 , indicando uma diminuição de $1 \%$ na taxa média de ocorrência de fraudes quando se aumenta em $1 \%$ a proporção de habitantes com vulnerabilidade baixíssima, muito baixa ou baixa.

Além deste modelo considerando o IPVS, ajustamos modelos com as variáveis de escolaridade como o apresentado a seguir: 
MODELO 2. Modelo teórico com a variável explicativa: Sem instrução e ensino fundamental incompleto (escolaridade).

$Y_{i}:=$ número de ocorrências de fraude no distrito i, no período de janeiro de 2010 a junho de 2016

$i=1,2,3 \ldots 93$ (índice do distrito)

$Y_{i} \sim$ Binomial Negativa $\left(\mu_{i}, \varphi\right)$,

Em que,

$\mu_{i}:=$ parâmetro da distribuição de $\mathrm{Y}$ - taxa média

$\varphi:=$ parâmetro da distribuição de $\mathrm{Y}$ - forma

$\log \left(\mu_{i}\right)=\beta_{0}+X_{i 1} \beta_{1}$

Sendo,

$\beta_{0}:=$ constante de referência;

$\beta_{1}:=$ variação da média do log da quantidade de fraudes por distrito quando acrescida uma unidade na variável $X_{i 1}$ (proporção de habitantes sem instrução e ensino fundamental incompleto no distrito i), $\operatorname{com} X_{i 1}$ variando de 0 a 100 .

A partir deste modelo (Modelo C.2), verificamos que o intercepto não foi significativo ao nível de significância de 5\%, e por essa razão foi removido do modelo final. O resumo do modelo pode ser verificado a seguir:

Tabela 3 - Resumo do modelo 2

\begin{tabular}{l|r|r|r}
\hline Efeito & Estimativa & Erro Padrão & Valor-p \\
Intercepto & 0,413 & 0,213 & 0,053 \\
Sem instrução e fundamental incompleto & 0,039 & 0,005 & $<0,001$ \\
\hline
\end{tabular}

Outros modelos foram testados e o modelo final será apresentado na próxima seção. 


\section{MODELO 3. Modelo teórico final}

$Y_{i}:=$ ocorrências de fraude no distrito i, no período de janeiro de 2010 a junho de 2016 $Y_{i} \sim$ Binomial Negativa $\left(\mu_{i}, \varphi\right)$,

Em que,

$i=1,2,3 \ldots 93$ (índice do distrito)

$\mu_{i}:=$ taxa de ocorrência média de fraudes no distrito $\mathrm{i}$

$\varphi:=$ parâmetro de forma da distribuição de $\mathrm{Y}$

$\log \left(\mu_{i}\right)=X_{i} \beta_{1}$

Sendo,

$\beta_{1}:=$ variação da média do $\log$ da quantidade de fraudes por distrito quando acrescida uma unidade na variável $X_{i}$ (proporção de habitantes sem instrução ou com fundamental incompleto no distrito i).

A análise dos resíduos indica que a suposição de homocedasticidade está satisfeita - os resíduos encontram-se, em sua maioria, entre -2 e 2, conforme gráfico 1 .

Gráfico 1. Resíduos X Observações

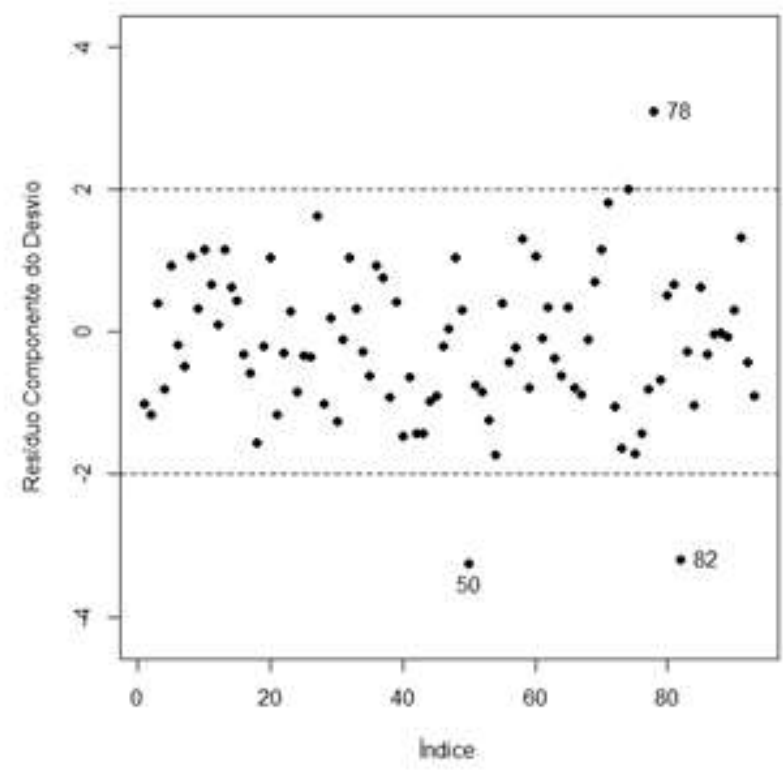

Fonte: Alencar, Farias e Figueiredo (2017). 
O gráfico 2 da distância de Cook, que verifica a presença de pontos influentes, mostra algumas observações mais distantes (74 e 78 - distritos de São Miguel e Sé). A retirada destas observações não melhorou o ajuste do modelo, desta forma, foram mantidas.

\section{Gráfico 2. Distância de Cook X Observações}

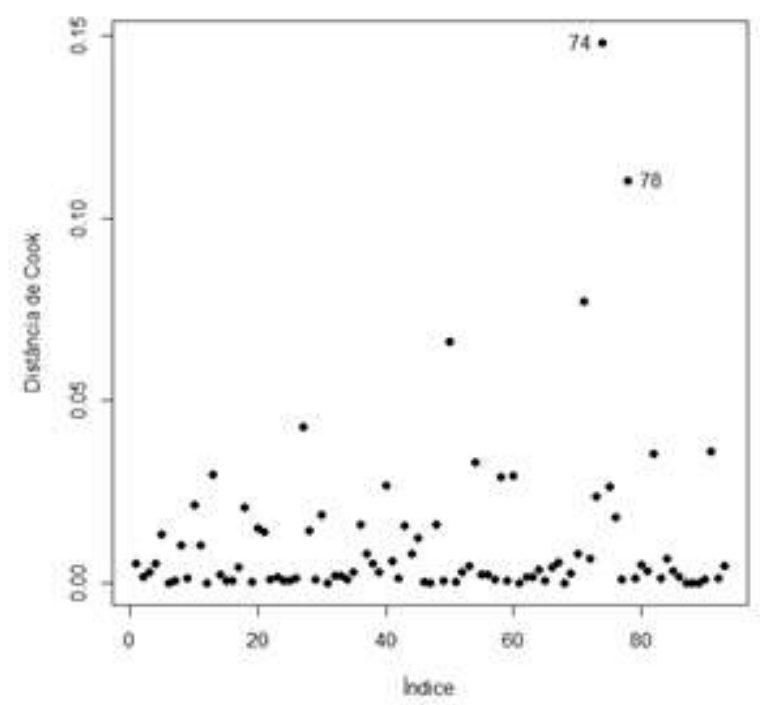

Fonte: Alencar, Farias e Figueiredo (2017).

Observando-se o gráfico 3 da medida h versus valores ajustados, vemos que existe um ponto acima dos demais (50 - distrito de Marsilac), e dois pontos com valores preditos maiores (28 e 40 - distritos de Grajaú e Jardim Ângela), porém não foram identificados como pontos de alavanca.

Gráfico 3. Medida h X Valores Ajustados

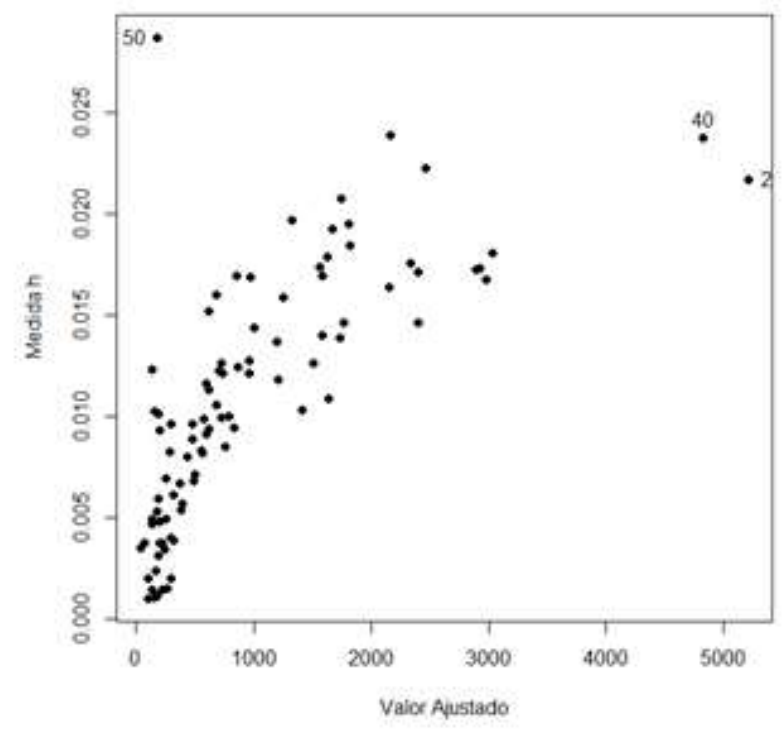

Fonte: Alencar, Farias e Figueiredo (2017). 
Por fim, a maioria dos pontos está dentro da banda de $95 \%$ de confiança (gráfico 4), indicando adequação à distribuição da variável resposta escolhida.

\section{Gráfico 4. Quantil quantil}

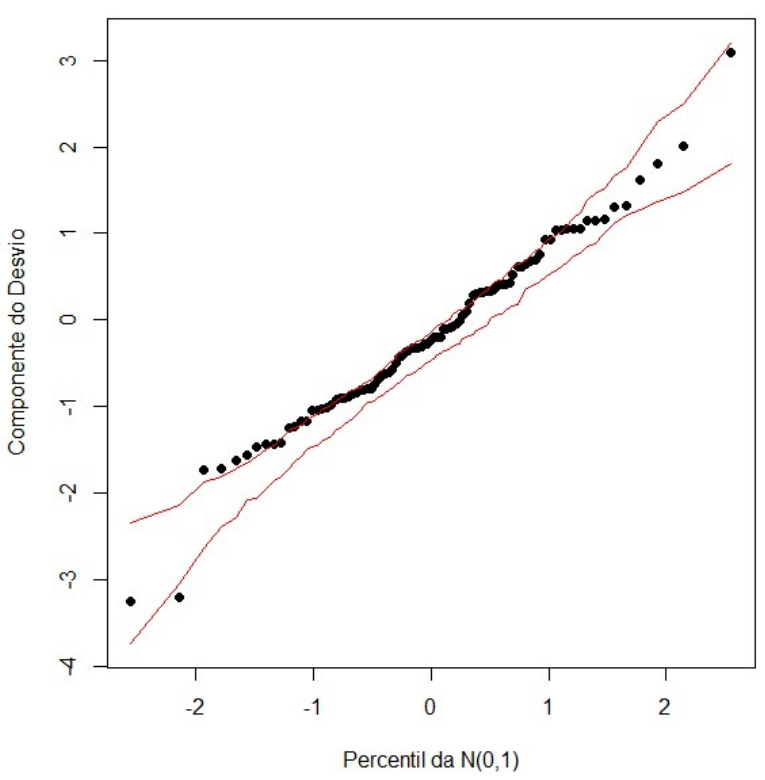

Fonte: Alencar, Farias e Figueiredo (2017).

O modelo final ajustado foi composto por uma única variável sem o intercepto, sendo significativa somente a proporção de habitantes sem instrução ou com escolaridade até o fundamental incompleto, conforme tabela abaixo.

Tabela 4 - Resumo do modelo 3 - modelo teórico final

\begin{tabular}{l|c|c|c|c|c}
\hline Efeito & Estimativa & $\begin{array}{c}\text { Estimativa } \\
\text { Exponenciada }\end{array}$ & $\begin{array}{c}\text { Intervalo de } \\
\text { Confiança }\end{array}$ & Erro Padrão & Valor-p \\
\hline $\begin{array}{l}\text { Sem instrução ao } \\
\text { fundamental incompleto }\end{array}$ & 0,051 & 1,052 & $(1,048 ; 1,056)$ & 0,002 & $<0,001$ \\
\hline
\end{tabular}

A estimativa obtida possui a seguinte interpretação:

$\checkmark$ Tem-se que o aumento de $1 \%$ na proporção de habitantes sem instrução ou com escolaridade até o fundamental incompleto resulta em um aumento de 5,2\% no número de fraudes dentro daquele distrito. 


\section{DISCUSSÃO DOS RESULTADOS}

Nesse capítulo discutimos os resultados relacionados às dimensões objetiva e subjetiva da pesquisa à luz da fundamentação teórica que sustenta o trabalho.

\subsection{Reincidência}

Segundo Carneiro (1996), vulgarmente reincidência significa voltar a incidir, recair, ou repetir determinado ato. Juridicamente reincidência é a situação daquele que volta a delinquir após ter sofrido condenação anterior. Para Carvalho e Peixoto (1972) reincidência significa pertinácia, teimosia, o que é corroborado por Azevedo (1974), que aloca o termo na categoria de ato de vontade individual relacionado à ideia de obstinação.

No presente estudo, entre diversas explicações possíveis, reincidir pode sinalizar que as medidas tomadas para combater o ato ilícito não são suficientes para inibir o fraudador, quer porque ele não tem condições de cumprir com suas obrigações contratuais, e nesse caso é insensível ao risco; quer porque ele tem a percepção de que a probabilidade de ser pego é baixa; ou ainda porque tem a percepção de que se for pego a probabilidade de ser punido criminalmente é baixa e a sanção financeira será menor do que o benefício auferido com o consumo ilícito.

Verificando detalhadamente os 26 RGIs com 10 ou mais fraudes registradas (Tabela A.1), observamos que nos distritos de Francisco Morato, Brasilandia, Itaquera, São Domingos, Limão e Jardim Ângela, para o mesmo RGI há mais de uma fraude registrada no mesmo dia, sendo que no Jardim Ângela observou-se 11 registros de fraude no mesmo dia e outras duas no dia subsequente para o mesmo RGI, o que não faz sentido. Observamos ainda diversos casos de registro de fraude no mesmo mês. As razões que levaram a essas inconsistências não são relevantes para esse estudo, mas o que é importante ressaltar é que elas evidenciam uma condição assumida em estudos empíricos, segundo a qual os valores de medição e observação são apenas parcialmente conhecidos, o que não invalida o estudo. Outro ponto é que a quantidade dessas ocorrências é irrelevante.

Dessa forma, concluímos que uma amostra que apresenta mais de 90\% dos RGIs sem reincidência; mais de $9 \%$ com uma ou duas reincidências e menos de $1 \%$ com três ou mais reincidências é válida e representa adequadamente o fenômeno estudado. 


\subsection{Perfil dos fraudadores}

$\mathrm{Na}$ categoria residencial observou-se que nos distritos e municípios com maior incidência de fraudes há diversos logradouros, que podem ser ruas, avenidas, praças, etc., que apresentaram mais de 40 ocorrências desse tipo. A rua com maior quantidade em toda a amostra fica no distrito paulistano de Brasilândia, totalizando 144 fraudes, sugerindo que os fraudadores nessa categoria tendem a adotar um comportamento aderente ao ambiente em que estão inseridos (embeddedness), ou ao grupo ao qual pertencem.

Se contabilizadas por unidade de negócio, as fraudes na categoria residencial apresentam três claras subdivisões: Unidades Leste e Norte com aproximadamente $30 \%$ das fraudes cada; Unidades Sul e Oeste com aproximadamente 16\% cada; e unidade Centro com aproximadamente $9 \%$ das fraudes constatadas. Adicionalmente, nas áreas abrangidas pelas unidades Leste e Norte, os municípios e distritos mais populosos e com menor nível de infraestrutura compatível com a população local, cujo nível sócio econômico é comparativamente o mais baixo no âmbito da população analisada, são os que apresentaram os maiores índices de fraudes no período analisado.

Nas tarifas popular e favela é necessário avaliar o custo de regularizar a fraude versus o benefício proveniente da cobrança retroativa do consumo ilícito. 4\% do total das fraudes constatadas no período são de clientes cadastrados nessas tarifas. Esse percentual é proporcional à quantidade de RGIs cadastrados nesses tipos de tarifa, o que indica que, ainda que o benefício auferido não compense o custo da regularização da fraude, as fiscalizações mantém uma proporcionalidade, de onde se depreende que o aspecto financeiro não é o que prevalece quando se trata de detectar e punir a fraude.

Ao contrário do observado na categoria residencial, na categoria comercial a unidade de negócio que apresentou a maior quantidade de fraudes foi a Centro, que atende a população com o nível sócio econômico mais elevado da RMSP. Em termos percentuais, nessa categoria os distritos com nível sócio econômico médio, alto e muito alto apresentaram mais fraudes na categoria comercial do que na categoria residencial.

$\mathrm{Na}$ categoria industrial a unidade de negócio Centro também se destacou, ficando atrás apenas da unidade de negócio Leste, que atende a área mais populosa do município de São Paulo.

As categorias comercial e industrial guardam semelhanças entre si. O atendimento comercial Sé apresentou a maior quantidade de fraudes em ambas as categorias. Entre os 10 
atendimentos que mais fraudam em ambas as categorias, as diferenças ficam por conta do atendimento dos Jardins, que figura na quarta posição na categoria comercial, mas não figura entre os 10 primeiros na categoria industrial, e Itaim Paulista, que ocupa a sétima posição na categoria industrial, mas não figura entre os 10 primeiros na categoria comercial. Os atendimentos de Santo Amaro, São Miguel, Penha, Santana, Mooca e Campo Limpo figuram em ambas as categorias entre os 10 que mais fraudam.

Os mapas auxiliam bastante na identificação de padrões de ocorrência de fraude por área geográfica, evidenciando a influência do ambiente social, e confirmam os resultados da análise descritiva, ou seja, em regiões mais pobres e mais populosas há maior incidência de fraudes na categoria residencial do que em regiões mais centrais, com infraestrutura mais consolidada e indivíduos com nível sócio econômico mais elevado.

\subsection{Aspectos sócio econômicos}

Os resultados da análise inferencial confirmam os resultados obtidos por meio da análise descritiva e geográfica. O modelo 1 aponta que o fraudador 'típico' na categoria residencial vive em área com vulnerabilidade média, alta ou muito alta. O modelo 2 reforça esse resultado, indicando que a variável 'sem instrução e ensino fundamental incompleto' é significativa para explicar a maior incidência de fraudes nos distritos que apresentam maior índice de indivíduos nessa condição.

O nível de instrução foi a variável que se mostrou significativa para modelar a incidência de fraudes na RMSP. Entretanto, o elevado número de fraudes (85\%) observado na categoria residencial influencia esse resultado. Além disso, como anteriormente comentado, na categoria comercial a maior incidência de fraudes não ocorre nos distritos com esse perfil, mas em distritos com nível sócio econômico mais elevado. Assim, é lícito concluir que essa variável é significativa para explicar a incidência de fraudes na categoria residencial, mas não explica a ocorrência de fraudes nas categorias comercial e industrial.

A análise custo x benefício de Becker (1974) encontra respaldo nas fraudes observadas na categoria comercial. Essa racional está relacionada a um comportamento individual embasado no auto interesse, que por sua vez é associado à vertente sociológica undersocialized.

Embora os volumes consumidos de forma ilícita não tenham entrado na análise, é sabido que as fraudes na categoria residencial são mais numerosas, mesmo porque a 
proporção de ligações nessa categoria é muito maior, mas são as fraudes verificadas nas categorias comercial e industrial as responsáveis por subtrair os maiores volumes de água, e consequentemente provocam maior prejuízo financeiro à empresa e maiores malefícios à sociedade.

\subsection{Mecanismos de monitoramento}

Os mecanismos de monitoramento, tanto internos à firma, como a fiscalização, quanto externos, como o enforcement legal, em última análise representam custos de transação para proteger direitos de propriedade (Demsetz, 1964; Buchanan, 1971; North, 1990). Uma norma pode ser vista como um bem comum e o seu cumprimento promove a ordem social, e assim sendo, o seu descumprimento está sujeito a punição. A ideia é que a ameaça de punição detenha o crime.

Entretanto, a aplicação da lei envolve custos, e uma vez não aplicada, a norma legal perde sua eficácia e sua força. Desse modo, a ordem social pode ser 'quebrada' e a incerteza aumenta porque a não efetividade da norma pode gerar malefícios.

A análise por séries temporais ficou aderente à análise inferencial, pois ambas sinalizam que a fiscalização da concessionária não exerce influência importante sobre o comportamento de fraude. Assim, não é possível rejeitar a hipótese nula, de que os mecanismos internos de monitoramento da concessionária não tem efeito significativo sobre a quantidade de fraudes constatadas nos distritos do município de São Paulo e municípios da RMSP.

Em números absolutos a unidade de negócio Norte foi a que registrou maior quantidade de boletins de ocorrência para fraudes confirmadas, o que faz sentido, uma vez que nessa unidade, ao lado da unidade Leste, observou-se a maior quantidade de fraudes. Entretanto, em termos percentuais a unidade Centro registrou mais boletins de ocorrência do que a Norte, muito provavelmente por ser a unidade em que ocorrem mais fraudes na categoria comercial, onde os volumes subtraídos são maiores.

Ressalta-se que a área atendida pela unidade Centro possui a melhor infraestrutura em termos de serviços públicos de saúde, educação, transporte e segurança. Assim, pode ser menos custoso para a concessionária aplicar a lei nessa região, e por isso mesmo o fraudador precisa ser mais ousado, de onde se pode concluir que o benefício auferido compensa o risco.

Não foi possível modelar a aplicação do enforcement legal pela concessionária devido à pequena quantidade de boletins de ocorrência registrados no período face à quantidade de 
fraudes constatadas. Uma possível explicação para isso seria o modo como foi testado, considerando todas as fraudes em todas as categorias. Uma vez que se conhece que os BOs foram concentrados nas fraudes da categoria comercial, é possível que uma análise do seu efeito somente sobre essa categoria produza resultados diferentes.

\subsection{Ação social}

Um ponto de interesse desse trabalho se constitui em investigar se a decisão do indivíduo de fraudar é mais influenciada pelo ambiente, pressão da comunidade e normas de etiqueta do grupo, ou pela atuação da empresa, por meio da aplicação dos mecanismos de monitoramento interno e externo. Em ambos os casos, entretanto, a norma importa.

Apesar do link entre o ambiente, representado pela comunidade, e a decisão de fraudar não ter sido operacionalizado na análise inferencial, as análises descritiva e geográfica permitem afirmar que essa relação existe.

No caso da categoria comercial, ficou demonstrado que a busca do auto interesse incorpora atos ilícitos. Uma explicação possível é que os mecanismos institucionais internos e externos não são suficientes para inibir a fraude. Desse modo a competição é desleal e o ambiente econômico se torna instável tanto para competidores quanto para consumidores.

$\mathrm{Na}$ categoria comercial o ato ilícito confronta o direito socialmente definido, na forma da lei. Assim para o fraudador dessa categoria a norma não importa, seja porque em sua percepção vale à pena correr o risco de infringi-la, seja porque ele possui meios de livrar-se da sanção. Essa constatação corrobora Coleman (1986; 1990), que afirma que pessoas influentes não somente têm menor probabilidade de sofrer sanções, como também menor probabilidade de obedecer às normas do que as pessoas menos influentes.

Um ponto sensível é a alteração da regra pela agência reguladora, que reduziu de 60 para 12 meses o prazo para retroagir a cobrança dos volumes consumidos e não faturados. $\mathrm{Na}$ prática, essa alteração contribuiu para aumentar a utilidade do ato ilícito. 


\section{CONSIDERAÇÕES FINAIS}

Para a firma as fraudes se configuram como um tipo de perda comercial e impactam negativamente sua receita reduzindo o fluxo de benefícios futuros provenientes da melhor utilização dos ativos. Adicionalmente, as fraudes induzem ao desperdício de água, que provoca o aumento das perdas físicas, impactando indiretamente sobre o custo de captação do recurso.

A firma possui mecanismos de monitoramento ex post, e em se tratando de ato que vai de encontro ao ordenamento legal, as instituições de enforcement da lei deveriam ser acionadas. Os indivíduos, entretanto, a depender da sua condição sócio econômica, ambiente social e de sua condição espacial, que representa o lugar onde reside, podem reagir de modo distinto em face das restrições impostas pela lei e dos custos e benefícios provenientes do seu cumprimento.

O comportamento criminoso subverte a ordem legal e econômica e prejudica o desenvolvimento de uma sociedade. As fraudes na indústria da água geram efeitos negativos para a firma e para a sociedade. Assim, investigar como a ameaça de punição pode deter esse tipo de crime é relevante para melhorar a eficácia e assertividade do monitoramento ex post. Nesse sentido, a proposta desse estudo foi investigar como as instituições internas da firma, voltadas para monitorar o contrato, e externas, voltadas para proteger os direitos de propriedade, influenciam o comportamento de fraude na Região Metropolitana de São Paulo.

Pelos resultados obtidos, a ameaça de punição, representada pela fiscalização da concessionária e detecção da fraude, não tem efeito importante sobre a decisão de fraudar no caso da fraude cometida na categoria residencial. Os resultados indicam que as fraudes nessa categoria de uso estão relacionadas ao baixo nível de instrução formal do fraudador e à influência da comunidade ou do grupo. Desse modo, é lícito concluir que os indivíduos fraudadores, nesse caso, são influenciados pelo embeddedness (Granovetter, 1985) e apresentam um comportamento mais aderente à vertente oversocialized ou institucionalista da ação social (Coleman, 1990). Um achado que corrobora essa tendência é o fato de que 90\% dos RGIs com fraudes constatadas no período não apresentaram reincidência.

Assim sendo, uma vez que a fiscalização não se mostrou relevante na decisão de fraudar ou não fraudar para as fraudes da categoria residencial, e o fraudador nessa categoria possui baixo nível de instrução formal, consideramos que a fiscalização poderia ser mais efetiva se tivesse um caráter mais educacional do que punitivo para esses usuários, buscando 
internalizar nas comunidades o valor da água e da cidadania, uma vez que esse fraudador se comporta de forma mais socializada. Assim, a firma deveria mirar a mudança institucional no sentido de mudar o comportamento da comunidade.

Adicionalmente, pode-se concluir que tipicamente o fraudador na categoria residencial se encontra na 'fronteira' da criminalidade. Esse cliente não é passível de enquadramento na tarifa social. Todavia, ele apresenta uma condição social vulnerável e sendo assim precisa de ‘incentivo' para optar por não fraudar. Desse modo, consideramos que uma saída possível seria aproveitar o efeito oversocialized, que nessa categoria aparentemente predomina sobre o comportamento undersocialized, para instituir a solução coseana com base na troca multinalteral, na qual cada indivíduo teria que, por assim dizer, 'renunciar' ao direito de fraudar, em troca da renúncia dos demais indivíduos em prol de um benefício para a sua comunidade.

Com base na proposta de Coase seria estipulada uma espécie de 'tarifa-cidadã', intermediária entre a tarifa normal e a tarifa popular, cuja aplicação, ao invés da análise individual, teria como base a região espacial, com foco em comunidades, nas quais todo o grupo seria responsável por sua obtenção e manutenção, obedecendo ao princípio da troca multilateral. A tarifa-cidadã criaria uma espécie de status para as comunidades que a conquistassem, aumentando sua auto estima, com aspectos positivos tanto em termos financeiros para a firma, quanto em termos de externalidades positivas para a sociedade (Coleman, 1986; 1990).

Nas categorias de uso comercial e industrial os resultados indicam que as fraudes ocorrem predominantemente em regiões com nível sócio econômico médio, alto e muito alto. Nesse caso é lícito concluir que a motivação do fraudador é aderente ao argumento de Becker (1974), quando afirma que um ato ilícito é resultado de uma análise que confronta o benefício vislumbrado com o potencial custo associado, e dessa forma incorpora o comportamento racional ilegal e outras ações anti sociais, nas quais a decisão é influenciada pela probabilidade de ser pego e, em sendo pego, à probabilidade de ser punido.

Aplicar a lei tem custo. Entretanto, no caso das fraudes nas categorias comercial e industrial, o ideal é que ela fosse $100 \%$ aplicada, e se não for possível, então para o maior número possível dos casos de fraude confirmada, dando o máximo de publicidade ao ilícito, de modo a incorporar à punição pelo descumprimento da norma legal também o efeito do descumprimento da norma social, na forma de perda de confiança geral no produto e no preço praticado pelo malfeitor. Como não temos um mercado idealizado, no mundo real compete à 
sociedade e às empresas tornar as estruturas políticas repressivas efetivas em aderência ao auto interesse civilizado (Hirschmann 1977).

Como não foi possível incluir no modelo a aplicação da lei e seu efeito sobre as fraudes, novas pesquisas nessa linha teórica deveriam se voltar para investigar o efeito desse mecanismo segregando por categoria de uso.

Finalizando, a partir do fenômeno das fraudes comerciais na indústria da água, analisada à luz de premissas extraídas da economia institucional, esse trabalho coloca foco numa questão relevante em países emergentes, que é a da condição sócio econômica do indivíduo prevalecer, até certo ponto, sobre fatores de ordem moral, relacionados à perspectiva de serem pegos e punidos. Entendemos que na indústria da água, que necessita de mecanismos que induzam à ação coletiva para reduzir seus custos de transação, e assim melhorar sua eficiência econômica, essa questão é fundamental. Nesse sentido, consideramos que esse trabalho cumpre seu intento e contribui para retomar os limites do conhecimento.

Os achados desse estudo caracterizam associação empírica entre crimes reportados numa determinada região e premissas oriundas da economia institucional. Entendemos que, fora dos limites da RMSP, mesmo considerando outras regiões metropolitanas do Brasil, esses resultados teriam que ser validados por meio de uma nova pesquisa, uma vez que os mecanismos de monitoramento das concessionárias podem apresentar diferenças. Isso vale também para a aplicação a outros países, pois nesses casos pode haver diferenças importantes no sistema de normas formais e informais. 


\section{REFERÊNCIAS}

Acemoglu, D.; Johnson, S.; Robinson, J. A. (2005) Handbook of Economic Growth, Vol. 1.A. Edited by Philippe Aghion and Steven N. Durlauf Elsevier B.V.

Adger, W. N. (2003) Social capital, collective action, and adaptation to climate change. Economic Geography, Vol. 79, No. 4.

Akerlof, G. A.; Kranton, R., E. (2000) Economics and identity, The Quarterly Journal of Economics.

Alchian, A. (1965) Some economics of property rights, Il Politico, Pavia, Italia, v.30, p.816829.

Alchian, A. (1988) The firm is dead; long live the firm a review of Oliver Williamson's The Economic Institutions of Capitalism, Journal of Economic Literature.

Alencar, A. P., Farias, E. A., Figueiredo, M. K. (2017). Relatório de Análise Estatística sobre o Projeto: "Instituições, Controle Gerencial e a Governança das Fraudes dos Clientes dos Serviços de Água no município de São Paulo", (RAE CEA 17P18).

Anderson, S.; Baland, J. M.; Moene, K.O. (2009) Enforcement in informal saving groups, Bread Working Paper No. 74, Journal of Development Economics.

Andrade, L. F. N. \& Sahad, S. (2007) Considerações sobre o fundamento moral da propriedade. KRITERION, Belo Horizonte, N. 11.

Angelos, E. W.; Cortes, O. A. C.; Saavedra, O. R.; Souza, A. N. (2011), Detection and identification of abnormalities in comsuptions in power distribution systems, IEEE Transactions on Power Delivery, Vol. 26 No. 4, octover 2011.

API Google Maps Geocoding (2017). Disponível em <https://developers.google.com/ Maps/documentation/javascript/geocoding?hl=pt-br $>$, acessado em 20 de agosto de 2017.

Araújo, A.C.M. (2007), Perdas e inadimplência na atividade de distribuição de energia elétrica no Brasil, Tese submetida ao PPGE da UFRJ. Rio de Janeiro.

Argyres, N. S.; Liebeskind, J. P. (1989) Contractual commitments, bargaining power and governance inseparability: incorporating history into transaction costs theory, The Academy of Management Review. 
Armstrong, J. S. (2000) The forecasting dictionary. In: Principles of forecasting: a handbook for researchers and practitioners, Norwell (MA), United States of America: Kleewer Acad. Publishers, 2000.

Axelrod, R. (1986) An evolutionary approach to norms, The American Political Science Review, Vol. 80, No. 4, pp.1095-1111.

Azevedo, Francisco F. S. (1974), Dicionário Analógico da Língua Portuguesa (Ideias Afins), Coordenada Editora de Brasília.

Bajari, P.; Tadelis, S. (2001), Incentive versus transaction costs: a theory of procurement contracts, Journal of Economics.

Barzel, Y. (1989) Economic analysis of property rights. Cambridge University Press.

Becker, G. (1974) Crime and punishment: an economic approach. In: Essays in the economics of crime and punishment. Volume author/editor: Gary S. Becker and William M. Landes.

Becker, G. S.; Stigler, G. J. (1974) Law enforcement, malfeasance, and compensation of enforcers, The Journal of Legal Studies.

Buchanan, J. M. (1971) The Limits of Liberty: Between Anarchy and Leviathan Chicago: University of Chicago Press, Caps. 2-4, pp. 17-73.

Buonanno, P.; Durante, R.; Pratolo, G. (2012) Poor Institutions, Rich Mines: Resource Curse in the Origins of the Sicilian Mafia, Working Paper No. 261, http://www.carloalberto.org/assets/working-papers/no.261.pdf.

Carneiro, José C. S. (1996), Estudo sobre a reincidência, Justitia São Paulo, 58 (174).

Carvalho, J.; Peixoto, V. (1972), Dicionário da Língua Portuguesa, Cultural Brasil Editora Ltda.

Coase, R. (1937) The nature of the firm, Economica.

Coase, R. (1960) The problem of social cost. Journal of Law and Economics.

Coase, R. (1991), Prize Lecture, Lecture to the memory of Alfred Nobel, December 9.

Cohen, M. R. (1927) Property and Sovereignty, 13 Cornell L. Rev. 8. 
Coleman, J. S. (1986) Social Theory, Social Research, and a Theory of Action - The American Journal of Sociology, Vol. 91, No. 6, pp. 1309-1335.

Coleman, J. S. (1990) Foundations of Social Theory, Cambridge: The Belknap Press of Harvard University Press, caps. 2-4, e 6, pp 27-90 e 119-144.

Commons, J. R. (1931) Institutional Economics, American Economic Review vol. 21 pp. 648657.

Demsetz, H. (1964) H. The exchange and enforcement of property rights, Journal of Law and Economics, Vol. 7 pp.11-26.

Depuru, S.S.S.R.; Wang, L.; Devabhaktuni, V. (2011), Electricity theft: overview, issues, prevention and a smart meter based approach to control theft, Energy Policy.

Dixit, A. (2009) Governance Institutions and Economic Activity .American Economic Review.

Draper, N. R.; Smith, H. (1998), Applied Regression Analysis, 3a Ed. New York: Wiley. $706 \mathrm{p}$.

Eggertsson, T. (1990) Economic Behavior and Institutions, Cambridge Surveys of Economic Literature, Cambridge: Cambridge University Press.

Ehrlich, I. (1973) Participation in Illegitimate Activities: a theoretical and empirical investigation, The Journal of Political Economy, Volume 81, Issue 3, 521-565.

Francisco, E. R.; Fagundes, E. B.; Ponchio, M. C.; Zambaldi, F. (2010), Development of an indicator of propensity to energy commercial losses using geospatial statistical techniques and sócio-economic data: the case of AES Eletropaulo. RAM, Rev. Adm. Mackenzie, V. 11, No. 4., São Paulo, SP.

Ghajar, R. F.; Khalife, J. (2003), Cost/benefit analysis of an AMR system to reduce electricity theft and maximize revenues for Électricité du Liban, Applied Energy 76, 35-37.

Gorringe, P. (1987), The economic institutions of capitalism: firms, markets and relational contracting by Oliver E. Williamson, Australian Journal of Management.

Granger, T. (1997), Le renouveau de la théorie des organisations Lecture critique de trois ouvrages recentes: Economics, Organization and Management de Paul Migrom et John Roberts (1992) La théorie modern de 1'entreprise d'Hubert Gabrié et Jean-Louis Jacquier (1994) L'économie des organisations de Claude Mènard (1990), Revue économique, Vol. 18 No. 1 
Granovetter, M. (1985) Economic action and social structure: the problem of embeddedness. American Journal of Sociology, 91, 481-510.

Granovetter, M. (1992) Economic institutions as social constructions: a framework for analysis, Acta Sociologica, 35: 3-11.

Granovetter, M. (2005) The impact of social structure on economic outcomes, Journal of Economic Perspectives, Vol $19 \mathrm{~N}^{\mathrm{o}} 1$.

Gray, W. B.; Deily, M. E. (1996), Compliance and enforcement: air pollution regulation in the U. S. steel industry, Journal of Environmental Economics and Management 31, 96111 , Article No 0034.

Greif, A. (1993), Contract enforceability and economic institutions in early trade: The Maghribi trader's coalition, The American Economic Review.

Guerreiro, R.; Frezatti, F.; Casado, T. (2006) Em busca de um melhor entendimento da contabilidade gerencial através da integração de conceitos da psicologia, cultura organizacional e teoria institucional, Revista de Contabilidade e Finanças da USP.

Guimarães, E. F. (2015) Modelo inclusivo para a universalização do saneamento básico em áreas de vulnerabilidade social. Tese de doutoramento. Escola de Engenharia de São Carlos, Universidade de São Paulo.

Harrison, K. (1995) Is cooperation the answer? Canadian environmental enforcement in comparative context, Journal of Policy Analysis and Management, Vol. 14 No 2, 221244.

Hirschman, A. O. (1977), The passion and the interests. Princeton University Press.

Hodgson, G.M. (2006) What Are Institutions? Journal of Economic Issues, Vol. XL № 1.

INFOCIDADE (2017). Disponível em <http://infocidade.prefeitura.sp.gov.br/>, acessado em 05 de outubro de 2017.

IPEA (2013) Caracterização e quadros de análise comparativa da governança metropolitana no Brasil: arranjos institucionais de gestão metropolitana. Relatório de Pesquisa.

Jorge, M. A. (2012) Estudos de economia do crime para o Estado de Sergipe: uma resenha, Revista de Economia Mackenzie, Vol. $9 \mathrm{~N}^{\mathrm{o}} 2$. 
Khazaee, A. \& Safa, H. H. (2017), Distribution loss reduction in residential and commercial pilots by using AMI system, $24^{\text {rd }}$ International Conference \& Exhibition on Electricity Distribution (CIRED).

Kim, J.; Mahoney, J.T. (2005) Property rights theory, transaction costs theory, and agency theory: an organizational economics approach to strategic management, Managerial and decision economics 26: 223-242.

Kutner, M. H.; Nachtsheim, C. J.; Neter, J. (2004), Applied Linear Regression Models, 4a Ed. Boston: McGraw-Hill, Irwin. 701p.

Labate, D.; Chicco, G.; Giubbini, P.; Piglione, F. (2015), Shape: the load prediction and nontechnical losses modules, $23^{\text {rd }}$ International Conference on Electricity Distribution (CIRED), Lyon, 15-18 June 2015.

Laville, C.; Dionne, J. (1999) A construção do saber: manual de metodologia da pesquisa em ciências humanas, tradução Heloísa Monteiro e Francisco Settineri, Porto Alegre, Artmed; Belo Horizonte, Editora UFMG.

Leal, R. (2009) O controle social dos serviços públicos no Brasil como condição de sua possibilidade, AFDUDC, 13, 301-320.

Libecap, G. D. (2016) Cosean bargaining to address environmental externalities, Working Paper 21903, disponivel em: http://www.nber.org/papers/w21903.

Littleton, A. C. (1927) The antecedents of double-entry, Accounting Review, Vol. 2, No 2.

Lumineau, F. (2014) How contracts influence both trust and distrust outcomes, Working Paper.

Macedo Jr., R. P. (2007) Contratos relacionais e defesa do usuário. 2a Edição, Editora Revista dos Tribunais.

Macneil, I. (1985) Relational contract: what we do and do not know, Hein Online, Wis.L. Rev. 483.

Manski, C. F. (1995) Identification problems in the social sciences, Harvard University Press.

Manzetti, L.; Rufin, C. (2006) Private utility supply in a hostile environment: the experience of water, sanitation and electricity distribution utilities in Northern Colombia, the Dominican Republic and Ecuador, in Best Practices Series, Sustainable Development Department, Inter-American Development Bank, Washington D.C. 
Marino, M. K. (2005) Implementação de estratégias de governança: um estudo de múltiplas firmas de distribuição de defensivos agrícolas no Brasil. Tese de doutorado - PPGA, Universidade de São Paulo.

Martins, G. A. e Theóphilo, C. R. (2009), Metodologia da Investigação Científica para Ciências Sociais Aplicadas, $2^{\text {a }}$ Edição. São Paulo: Atlas.

Maximiliano, C. (1957) Hermenêutica e aplicação do direito. Rio de Janeiro, Freitas Bastos.

Mattessich, R. (2008) Two hundred years of accounting research, in Routledge new works in accounting history, edited by G. Carnegie, J. R. Edwards, S. Carmona and D. Fleishman.

Nee, V. (1998), Norms and networks in economic and organizational performance, The American Economic Review, Vol. 88, No 2, pp. 85-89.

Nelson, R.R.; Sampat, B. (2001) Making sense of institutions as a factor shaping economic performance, Journal of Economic Behavior \& Organization, Vol. 44, 31-54.

North, D. C. (1990) Institutions, institutional change and economic performance, Cambridge University Press.

Ostrom, E. (1990) Governing the Commons: The Evolution of Institutions for Collective Action. Cambridge University Press.

Pande, R.; Udry, C. (2005) Institutions and development: a view from below, Center discussion paper // Economic Growth Center, No 928.

Passini, S. R. R. \& Toledo, c. M. T. (2002), Mineração de dados para detecção de fraudes em ligações de água, XI SEMINCO.

Paula, G. A. (2013), Modelos de Regressão com apoio Computacional. Disponível em < https://www.ime.usp.br/ giapaula/texto_2013.pdf>, acessado em 05 de outubro de 2017.

Posner, E. (2000) Economic analysis of contract law after three decades: success of failure? Working paper No. 146, The law school of the University of Chicago.

Rocha, A. V. M. A.; Guerreiro, R. (2011) Eficiência de uma empresa de serviços públicos em face do advento da agência reguladora sob a ótica da economia dos custos de transação. Dissertação de mestrado, PPGCC, Universidade de São Paulo. 
Rodrigues, A. M. . (2006) A teoria dos arquivos e a gestão de documentos, Perispect. Cienc. Inf., Belo Horizonte, Vol. 1, p.102-117.

Rodrigues, R. I., (2005) O lugar dos pobres e a violência na cidade: um estudo para o município de São Paulo, IPEA, ANPEC.

Rodrik, D. (2003) Growth strategies, Harvard University, John F. Kennedy School of Governament. http://econ.ucsd.edu/seminars/draft_30.pdf.

Ropaul, M. (2010) Active role of firms in the design of legal norms and acceptability of law. Working paper presented in ESNIE, Cargèse, França.

Rudd, M. A. (2000) Live long and prosper: collective action, social capital and social vision. Ecological Economics, 2000.

Santos, M. F. (2011), Práticas ilegais dos consumidores: uma análise do "gato" na rede de energia elétrica, Revista Brasileira de Marketing, São Paulo, Vol. 10, № 2, p 03-29.

SEADE (2017). Disponível em <http://www.imp.seade.gov.br/frontend/\#/tabelas>, acessado em 05 de outubro de 2017.

Searle, J. R. (2005), What is an institution?, Journal of Institutional Economics, 1: 1, 1-22.

Selznick, P. (1996) Institutionalism “Old" and "New", Administrative Science Quarterly, 41, 270-277.

Shubik, M. (2011), A Note on Accounting and Economic Theory: Past, Present and Future, in Accounting, Economics and Law, Volume 1, Issue 1

Smith, T. B. (2004), Electricity theft: a comparative analysis, Energy Policy 32, 2067-2076.

Souza, G. O. C.; Torres, H. G. (2003), O estudo da metrópole e o uso de informações georreferenciadas. São Paulo em Perspectiva, Vol. 17, № 34.

Wang, H. \& Wheeler, D. (2005), Financial incentives and endougenous enforcement in China's pollution levy system, Journal of Environmental Economics and Management 49, 174-196.

Williamson, O. E. (1979) Transaction-cost economics: the governance of contractual relations, Journal of Law and Economics, Vol. $22 \mathrm{~N}^{\mathrm{o}} 2$ pp.233-261.

Williamson, O. E. (1985) The economic institutions of capitalism: firms, markets, relational contracting. New York: Free Press. 
Williamson, O. E. (1991) Comparative economic organization: the analysis of discrete structure alternatives, Administrative Science Quarterly, Vol. $36 \mathrm{~N}^{\mathrm{o}} 2$.

Winther, T. (2012) Electricity theft as a relational issue: a comparative look at Zanzibar, Tanzania, and the Sunderban Islands, India, Energy for Sustainable Development 16, 111-119.

Wooldridge, J. M. (2002) - Econometric Analysis of Cross Section and Panel Data. The MIT Press. Cambridge, Massachusetts. London, England. 


\section{APÊNDICE A}

Tabela A.1 Quantidade de fraudes por RGI

\begin{tabular}{|c|c|c|c|}
\hline $\begin{array}{l}\text { Quantidade de } \\
\text { fraudes }\end{array}$ & Quantidade de RGIs & Total de fraudes & $\%$ de RGIs \\
\hline 1 & 91.170 & 91.170 & $90,019 \%$ \\
\hline 2 & 7.705 & 15.410 & $7,608 \%$ \\
\hline 3 & 1.547 & 4.641 & $1,527 \%$ \\
\hline 4 & 458 & 1.832 & $0,452 \%$ \\
\hline 5 & 193 & 965 & $0,191 \%$ \\
\hline 6 & 94 & 564 & $0,093 \%$ \\
\hline 7 & 46 & 322 & $0,045 \%$ \\
\hline 8 & 29 & 232 & $0,029 \%$ \\
\hline 9 & 11 & 99 & $0,011 \%$ \\
\hline 10 & 10 & 100 & $0,010 \%$ \\
\hline 11 & 6 & 66 & $0,006 \%$ \\
\hline 12 & 5 & 60 & $0,005 \%$ \\
\hline 13 & 1 & 13 & $0,001 \%$ \\
\hline 17 & 1 & 17 & $0,001 \%$ \\
\hline 21 & 1 & 21 & $0,001 \%$ \\
\hline 22 & 1 & 22 & $0,001 \%$ \\
\hline 31 & 1 & 31 & $0,001 \%$ \\
\hline Total & 101.279 & 115.565 & $100,000 \%$ \\
\hline
\end{tabular}


Tabela A.2. RGIs reincidentes com mais de 10 fraudes $x$ BOs

\begin{tabular}{|c|c|c|c|}
\hline RGI & $\begin{array}{l}\text { Quantidade de } \\
\text { fraudes }\end{array}$ & Distrito & $\begin{array}{c}\text { Categoria de uso/tipo de } \\
\text { tarifa/ramo/BO }\end{array}$ \\
\hline 544657101 & 31 & F. Morato & Residencial/popular/unifamiliar/N \\
\hline 167708112 & 22 & Brasilândia & Residencial/normal/unifamiliar/N \\
\hline 180068687 & 21 & V Cachoeirinha & Residencial/normal/unifamiliar/N \\
\hline 601544200 & 17 & Jardim Ângela & Residencial/normal/unifamiliar/N \\
\hline 111834708 & 13 & Jaraguá & Residencial/normal/Cond.Horiz/N \\
\hline 102051607 & 12 & Mandaqui & Residencial/normal/unifamiliar/N \\
\hline 155134833 & 12 & Artur Alvim & Residencial/normal/unifamiliar/N \\
\hline 167707817 & 12 & Brasilândia & Residencial/normal/unifamiliar/N \\
\hline 224867474 & 12 & Itaquera & Residencial/popular/unifamiliar/S \\
\hline 239210646 & 12 & Jaçanã & Residencial/normal/unifamiliar/N \\
\hline 155134914 & 11 & Artur Alvim & Residencial/normal/unifamiliar/N \\
\hline 221885170 & 11 & Cidade Líder & Residencial/normal/unifamiliar/N \\
\hline 239987845 & 11 & Vila Medeiros & Residencial/popular/cortiço/N \\
\hline 423954458 & 11 & Itaquaquecetuba & Residencial/normal/unifamiliar/N \\
\hline 431178569 & 11 & Itaquaquecetuba & Residencial/normal/unifamiiliar/N \\
\hline 510313531 & 11 & F. da Rocha & Residencial/popular/unifamiliar/N \\
\hline 98792504 & 10 & Tremembé & Residencial/normal/unifamiliar/N \\
\hline 99296306 & 10 & Santana & Residencial/normal/unifamiliar/N \\
\hline 115363300 & 10 & São Domingos & Residencial/normal/unifamiliar/N \\
\hline 115756973 & 10 & São Domingos & Residencial/normal/unifamiliar/N \\
\hline 167707655 & 10 & Brasilândia & Residencial/normal/unifamiliar/N \\
\hline 175746923 & 10 & Limão & Residencial/normal/unifamiliar/N \\
\hline 178096148 & 10 & Brasilândia & Residencial/normal/unifamiliar/N \\
\hline 228603471 & 10 & Cid. Tiradentes & Residencial/normal/unifamiliar/N \\
\hline 236922432 & 10 & Vila Medeiros & Residencial/normal/unifamiliar/N \\
\hline 442709170 & 10 & Brasilândia & Residencial/normal/unifamiliar/N \\
\hline Total & 330 & & \\
\hline
\end{tabular}


Tabela A.3 Fraudes por município - RGIs reincidentes

\begin{tabular}{l|c|c}
\hline \multicolumn{1}{c|}{ Município } & $\begin{array}{c}\text { Quantidade } \\
\text { de fraudes }\end{array}$ & $\%$ \\
\hline Francisco Morato & 31 & $9 \%$ \\
Franco da Rocha & 11 & $3 \%$ \\
Itaquaquecetuba & 22 & $7 \%$ \\
São Paulo & 266 & $81 \%$ \\
\hline \multicolumn{1}{c|}{ Total } & 330 & $100 \%$ \\
\hline
\end{tabular}

Tabela A.4 Fraudes por unidade de negócio - RGIs reincidentes

\begin{tabular}{|c|c|c|}
\hline Unidade de negócio & $\begin{array}{l}\text { Quantidade } \\
\text { de fraudes }\end{array}$ & $\%$ \\
\hline Leste & 78 & $24 \%$ \\
\hline Norte & 235 & $71 \%$ \\
\hline Sul & 17 & $5 \%$ \\
\hline Total & 330 & $100 \%$ \\
\hline
\end{tabular}

Tabela A.5. Fraudes por atendimento comercial - RGIs reincidentes

\begin{tabular}{|c|c|c|}
\hline Atendimento Comercial & $\begin{array}{l}\text { Quantidade de } \\
\text { fraudes }\end{array}$ & $\%$ \\
\hline Arthur Alvim & 23 & $7 \%$ \\
\hline Campo Limpo & 17 & $5 \%$ \\
\hline Cidade Tiradentes & 21 & $6 \%$ \\
\hline Francisco Morato & 31 & $9 \%$ \\
\hline Franco da Rocha & 11 & $3 \%$ \\
\hline Freguesia do Ó & 44 & $13 \%$ \\
\hline Guaianazes & 12 & $4 \%$ \\
\hline Itaquaquecetuba & 22 & $7 \%$ \\
\hline Jaçanã & 33 & $10 \%$ \\
\hline Pirituba & 53 & $16 \%$ \\
\hline Santana & 20 & $6 \%$ \\
\hline Vila Nova Cachoeirinha & 43 & $13 \%$ \\
\hline Total & 330 & $100 \%$ \\
\hline
\end{tabular}


Tabela A.6. Fraudes totais por atendimento comercial

\begin{tabular}{|c|c|c|}
\hline Atendimento Comercial & Quantidade de fraudes & $\%$ \\
\hline Americanópolis & 2.564 & $2,2 \%$ \\
\hline Arthur Alvim & 3.085 & $2,7 \%$ \\
\hline Arujá & 293 & $0,3 \%$ \\
\hline Barueri & 1.789 & $1,5 \%$ \\
\hline Biritiba Mirim & 180 & $0,2 \%$ \\
\hline Bragança Paulista & 569 & $0,5 \%$ \\
\hline Butantã & 1.756 & $1,5 \%$ \\
\hline Caieiras & 783 & $0,7 \%$ \\
\hline Cajamar & 782 & $0,7 \%$ \\
\hline Campo Limpo & 3.462 & $3,0 \%$ \\
\hline Capela Do Socorro & 3.343 & $2,9 \%$ \\
\hline Carapicuíba & 2.672 & $2,3 \%$ \\
\hline Cidade Tiradentes & 4.344 & $3,8 \%$ \\
\hline Cotia & 1.502 & $1,3 \%$ \\
\hline Diadema & 90 & $0,1 \%$ \\
\hline Embu & 743 & $0,6 \%$ \\
\hline Embu Guaçu & 181 & $0,2 \%$ \\
\hline Ferraz de Vasconcelos & 1.296 & $1,1 \%$ \\
\hline Francisco Morato & 2.703 & $2,3 \%$ \\
\hline Franco da Rocha & 1.511 & $1,3 \%$ \\
\hline Freguesia do Ó & 4.524 & $3,9 \%$ \\
\hline Grajaú & 1.952 & $1,7 \%$ \\
\hline Guaianazes & 2.861 & $2,5 \%$ \\
\hline Ipiranga & 1.788 & $1,5 \%$ \\
\hline Itaim Paulista & 4.849 & $4,2 \%$ \\
\hline Itapecerica da Serra & 567 & $0,5 \%$ \\
\hline Itapevi & 1.700 & $1,5 \%$ \\
\hline Itaquaquecetuba & 4.770 & $4,1 \%$ \\
\hline Jaçanã & 1.666 & $1,4 \%$ \\
\hline Jandira & 932 & $0,8 \%$ \\
\hline Jardins & 803 & $0,7 \%$ \\
\hline Joanópolis & 23 & $0,0 \%$ \\
\hline Mairiporã & 328 & $0,3 \%$ \\
\hline Moóca & 2.053 & $1,8 \%$ \\
\hline Nazaré Paulista & 45 & $0,0 \%$ \\
\hline Osasco Antonio Agu & 1.922 & $1,7 \%$ \\
\hline Osasco Km 18 & 2.122 & $1,8 \%$ \\
\hline Pedra Bela & 15 & $0,0 \%$ \\
\hline Penha & 3.587 & $3,1 \%$ \\
\hline Perus & 3.887 & $3,4 \%$ \\
\hline Pinhalzinho & 12 & $0,0 \%$ \\
\hline
\end{tabular}




\begin{tabular}{l|c|c}
\hline \multicolumn{1}{c|}{ Atendimento Comercial } & Quantidade de fraudes & $\%$ \\
\hline Piracaia & 70 & $0,1 \%$ \\
Pirajussara & 1.250 & $1,1 \%$ \\
Pirapora Do Bom Jesus & 367 & $0,3 \%$ \\
Pirituba & 5.793 & $5,0 \%$ \\
Poa & 992 & $0,9 \%$ \\
Ribeirão Pires & 223 & $0,2 \%$ \\
Rio Grande Da Serra & 80 & $0,1 \%$ \\
Salesópolis & 9 & $0,0 \%$ \\
Santana & 4.756 & $4,1 \%$ \\
Santana Do Parnaíba & 802 & $0,7 \%$ \\
Santo Amaro & 2.592 & $2,2 \%$ \\
São Bernardo Do Campo & 3.135 & $2,7 \%$ \\
São Mateus & 2.679 & $2,3 \%$ \\
São Miguel & 5.194 & $4,5 \%$ \\
Sé & 2.413 & $2,1 \%$ \\
Socorro & 50 & $0,0 \%$ \\
Suzano & 2.672 & $2,3 \%$ \\
Taboão Da Serra & 1.148 & $1,0 \%$ \\
Vargem & 11 & $0,0 \%$ \\
Vargem Grande Paulista & 114 & $0,1 \%$ \\
Vila Maria & 1.800 & $1,6 \%$ \\
Vila Mariana & 887 & $0,8 \%$ \\
Vila Nova Cachoeirinha & 4.474 & $3,9 \%$ \\
\hline Total & 115.565 & $100 \%$ \\
\hline
\end{tabular}


Tabela A.7. Fraudes residenciais por 1000 habitantes - nível distrital

\begin{tabular}{|c|c|c|c|}
\hline Distrito & População & $\begin{array}{c}\text { Quantidade de } \\
\text { fraudes Residenciais }\end{array}$ & Fraudes/1000hab \\
\hline Cajamar & 11.589 & 708 & 61,1 \\
\hline São Miguel & 92.081 & 2.334 & 25,3 \\
\hline Socorro & 37.783 & 869 & 23,0 \\
\hline Pirapora do Bom Jesus & 15.733 & 355 & 22,6 \\
\hline Perus & 80.187 & 1.478 & 18,4 \\
\hline São Domingos & 84.843 & 1.490 & 17,6 \\
\hline Francisco Morato & 154.472 & 2.597 & 16,8 \\
\hline Brasilândia & 264.918 & 4.248 & 16,0 \\
\hline Suzano & 155.804 & 2.426 & 15,6 \\
\hline Cachoeirinha & 143.523 & 2.131 & 14,8 \\
\hline Itaquaquecetuba & 321.770 & 4.515 & 14,0 \\
\hline Vila Medeiros & 129.919 & 1.762 & 13,6 \\
\hline Barueri & 112.726 & 1.512 & 13,4 \\
\hline Guaianases & 103.996 & 1.373 & 13,2 \\
\hline Jaçanã & 94.609 & 1.152 & 12,2 \\
\hline Cidade Tiradentes & 211.501 & 2.538 & 12,0 \\
\hline Itaim Paulista & 224.074 & 2.649 & 11,8 \\
\hline Freguesia do Ó & 142.327 & 1.650 & 11,6 \\
\hline Tremembé & 197.258 & 2.283 & 11,6 \\
\hline Anhanguera & 65.859 & 744 & 11,3 \\
\hline Franco da Rocha & 131.604 & 1.412 & 10,7 \\
\hline Carapicuíba & 230.112 & 2.425 & 10,5 \\
\hline Jaraguá & 184.818 & 1.879 & 10,2 \\
\hline Ferraz de Vasconcelos & 120.194 & 1.181 & 9,8 \\
\hline Penha & 127.820 & 1.241 & 9,7 \\
\hline Artur Alvim & 105.269 & 1.002 & 9,5 \\
\hline Limão & 80.229 & 758 & 9,4 \\
\hline Casa Verde & 85.624 & 742 & 8,7 \\
\hline Pedreira & 144.317 & 1.250 & 8,7 \\
\hline Poá & 100.546 & 854 & 8,5 \\
\hline Caieiras & 86.529 & 721 & 8,3 \\
\hline Jaguara & 24.895 & 205 & 8,2 \\
\hline Vila Jacuí & 142.372 & 1.155 & 8,1 \\
\hline Pirituba & 167.931 & 1.362 & 8,1 \\
\hline Vila Curuçá & 149.053 & 1.190 & 8,0 \\
\hline Cotia & 170.513 & 1.359 & 8,0 \\
\hline Jandira & 108.344 & 836 & 7,7 \\
\hline Jardim Helena & 135.043 & 1.004 & 7,4 \\
\hline Vila Maria & 113.463 & 833 & 7,3 \\
\hline Lajeado & 164.512 & 1.204 & 7,3 \\
\hline Itapevi & 200.769 & 1.425 & 7,1 \\
\hline
\end{tabular}


"continuação"

\begin{tabular}{|c|c|c|c|}
\hline Distrito & População & $\begin{array}{c}\text { Quantidade de } \\
\text { fraudes Residenciais }\end{array}$ & Fraudes/1000hab \\
\hline Santana de Parnaíba & 108.813 & 751 & 6,9 \\
\hline Parque do Carmo & 68.258 & 446 & 6,5 \\
\hline Itaquera & 204.871 & 1.306 & 6,4 \\
\hline Vargem Grande Paulista & 42.997 & 274 & 6,4 \\
\hline Grajaú & 360.787 & 2.267 & 6,3 \\
\hline Cidade Lider & 126.597 & 787 & 6,2 \\
\hline Campo Limpo & 211.361 & 1.308 & 6,2 \\
\hline Biritiba-Mirim & 28.575 & 169 & 5,9 \\
\hline Cangaíba & 136.623 & 779 & 5,7 \\
\hline Cidade Kemel & 5467 & 31 & 5,7 \\
\hline Cidade Dutra & 196.360 & 1.084 & 5,5 \\
\hline Vila Matilde & 104.947 & 579 & 5,5 \\
\hline Taboão da Serra & 244.528 & 1.347 & 5,5 \\
\hline Ermelino Matarazzo & 113.615 & 600 & 5,3 \\
\hline Sé & 23.651 & 124 & 5,2 \\
\hline Osasco & 666.740 & 3.482 & 5,2 \\
\hline Tucuruvi & 98.438 & 500 & 5,1 \\
\hline Mandaqui & 107.580 & 546 & 5,1 \\
\hline Pari & 17.299 & 87 & 5,0 \\
\hline Iguatemi & 127.662 & 634 & 5,0 \\
\hline Belém & 45.057 & 219 & 4,9 \\
\hline Mairiporã & 63.265 & 306 & 4,8 \\
\hline Ponte Rasa & 93.894 & 454 & 4,8 \\
\hline Vila Guilherme & 54.331 & 261 & 4,8 \\
\hline Jardim Ângela & 295.434 & 1.392 & 4,7 \\
\hline Brás & 29.265 & 130 & 4,4 \\
\hline Raposo Tavares & 100.164 & 418 & 4,2 \\
\hline Ipiranga & 106.865 & 434 & 4,1 \\
\hline Cidade Ademar & 266.681 & 1.018 & 3,8 \\
\hline Parelheiros & 131.183 & 493 & 3,8 \\
\hline José Bonifácio & 124.122 & 429 & 3,5 \\
\hline Butantã & 54.196 & 185 & 3,4 \\
\hline Embu-Guaçu & 43.106 & 146 & 3,4 \\
\hline Bragança Paulista & 146.744 & 496 & 3,4 \\
\hline São Bernardo do Campo & 736.161 & 2.484 & 3,4 \\
\hline Arujá & 74.905 & 251 & 3,4 \\
\hline Aricanduva & 89.622 & 285 & 3,2 \\
\hline Jabaquara & 223.780 & 706 & 3,2 \\
\hline Sacomã & 247.851 & 771 & 3,1 \\
\hline Carrão & 83.281 & 259 & 3,1 \\
\hline Vila Prudente & 104.242 & 322 & 3,1 \\
\hline São Rafael & 143.992 & 442 & 3,1 \\
\hline
\end{tabular}


"continuação"

\begin{tabular}{|c|c|c|c|}
\hline Distrito & População & $\begin{array}{c}\text { Quantidade de } \\
\text { fraudes Residenciais }\end{array}$ & Fraudes/1000hab \\
\hline Bom Retiro & 33.892 & 104 & 3,1 \\
\hline Sapopemba & 284.524 & 867 & 3,0 \\
\hline Cambuci & 36.948 & 112 & 3,0 \\
\hline Rio Pequeno & 118.459 & 343 & 2,9 \\
\hline Capão Redondo & 268.729 & 757 & 2,8 \\
\hline Cursino & 109.088 & 302 & 2,8 \\
\hline São Mateus & 155.140 & 426 & 2,7 \\
\hline Santana & 118.797 & 326 & 2,7 \\
\hline Ribeirão Pires & 77.986 & 193 & 2,5 \\
\hline Itapecerica da Serra & 152.614 & 367 & 2,4 \\
\hline Jardim São Luís & 267.871 & 640 & 2,4 \\
\hline Vila Formosa & 94.799 & 223 & 2,4 \\
\hline São Lucas & 142.347 & 323 & 2,3 \\
\hline Nazaré Paulista & 16.414 & 37 & 2,3 \\
\hline Liberdade & 69.092 & 155 & 2,2 \\
\hline Embu & 240.230 & 523 & 2,2 \\
\hline Piracaia & 25.116 & 54 & 2,2 \\
\hline Jaguaré & 49.863 & 106 & 2,1 \\
\hline Vila Sônia & 108.441 & 221 & 2,0 \\
\hline Água Rasa & 84.963 & 162 & 1,9 \\
\hline Pedra Bela & 5.780 & 11 & 1,9 \\
\hline Rio Grande da Serra & 43.974 & 75 & 1,7 \\
\hline Joanópolis & 11.768 & 20 & 1,7 \\
\hline Campo Grande & 100.713 & 166 & 1,6 \\
\hline Campo Belo & 65.752 & 105 & 1,6 \\
\hline Santo Amaro & 71.560 & 105 & 1,5 \\
\hline Lapa & 65.739 & 88 & 1,3 \\
\hline Mooca & 75.724 & 97 & 1,3 \\
\hline Vargem & 8.801 & 11 & 1,2 \\
\hline Vila Leopoldina & 39.485 & 46 & 1,2 \\
\hline Tatuapé & 91.672 & 102 & 1,1 \\
\hline Vila Mariana & 130.484 & 136 & 1,0 \\
\hline Morumbi & 46.957 & 47 & 1,0 \\
\hline Santa Cecília & 83.717 & 76 & 0,9 \\
\hline Itaim Bibi & 92.570 & 81 & 0,9 \\
\hline Marsilac & 8.258 & 7 & 0,8 \\
\hline Saúde & 130.780 & 101 & 0,8 \\
\hline Pinhalzinho & 13.105 & 10 & 0,8 \\
\hline Alto de Pinheiros & 43.117 & 29 & 0,7 \\
\hline Perdizes & 111.161 & 72 & 0,6 \\
\hline Salesópolis & 12.479 & 8 & 0,6 \\
\hline Bela Vista & 69.460 & 44 & 0,6 \\
\hline
\end{tabular}




\begin{tabular}{l|c|c|c}
\hline \multicolumn{1}{c|}{ Distrito } & População & $\begin{array}{c}\text { Quantidade de } \\
\text { fraudes Residenciais }\end{array}$ & Fraudes/1000hab \\
\hline República & 56.981 & 32 & 0,6 \\
Barra Funda & 14.383 & 8 & 0,6 \\
Pinheiros & 65.364 & 23 & 0,4 \\
Vila Andrade & 127.015 & 41 & 0,3 \\
Pirajussara & 244.528 & 56 & 0,2 \\
Moema & 83.368 & 18 & 0,2 \\
Consolação & 57.365 & 7 & 0,1 \\
Jardim Paulista & 88.692 & 9 & 0,1 \\
Batatuba & - & 3 & 0,0 \\
Sem informação & - & 59 & 0,0 \\
\hline Total & $\mathbf{1 6 . 1 8 8 . 3 0 4}$ & $\mathbf{9 9 . 7 2 6}$ & $\mathbf{8 1 3}$ \\
\hline
\end{tabular}

Tabela A.8. Fraudes totais por unidade de negócio

\begin{tabular}{|c|c|c|}
\hline Unidade de Negócio & Quantidade de fraudes & $\%$ \\
\hline Centro & 10.623 & $9 \%$ \\
\hline Leste & 34.132 & $30 \%$ \\
\hline Norte & 33.802 & $29 \%$ \\
\hline Oeste & 18.076 & $16 \%$ \\
\hline Sul & 18.932 & $16 \%$ \\
\hline Total & 115.565 & $100 \%$ \\
\hline
\end{tabular}


Tabela A.9. Fraudes residenciais por 1000 habitantes - nível município

\begin{tabular}{|c|c|c|c|c|}
\hline Município & População & $\begin{array}{c}\text { Quantidade de } \\
\text { fraudes residenciais }\end{array}$ & $\begin{array}{c}\text { Fraudes } / 1000 \\
\text { hab }\end{array}$ & $\%$ \\
\hline Pirapora Do Bom Jesus & 15.733 & 355 & 22,6 & $0,4 \%$ \\
\hline Francisco Morato & 154.472 & 2.589 & 16,8 & $2,6 \%$ \\
\hline Itaquaquecetuba & 321.770 & 4.488 & 13,9 & $4,5 \%$ \\
\hline Cajamar & 64.114 & 710 & 11,1 & $0,7 \%$ \\
\hline Franco Da Rocha & 131.604 & 1.419 & 10,8 & $1,4 \%$ \\
\hline Suzano & 262.480 & 2.423 & 9,2 & $2,4 \%$ \\
\hline Poá & 106.013 & 904 & 8,5 & $0,9 \%$ \\
\hline Caieiras & 86.529 & 720 & 8,3 & $0,7 \%$ \\
\hline Itapevi & 200.769 & 1.593 & 7,9 & $1,6 \%$ \\
\hline Jandira & 108.344 & 835 & 7,7 & $0,8 \%$ \\
\hline Ferraz De Vasconcelos & 168.306 & 1.186 & 7,0 & $1,2 \%$ \\
\hline Santana De Parnaíba & 108.813 & 743 & 6,8 & $0,7 \%$ \\
\hline Cotia & 201.150 & 1.360 & 6,8 & $1,4 \%$ \\
\hline Carapicuíba & 369.584 & 2.423 & 6,6 & $2,4 \%$ \\
\hline Barueri & 240.749 & 1.528 & 6,3 & $1,5 \%$ \\
\hline Biritiba-Mirim & 28.575 & 169 & 5,9 & $0,2 \%$ \\
\hline São Paulo & 11.253 .503 & 66.459 & 5,9 & $66,6 \%$ \\
\hline Osasco & 666.740 & 3.480 & 5,2 & $3,5 \%$ \\
\hline Taboão Da Serra & 244.528 & 982 & 4,0 & $1,0 \%$ \\
\hline Mairiporã & 80.956 & 306 & 3,8 & $0,3 \%$ \\
\hline Bragança Paulista & 146.744 & 496 & 3,4 & $0,5 \%$ \\
\hline Arujá & 74.905 & 253 & 3,4 & $0,3 \%$ \\
\hline São Bernardo Do Campo & 765.463 & 2.486 & 3,2 & $2,5 \%$ \\
\hline Itapecerica Da Serra & 152.614 & 484 & 3,2 & $0,5 \%$ \\
\hline Embu & 240.230 & 618 & 2,6 & $0,6 \%$ \\
\hline Vargem Grande Paulista & 42.997 & 103 & 2,4 & $0,1 \%$ \\
\hline Embu-Guaçu & 62.769 & 146 & 2,3 & $0,1 \%$ \\
\hline Piracaia & 25.116 & 57 & 2,3 & $0,1 \%$ \\
\hline Nazaré Paulista & 16.414 & 37 & 2,3 & $0,0 \%$ \\
\hline Pedra Bela & 5.780 & 11 & 1,9 & $0,0 \%$ \\
\hline Ribeirão Pires & 113.068 & 193 & 1,7 & $0,2 \%$ \\
\hline Rio Grande Da Serra & 43.974 & 75 & 1,7 & $0,1 \%$ \\
\hline Joanópolis & 11.768 & 20 & 1,7 & $0,0 \%$ \\
\hline Vargem & 8.801 & 11 & 1,2 & $0,0 \%$ \\
\hline Socorro & 36.686 & 41 & 1,1 & $0,0 \%$ \\
\hline Pinhalzinho & 13.105 & 12 & 0,9 & $0,0 \%$ \\
\hline Salesópolis & 15.635 & 8 & 0,5 & $0,0 \%$ \\
\hline Diadema & 386.089 & 65 & 0,2 & $0,1 \%$ \\
\hline TOTAL & & 99.788 & & $100,0 \%$ \\
\hline
\end{tabular}


Tabela A.10. Fraudes totais por categoria de uso

\begin{tabular}{l|c|c}
\hline \multicolumn{1}{c|}{ Categoria } & $\begin{array}{c}\text { Quantidade de } \\
\text { fraudes }\end{array}$ & $\%$ \\
\hline Comercial & 10.487 & $9 \%$ \\
Industrial & 1.476 & $1 \%$ \\
Mista & 3.731 & $3 \%$ \\
Pública & 83 & $0 \%$ \\
Residencial & 99.788 & $86 \%$ \\
\hline Total & 115.565 & $100 \%$ \\
\hline
\end{tabular}

Tabela A.11. Fraudes totais por ramo de atividade

\begin{tabular}{|c|c|c|}
\hline Ramo de atividade & $\begin{array}{l}\text { Quantidade } \\
\text { de fraudes }\end{array}$ & $\%$ \\
\hline Residência unifamiliar & 89.242 & $77,22 \%$ \\
\hline Condomínios residenciais horizontais & 8.297 & $7,18 \%$ \\
\hline Estabelecimentos de serviços de alimentação & 4.435 & $3,84 \%$ \\
\hline Comercio varejo reparo de objetos pessoais e domésticos & 2.435 & $2,11 \%$ \\
\hline Comércio e reparo de veículos e varejo combustível & 2.059 & $1,78 \%$ \\
\hline Favela & 1.535 & $1,33 \%$ \\
\hline Indefinido e não identificado & 1.067 & $0,92 \%$ \\
\hline Serviços pessoais & 756 & $0,65 \%$ \\
\hline Fabricação de produtos alimentícios e bebidas & 581 & $0,50 \%$ \\
\hline Outras atividades associativas & 550 & $0,48 \%$ \\
\hline Armazéns e terminais & 503 & $0,44 \%$ \\
\hline Comércio por atacado e intermediários do comercio & 479 & $0,41 \%$ \\
\hline Outras atividades sociais e esportivas & 466 & $0,40 \%$ \\
\hline Saúde e serviços sociais & 364 & $0,31 \%$ \\
\hline $\begin{array}{l}\text { Serviços prestados a empresas de advocacia contábil. auditoria. } \\
\text { engenharia e outros }\end{array}$ & 352 & $0,30 \%$ \\
\hline Educação & 293 & $0,25 \%$ \\
\hline Cortiço & 280 & $0,24 \%$ \\
\hline Construção & 229 & $0,20 \%$ \\
\hline Fabricação de produtos de metal exceto maquinas e equipamentos & 203 & $0,18 \%$ \\
\hline Condomínios residenciais verticais & 174 & $0,15 \%$ \\
\hline Condomínios Comerciais & 152 & $0,13 \%$ \\
\hline Fabricação de moveis e indústrias diversas & 120 & $0,10 \%$ \\
\hline Confecção de artigos de vestuário e acessórios & 116 & $0,10 \%$ \\
\hline Cingapura & 84 & $0,07 \%$ \\
\hline CDHU & 69 & $0,06 \%$ \\
\hline Metalurgia básica & 63 & $0,05 \%$ \\
\hline Fabricação de artigos de madeira & 57 & $\begin{array}{l}0,05 \% \\
\text { "continua" }\end{array}$ \\
\hline
\end{tabular}




\begin{tabular}{|c|c|c|}
\hline Ramo de atividade & $\begin{array}{l}\text { Quantidade } \\
\text { de fraudes }\end{array}$ & $\%$ \\
\hline Fabricação de produtos minerais não metálicos & 57 & $0,05 \%$ \\
\hline $\begin{array}{l}\text { Serviços coletivos prestados pela administração pública e serviços } \\
\text { sociais }\end{array}$ & 55 & $0,05 \%$ \\
\hline Fabricação de artigos de borracha e plástico & 48 & $0,04 \%$ \\
\hline Intermediários financeiros. seguradoras e previdência privada & 47 & $0,04 \%$ \\
\hline Edição impressão e reprodução de gravações & 45 & $0,04 \%$ \\
\hline Aluguel e locação & 40 & $0,03 \%$ \\
\hline Cohab & 39 & $0,03 \%$ \\
\hline Fabricação de produtos têxteis & 38 & $0,03 \%$ \\
\hline Fabricação de maquinas e equipamentos & 32 & $0,03 \%$ \\
\hline Consultoria & 28 & $0,02 \%$ \\
\hline Reciclagem & 28 & $0,02 \%$ \\
\hline Fabricação de celulose. papel e produtos de papel & 26 & $0,02 \%$ \\
\hline Fabricação de aparelhos e materiais elétricos & 18 & $0,02 \%$ \\
\hline Fabricação de produtos químicos & 18 & $0,02 \%$ \\
\hline Correio e telecomunicações & 12 & $0,01 \%$ \\
\hline Fabricação de couro. artigos para viagem e calçados & 12 & $0,01 \%$ \\
\hline Fabricação de veículos automotores reboque e carrocerias & 12 & $0,01 \%$ \\
\hline Equipamentos médicos hospitalares de precisão óticos & 9 & $0,01 \%$ \\
\hline Condomínios mistos. residência e comércio & 8 & $0,01 \%$ \\
\hline Extração de minerais não metálicos & 7 & $0,01 \%$ \\
\hline Limpeza urbana. esgoto e atividades conexas & 7 & $0,01 \%$ \\
\hline Fabricação de materiais eletrônicos e aparelhos de comunicação & 6 & $0,01 \%$ \\
\hline Captação tratamento e distribuição de água & 3 & $0,00 \%$ \\
\hline Eletricidade. gás e água quente & 3 & $0,00 \%$ \\
\hline Agrícola & 2 & $0,00 \%$ \\
\hline Fabricação de outros equipamentos de transporte & 2 & $0,00 \%$ \\
\hline Extração de carvão mineral & 1 & $0,00 \%$ \\
\hline Extração de minerais metálicos & 1 & $0,00 \%$ \\
\hline Total & 115565 & $100,0 \%$ \\
\hline
\end{tabular}


Tabela A.12. Fraudes por tipo de tarifa

\begin{tabular}{l|c|c}
\hline \multicolumn{1}{c|}{ Tarifa } & Quantidade de fraudes & $\%$ \\
\hline Assistencial RC & 8 & $0 \%$ \\
Cliente demanda firme faturamento especial & 3 & $0 \%$ \\
Entidade publica com convênio RC & 4 & $0 \%$ \\
Entidade publica RC & 81 & $0 \%$ \\
Normal faturamento especial & 184 & $0 \%$ \\
Normal faturamento especial poço & 9 & $0 \%$ \\
Normal RC & 110.708 & $96 \%$ \\
Normal válvula incêndio & 4 & $0 \%$ \\
Popular e favela RC & 4.558 & $4 \%$ \\
Prédio próprio & 6 & $0 \%$ \\
\hline Total & 115.565 & $100 \%$ \\
\hline
\end{tabular}

Tabela A.13. Fraudes por tipo de ligação

\begin{tabular}{l|c|c}
\hline Tipo de ligação & Quantidade de fraudes & $\%$ \\
\hline Somente água & 25.961 & $22,46 \%$ \\
Água e esgoto & 89.578 & $77,51 \%$ \\
Somente esgoto & 26 & $0,02 \%$ \\
\hline Total & 115.565 & $100,00 \%$ \\
\hline
\end{tabular}

Tabela A.14. Fraudes comerciais por unidade de negócio

\begin{tabular}{l|c|c}
\hline Unidade de negócio & $\begin{array}{c}\text { Quantidade de } \\
\text { fraudes }\end{array}$ & $\%$ \\
\hline Centro & 2662 & $25,4 \%$ \\
Sul & 2462 & $23,5 \%$ \\
Leste & 2129 & $20,3 \%$ \\
Norte & 1875 & $17,9 \%$ \\
Oeste & 1359 & $13,0 \%$ \\
\hline Total & 10.487 & $100 \%$ \\
\hline
\end{tabular}


Tabela A.15. Atendimentos com maior número de fraudes comerciais - município de SP

\begin{tabular}{l|c|c}
\hline \multicolumn{1}{c|}{ Atendimento Comercial } & Quantidade de fraudes & $\%$ \\
\hline Sé & 1193 & $11 \%$ \\
Santo Amaro & 947 & $9 \%$ \\
São Miguel & 505 & $5 \%$ \\
Jardins & 457 & $4 \%$ \\
Penha & 430 & $4 \%$ \\
Santana & 401 & $4 \%$ \\
Mooca & 392 & $4 \%$ \\
Campo Limpo & 341 & $3 \%$ \\
Butantã & 312 & $3 \%$ \\
Capela do Socorro & 275 & $3 \%$ \\
Demais Atendimentos & 5234 & $50 \%$ \\
\hline
\end{tabular}

Tabela A.16. Fraudes na categoria comercial por município e distrito

\begin{tabular}{l|c|c}
\hline \multicolumn{1}{c|}{ Distrito } & $\begin{array}{c}\text { Quantidade de fraudes } \\
\text { Comerciais }\end{array}$ & $\%$ do total \\
\hline São Bernardo do Campo & 416 & $4,0 \%$ \\
São Miguel & 369 & $3,5 \%$ \\
Osasco & 344 & $3,3 \%$ \\
Penha & 294 & $2,8 \%$ \\
Santo Amaro & 289 & $2,8 \%$ \\
Itaim Bibi & 223 & $2,1 \%$ \\
República & 197 & $1,9 \%$ \\
Sé & 194 & $1,8 \%$ \\
Vila Medeiros & 189 & $1,8 \%$ \\
Brás & 170 & $1,6 \%$ \\
Itaim Paulista & 168 & $1,6 \%$ \\
Jabaquara & 158 & $1,5 \%$ \\
Taboão da Serra & 158 & $1,5 \%$ \\
Cidade Ademar & 153 & $1,5 \%$ \\
Barueri & 148 & $1,4 \%$ \\
Carapicuíba & 148 & $1,4 \%$ \\
Cidade Tiradentes & 143 & $1,4 \%$ \\
Grajaú & 135 & $1,3 \%$ \\
Freguesia do Ó & 132 & $1,3 \%$ \\
Suzano & 129 & $1,2 \%$ \\
Artur Alvim & 123 & $1,2 \%$ \\
Campo Belo & 123 & $1,2 \%$ \\
\hline & &
\end{tabular}


"continuação"

\begin{tabular}{|c|c|c|}
\hline Distrito & $\begin{array}{c}\text { Quantidade de fraudes } \\
\text { Comerciais }\end{array}$ & $\%$ do total \\
\hline Santa Cecília & 122 & $1,2 \%$ \\
\hline Jardim Ângela & 120 & $1,1 \%$ \\
\hline Santana & 120 & $1,1 \%$ \\
\hline Socorro & 120 & $1,1 \%$ \\
\hline Jardim São Luís & 119 & $1,1 \%$ \\
\hline Vila Maria & 117 & $1,1 \%$ \\
\hline Vila Nova Cachoeirinha & 116 & $1,1 \%$ \\
\hline Campo Grande & 115 & $1,1 \%$ \\
\hline Itaquaquecetuba & 115 & $1,1 \%$ \\
\hline Bom Retiro & 113 & $1,1 \%$ \\
\hline Ipiranga & 112 & $1,1 \%$ \\
\hline Brasilândia & 98 & $0,9 \%$ \\
\hline Campo Limpo & 97 & $0,9 \%$ \\
\hline Tremembé & 97 & $0,9 \%$ \\
\hline Vila Mariana & 96 & $0,9 \%$ \\
\hline Pinheiros & 94 & $0,9 \%$ \\
\hline Cidade Dutra & 93 & $0,9 \%$ \\
\hline Casa Verde & 89 & $0,8 \%$ \\
\hline Belém & 87 & $0,8 \%$ \\
\hline Vila Prudente & 87 & $0,8 \%$ \\
\hline Liberdade & 86 & $0,8 \%$ \\
\hline Butantã & 84 & $0,8 \%$ \\
\hline Jaraguá & 83 & $0,8 \%$ \\
\hline Sapopemba & 82 & $0,8 \%$ \\
\hline Capão Redondo & 81 & $0,8 \%$ \\
\hline Lapa & 81 & $0,8 \%$ \\
\hline Vila Guilherme & 80 & $0,8 \%$ \\
\hline Pedreira & 79 & $0,8 \%$ \\
\hline Pirituba & 79 & $0,8 \%$ \\
\hline Itaquera & 76 & $0,7 \%$ \\
\hline Vila Leopoldina & 76 & $0,7 \%$ \\
\hline Tatuapé & 72 & $0,7 \%$ \\
\hline Guaianases & 69 & $0,7 \%$ \\
\hline Moema & 69 & $0,7 \%$ \\
\hline Cotia & 68 & $0,6 \%$ \\
\hline São Domingos & 67 & $0,6 \%$ \\
\hline Embu & 66 & $0,6 \%$ \\
\hline Jaçanã & 65 & $0,6 \%$ \\
\hline Vila Curuça & 65 & $0,6 \%$ \\
\hline Limão & 64 & $0,6 \%$ \\
\hline Tucuruvi & 63 & $0,6 \%$ \\
\hline
\end{tabular}


"continuação"

\begin{tabular}{|c|c|c|}
\hline Distrito & $\begin{array}{c}\text { Quantidade de fraudes } \\
\text { Comerciais }\end{array}$ & $\%$ do total \\
\hline Vila Matilde & 63 & $0,6 \%$ \\
\hline Pari & 62 & $0,6 \%$ \\
\hline Cursino & 61 & $0,6 \%$ \\
\hline Bela Vista & 60 & $0,6 \%$ \\
\hline Mooca & 59 & $0,6 \%$ \\
\hline Sacomã & 59 & $0,6 \%$ \\
\hline Vila Sonia & 59 & $0,6 \%$ \\
\hline Cangaíba & 58 & $0,6 \%$ \\
\hline São Matheus & 58 & $0,6 \%$ \\
\hline Cambuci & 57 & $0,5 \%$ \\
\hline Franco da Rocha & 55 & $0,5 \%$ \\
\hline Ponte Rasa & 55 & $0,5 \%$ \\
\hline Saúde & 55 & $0,5 \%$ \\
\hline Vila Jacuí & 54 & $0,5 \%$ \\
\hline Perus & 52 & $0,5 \%$ \\
\hline Bragança Paulista & 51 & $0,5 \%$ \\
\hline Carrão & 51 & $0,5 \%$ \\
\hline Raposo Tavares & 51 & $0,5 \%$ \\
\hline Ferraz de Vasconcelos & 50 & $0,5 \%$ \\
\hline Cajamar & 49 & $0,5 \%$ \\
\hline Ermelino Matarazzo & 49 & $0,5 \%$ \\
\hline Itapevi & 49 & $0,5 \%$ \\
\hline Rio Pequeno & 48 & $0,5 \%$ \\
\hline Consolação & 47 & $0,4 \%$ \\
\hline Poá & 46 & $0,4 \%$ \\
\hline Itapecerica da Serra & 45 & $0,4 \%$ \\
\hline Jardim Paulista & 45 & $0,4 \%$ \\
\hline Perdizes & 45 & $0,4 \%$ \\
\hline Mandaqui & 43 & $0,4 \%$ \\
\hline Aricanduva & 42 & $0,4 \%$ \\
\hline Jandira & 42 & $0,4 \%$ \\
\hline Jardim Helena & 41 & $0,4 \%$ \\
\hline Santana de Parnaíba & 40 & $0,4 \%$ \\
\hline São Lucas & 40 & $0,4 \%$ \\
\hline Jaguaré & 39 & $0,4 \%$ \\
\hline Francisco Morato & 37 & $0,4 \%$ \\
\hline Lajeado & 34 & $0,3 \%$ \\
\hline Vila Formosa & 34 & $0,3 \%$ \\
\hline Cidade Líder & 33 & $0,3 \%$ \\
\hline Parque do Carmo & 33 & $0,3 \%$ \\
\hline Jaguará & 32 & $0,3 \%$ \\
\hline
\end{tabular}


"continuação"

\begin{tabular}{l|c|c}
\hline \multicolumn{1}{c|}{ Distrito } & $\begin{array}{c}\text { Quantidade de fraudes } \\
\text { Comerciais }\end{array}$ & $\%$ do total \\
\hline Anhanguera & 31 & $0,3 \%$ \\
Água Rasa & 30 & $0,3 \%$ \\
Caieiras & 30 & $0,3 \%$ \\
Parelheiros & 29 & $0,3 \%$ \\
Barra Funda & 28 & $0,3 \%$ \\
Iguatemi & 27 & $0,3 \%$ \\
Embu Guaçu & 26 & $0,2 \%$ \\
José Bonifácio & 26 & $0,2 \%$ \\
Arujá & 23 & $0,2 \%$ \\
Morumbi & 23 & $0,2 \%$ \\
Ribeirão Pires & 22 & $0,2 \%$ \\
Pirajussara & 17 & $0,2 \%$ \\
Vargem Grande Paulista & 15 & $0,1 \%$ \\
Vila Andrade & 15 & $0,1 \%$ \\
Mairiporã & 14 & $0,1 \%$ \\
São Rafael & 13 & $0,1 \%$ \\
Alto de Pinheiros & 10 & $0,1 \%$ \\
Sem localização & 10 & $0,1 \%$ \\
Piracaia & 8 & $0,1 \%$ \\
Biritiba Mirim & 6 & $0,1 \%$ \\
Nazaré Paulista & 6 & $0,1 \%$ \\
Pirapora do Bom Jesus & 5 & $0,0 \%$ \\
Rio Grande da Serra & 4 & $0,0 \%$ \\
Pedra Bela & $\mathbf{1 0 4 8 7}$ & $0,0 \%$ \\
\hline Total & & $\mathbf{1 0 0 \%}$ \\
\hline & 500 con \\
\hline
\end{tabular}

"conclusão" 
Tabela A.17. Fraudes na categoria comercial por 1000 habitantes -Município e Distrito

\begin{tabular}{|c|c|c|c|}
\hline Distrito & População & $\begin{array}{l}\text { Quantidade de } \\
\text { fraudes comerciais }\end{array}$ & Fraudes/1000hab \\
\hline Sé & 23.651 & 194 & 8,20 \\
\hline Brás & 29.265 & 170 & 5,81 \\
\hline Cajamar & 11.589 & 49 & 4,23 \\
\hline Santo Amaro & 71.560 & 289 & 4,04 \\
\hline São Miguel & 92.081 & 369 & 4,01 \\
\hline Pari & 17.299 & 62 & 3,58 \\
\hline República & 56.981 & 197 & 3,46 \\
\hline Bom Retiro & 33.892 & 113 & 3,33 \\
\hline Socorro & 37.783 & 120 & 3,18 \\
\hline Itaim Bibi & 92.570 & 223 & 2,41 \\
\hline Penha & 127.820 & 294 & 2,30 \\
\hline Barra Funda & 14.383 & 28 & 1,95 \\
\hline Belém & 45.057 & 87 & 1,93 \\
\hline Vila Leopoldina & 39.485 & 76 & 1,92 \\
\hline Campo Belo & 65.752 & 123 & 1,87 \\
\hline Butantã & 54.196 & 84 & 1,55 \\
\hline Cambuci & 36.948 & 57 & 1,54 \\
\hline Vila Guilherme & 54.331 & 80 & 1,47 \\
\hline Santa Cecília & 83.717 & 122 & 1,46 \\
\hline Vila Medeiros & 129.919 & 189 & 1,45 \\
\hline Pinheiros & 65.364 & 94 & 1,44 \\
\hline Barueri & 112.726 & 148 & 1,31 \\
\hline Jaguara & 24.895 & 32 & 1,29 \\
\hline Liberdade & 69.092 & 86 & 1,24 \\
\hline Lapa & 65.739 & 81 & 1,23 \\
\hline Artur Alvim & 105.269 & 123 & 1,17 \\
\hline Campo Grande & 100.713 & 115 & 1,14 \\
\hline Ipiranga & 106.865 & 112 & 1,05 \\
\hline Casa Verde & 85.624 & 89 & 1,04 \\
\hline Vila Maria & 113.463 & 117 & 1,03 \\
\hline Santana & 118.797 & 120 & 1,01 \\
\hline Freguesia do Ó & 142.327 & 135 & 0,95 \\
\hline Bela Vista & 69.460 & 60 & 0,86 \\
\hline Vila Prudente & 104.242 & 87 & 0,83 \\
\hline Suzano & 155.804 & 129 & 0,83 \\
\hline Moema & 83.368 & 69 & 0,83 \\
\hline Consolação & 57.365 & 47 & 0,82 \\
\hline Vila Nova Cachoeirinha & 143.523 & 116 & 0,81 \\
\hline
\end{tabular}


"continuação"

\begin{tabular}{|c|c|c|c|}
\hline Distrito & População & $\begin{array}{l}\text { Quantidade de } \\
\text { fraudes comerciais }\end{array}$ & Fraudes/1000hab \\
\hline Limão & 80.229 & 64 & 0,80 \\
\hline São Domingos & 84.843 & 67 & 0,79 \\
\hline Tatuapé & 91.672 & 72 & 0,79 \\
\hline Jaguaré & 49.863 & 39 & 0,78 \\
\hline Mooca & 75.724 & 59 & 0,78 \\
\hline Itaim Paulista & 224.074 & 168 & 0,75 \\
\hline Vila Mariana & 130.484 & 96 & 0,74 \\
\hline Jabaquara & 223.780 & 158 & 0,71 \\
\hline Jaçanã & 94.609 & 65 & 0,69 \\
\hline Cidade Tiradentes & 211.501 & 143 & 0,68 \\
\hline Guaianases & 103.996 & 69 & 0,66 \\
\hline Perus & 80.187 & 52 & 0,65 \\
\hline Taboão da Serra & 244.528 & 158 & 0,65 \\
\hline Carapicuíba & 230.112 & 148 & 0,64 \\
\hline Tucuruvi & 98.438 & 63 & 0,64 \\
\hline Carrão & 83.281 & 51 & 0,61 \\
\hline Embu-Guaçu & 43.106 & 26 & 0,60 \\
\hline Vila Matilde & 104.947 & 63 & 0,60 \\
\hline Ponte Rasa & 93.894 & 55 & 0,59 \\
\hline Cidade Ademar & 266.681 & 153 & 0,57 \\
\hline São Bernardo do Campo & 736.161 & 416 & 0,57 \\
\hline Cursino & 109.088 & 61 & 0,56 \\
\hline Pedreira & 144.317 & 79 & 0,55 \\
\hline Vila Sônia & 108.441 & 59 & 0,54 \\
\hline Osasco & 666.740 & 344 & 0,52 \\
\hline Raposo Tavares & 100.164 & 51 & 0,51 \\
\hline Jardim Paulista & 88.692 & 45 & 0,51 \\
\hline Tremembé & 197.258 & 97 & 0,49 \\
\hline Morumbi & 46.957 & 23 & 0,49 \\
\hline Parque do Carmo & 68.258 & 33 & 0,48 \\
\hline Cidade Dutra & 196.360 & 93 & 0,47 \\
\hline Anhanguera & 65.859 & 31 & 0,47 \\
\hline Pirituba & 167.931 & 79 & 0,47 \\
\hline Aricanduva & 89.622 & 42 & 0,47 \\
\hline Campo Limpo & 211.361 & 97 & 0,46 \\
\hline Poá & 100.546 & 46 & 0,46 \\
\hline Jaraguá & 184.818 & 83 & 0,45 \\
\hline Jardim São Luís & 267.871 & 119 & 0,44 \\
\hline Vila Curuçá & 149.053 & 65 & 0,44 \\
\hline Ermelino Matarazzo & 113.615 & 49 & 0,43 \\
\hline
\end{tabular}


"continuação"

\begin{tabular}{|c|c|c|c|}
\hline Distrito & População & $\begin{array}{l}\text { Quantidade de } \\
\text { fraudes comerciais }\end{array}$ & Fraudes/1000hab \\
\hline Cangaíba & 136.623 & 58 & 0,42 \\
\hline Saúde & 130.780 & 55 & 0,42 \\
\hline Franco da Rocha & 131.604 & 55 & 0,42 \\
\hline Ferraz de Vasconcelos & 120.194 & 50 & 0,42 \\
\hline Jardim Ângela & 295.434 & 120 & 0,41 \\
\hline Rio Pequeno & 118.459 & 48 & 0,41 \\
\hline Perdizes & 111.161 & 45 & 0,40 \\
\hline Mandaqui & 107.580 & 43 & 0,40 \\
\hline Cotia & 170.513 & 68 & 0,40 \\
\hline Jandira & 108.344 & 42 & 0,39 \\
\hline Vila Jacuí & 142.372 & 54 & 0,38 \\
\hline Grajaú & 360.787 & 135 & 0,37 \\
\hline São Mateus & 155.140 & 58 & 0,37 \\
\hline Itaquera & 204.871 & 76 & 0,37 \\
\hline Brasilândia & 264.918 & 98 & 0,37 \\
\hline Santana de Parnaíba & 108.813 & 40 & 0,37 \\
\hline Nazaré Paulista & 16.414 & 6 & 0,37 \\
\hline Vila Formosa & 94.799 & 34 & 0,36 \\
\hline Itaquaquecetuba & 321.770 & 115 & 0,36 \\
\hline Água Rasa & 84.963 & 30 & 0,35 \\
\hline Vargem Grande Paulista & 42.997 & 15 & 0,35 \\
\hline Bragança Paulista & 146.744 & 51 & 0,35 \\
\hline Caieiras & 86.529 & 30 & 0,35 \\
\hline Pedra Bela & 5.780 & 2 & 0,35 \\
\hline Piracaia & 25.116 & 8 & 0,32 \\
\hline Pirapora do Bom Jesus & 15.733 & 5 & 0,32 \\
\hline Arujá & 74.905 & 23 & 0,31 \\
\hline Jardim Helena & 135.043 & 41 & 0,30 \\
\hline Capão Redondo & 268.729 & 81 & 0,30 \\
\hline Itapecerica da Serra & 152.614 & 45 & 0,29 \\
\hline Sapopemba & 284.524 & 82 & 0,29 \\
\hline Ribeirão Pires & 77.986 & 22 & 0,28 \\
\hline São Lucas & 142.347 & 40 & 0,28 \\
\hline Embu & 240.230 & 66 & 0,27 \\
\hline Cidade Lider & 126.597 & 33 & 0,26 \\
\hline Itapevi & 200.769 & 49 & 0,24 \\
\hline Francisco Morato & 154.472 & 37 & 0,24 \\
\hline Sacomã & 247.851 & 59 & 0,24 \\
\hline Alto de Pinheiros & 43.117 & 10 & 0,23 \\
\hline Mairiporã & 63.265 & 14 & 0,22 \\
\hline
\end{tabular}


"continuação"

\begin{tabular}{l|c|c|c}
\hline Distrito & População & $\begin{array}{c}\text { Quantidade de } \\
\text { fraudes comerciais }\end{array}$ & Fraudes/1000hab \\
\hline Parelheiros & 131.183 & 29 & 0,22 \\
Iguatemi & 127.662 & 27 & 0,21 \\
Biritiba-Mirim & 28.575 & 6 & 0,21 \\
José Bonifácio & 124.122 & 26 & 0,21 \\
Lajeado & 164.512 & 34 & 0,21 \\
Vila Andrade & 127.015 & 15 & 0,12 \\
Rio Grande da Serra & 43.974 & 4 & 0,09 \\
São Rafael & 143.992 & 13 & 0,09 \\
Pirajussara & 244.528 & 17 & 0,07 \\
Não localizado & 0 & 10 & 0 \\
\hline Total & 16.128 .426 & 10487 & "conclusão"
\end{tabular}

Tabela A.18. Distritos com maior proporção de fraudes comerciais comparativamente às fraudes residenciais $/ \mathbf{1 0 0 0}$ hab.

\begin{tabular}{l|c|c|c|c|c}
\hline \multicolumn{1}{c|}{ Distrito } & População & $\begin{array}{c}\text { Quantidade de } \\
\text { fraudes } \\
\text { comerciais }\end{array}$ & $\begin{array}{c}\text { Fraudes } \\
\text { comerciais/1000hab }\end{array}$ & $\begin{array}{c}\text { Quantidade de } \\
\text { fraudes } \\
\text { residenciais }\end{array}$ & $\begin{array}{c}\text { Fraudes } \\
\text { residenciais/1000hab }\end{array}$ \\
\hline Sé & 23.651 & 194 & 8,2 & 124 & 5,2 \\
República & 56.981 & 197 & 3,5 & 32 & 0,6 \\
Santo Amaro & 71.560 & 289 & 4,0 & 105 & 1,5 \\
Itaim Bibi & 92.570 & 223 & 2,4 & 81 & 0,9 \\
Barra Funda & 14.383 & 28 & 1,9 & 8 & 0,6 \\
Brás & 29.165 & 170 & 5,8 & 130 & 4,5 \\
Pinheiros & 65.364 & 94 & 1,4 & 23 & 0,4 \\
Consolação & 57.365 & 47 & 0,8 & 7 & 0,1 \\
Moema & 83.368 & 69 & 0,8 & 18 & 0,2 \\
Santa Cecília & 83.717 & 122 & 1,5 & 76 & 0,9 \\
Jd. Paulista & 88.692 & 45 & 0,5 & 9 & 0,1 \\
Bela Vista & 69.460 & 60 & 0,9 & 44 & 0,6 \\
\hline
\end{tabular}


Tabela A.19. Fraudes na categoria industrial por unidade de negócio

\begin{tabular}{l|c|c}
\hline Unidade de negócio & $\begin{array}{c}\text { Quantidade de } \\
\text { fraudes }\end{array}$ & $\%$ \\
\hline Centro & 323 & $22 \%$ \\
Sul & 298 & $20 \%$ \\
Leste & 438 & $30 \%$ \\
Norte & 259 & $18 \%$ \\
Oeste & 158 & $11 \%$ \\
\hline Total & 1.476 & $100 \%$ \\
\hline
\end{tabular}

Tabela A.20. Atendimentos comerciais com maior número de fraudes industriais

\begin{tabular}{l|c|c}
\hline \multicolumn{1}{c|}{$\begin{array}{c}\text { Atendimento } \\
\text { Comercial }\end{array}$} & Quantidade de fraudes & $\%$ \\
\hline Sé & 103 & $7 \%$ \\
Penha & 94 & $6 \%$ \\
São Miguel & 90 & $6 \%$ \\
Santo Amaro & 90 & $6 \%$ \\
Mooca & 72 & $5 \%$ \\
Itaim Paulista & 52 & $4 \%$ \\
Santana & 51 & $3 \%$ \\
Campo Limpo & 43 & $3 \%$ \\
Demais Atendimentos & 881 & $44 \%$ \\
\hline
\end{tabular}

Tabela A.21. Registro de BO por município e distrito

\begin{tabular}{l|c|c}
\hline \multicolumn{1}{c|}{ Município / Distrito } & Quantidade BOs & $\%$ \\
\hline Osasco & 37 & $8,5 \%$ \\
Itaquaquecetuba & 32 & $7,4 \%$ \\
República & 19 & $4,3 \%$ \\
Pirituba & 18 & $4,1 \%$ \\
Barueri & 16 & $3,6 \%$ \\
Santana & 12 & $2,7 \%$ \\
Vila Maria & 11 & $2,5 \%$ \\
Casa Verde & 10 & $2,3 \%$ \\
Rio Pequeno & 10 & $2,3 \%$ \\
Taboão da Serra & 10 & $2,3 \%$ \\
Ipiranga & 9 & $2,0 \%$ \\
Santana de Parnaíba & 9 & $2,0 \%$ \\
& & "continua" \\
& & "continuação"
\end{tabular}




\begin{tabular}{|c|c|c|}
\hline Município / Distrito & Quantidade BOs & $\%$ \\
\hline Vila Guilherme & 9 & $2,0 \%$ \\
\hline Barra Funda & 8 & $1,8 \%$ \\
\hline Brás & 8 & $1,8 \%$ \\
\hline Vila Nova Cachoeirinha & 8 & $1,8 \%$ \\
\hline Butantã & 7 & $1,6 \%$ \\
\hline Carapicuíba & 7 & $1,6 \%$ \\
\hline Freguesia do Ó & 7 & $1,6 \%$ \\
\hline São Domingos & 7 & $1,6 \%$ \\
\hline Tucuruvi & 7 & $1,6 \%$ \\
\hline Brasilândia & 6 & $1,4 \%$ \\
\hline Liberdade & 6 & $1,4 \%$ \\
\hline Sé & 6 & $1,4 \%$ \\
\hline Itaim Paulista & 5 & $1,1 \%$ \\
\hline Jaçanã & 5 & $1,1 \%$ \\
\hline Jaguaré & 5 & $1,1 \%$ \\
\hline Perdizes & 5 & $1,1 \%$ \\
\hline Vila Mariana & 5 & $1,1 \%$ \\
\hline Pinheiros & 5 & $1,1 \%$ \\
\hline Vila Medeiros & 5 & $1,1 \%$ \\
\hline Cajamar & 4 & $0,9 \%$ \\
\hline Cidade Ademar & 4 & $0,9 \%$ \\
\hline Cidade Dutra & 4 & $0,9 \%$ \\
\hline Itaquera & 4 & $0,9 \%$ \\
\hline Mandaqui & 4 & $0,9 \%$ \\
\hline Morumbi & 4 & $0,9 \%$ \\
\hline Perus & 4 & $0,9 \%$ \\
\hline Santo Amaro & 4 & $0,9 \%$ \\
\hline São Miguel Paulista & 4 & $0,9 \%$ \\
\hline São Bernardo do Campo & 4 & $0,9 \%$ \\
\hline Suzano & 4 & $0,9 \%$ \\
\hline Água Rasa & 3 & $0,7 \%$ \\
\hline Americanópolis & 3 & $0,7 \%$ \\
\hline Bela Vista & 3 & $0,7 \%$ \\
\hline Belém & 3 & $0,7 \%$ \\
\hline Cangaíba & 3 & $0,7 \%$ \\
\hline Cotia & 3 & $0,7 \%$ \\
\hline Itaim Bibi & 3 & $0,7 \%$ \\
\hline Jandira & 3 & $0,7 \%$ \\
\hline Jaraguá & 3 & $0,7 \%$ \\
\hline Lapa & 3 & $0,7 \%$ \\
\hline
\end{tabular}


"continuação"

\begin{tabular}{|c|c|c|}
\hline Município / Distrito & Quantidade BOs & $\%$ \\
\hline Mairiporã & 3 & $0,7 \%$ \\
\hline Socorro & 3 & $0,7 \%$ \\
\hline Vila Matilde & 3 & $0,7 \%$ \\
\hline Campo Limpo & 2 & $0,5 \%$ \\
\hline Ferraz de Vasconcelos & 2 & $0,5 \%$ \\
\hline Itapevi & 2 & $0,5 \%$ \\
\hline Parelheiros & 2 & $0,5 \%$ \\
\hline Raposo Tavares & 2 & $0,5 \%$ \\
\hline São Matheus & 2 & $0,5 \%$ \\
\hline Sapopemba & 2 & $0,5 \%$ \\
\hline Saúde & 2 & $0,5 \%$ \\
\hline Vila Jacuí & 2 & $0,5 \%$ \\
\hline Vila Sônia & 2 & $0,5 \%$ \\
\hline Artur Alvim & 1 & $0,2 \%$ \\
\hline Arujá & 1 & $0,2 \%$ \\
\hline Bom Retiro & 1 & $0,2 \%$ \\
\hline Bragança Paulista & 1 & $0,2 \%$ \\
\hline Campo Belo & 1 & $0,2 \%$ \\
\hline Campo Grande & 1 & $0,2 \%$ \\
\hline Carrão & 1 & $0,2 \%$ \\
\hline Cidade Líder & 1 & $0,2 \%$ \\
\hline Consolação & 1 & $0,2 \%$ \\
\hline Ermelino Matarazzo & 1 & $0,2 \%$ \\
\hline Franco da Rocha & 1 & $0,2 \%$ \\
\hline Itapecerica da Serra & 1 & $0,2 \%$ \\
\hline Jaguará & 1 & $0,2 \%$ \\
\hline Jardim Ângela & 1 & $0,2 \%$ \\
\hline Limão & 1 & $0,2 \%$ \\
\hline Mooca & 1 & $0,2 \%$ \\
\hline Penha & 1 & $0,2 \%$ \\
\hline Tatuapé & 1 & $0,2 \%$ \\
\hline Vila Andrade & 1 & $0,2 \%$ \\
\hline Vila Curuçá & 1 & $0,2 \%$ \\
\hline Fila Formosa & 1 & $0,2 \%$ \\
\hline Vila Leopoldina & 1 & $0,2 \%$ \\
\hline Vila Prudente & 1 & $0,2 \%$ \\
\hline Total & 440 & $100 \%$ \\
\hline
\end{tabular}


Tabela A.22. Registro de B.O. por unidade de negócio

\begin{tabular}{l|c|c}
\hline Unidade de Negócio & Quantidade de BOs & $\%$ \\
\hline Norte & 128 & $29,1 \%$ \\
Oeste & 118 & $26,8 \%$ \\
Centro & 99 & $22,5 \%$ \\
Leste & 63 & $14,3 \%$ \\
Sul & 32 & $7,3 \%$ \\
\hline Total & 440 & $100,00 \%$ \\
\hline
\end{tabular}

Tabela A.23. Registro de B. O. por categoria de uso

\begin{tabular}{c|c|r}
\hline Categoria de Uso & $\begin{array}{c}\text { Comercial/ } \\
\text { Industrial }\end{array}$ & \multicolumn{2}{|c}{$\%$} \\
\hline Comercial/Industrial & 373 & $85 \%$ \\
Residencial/Mista & 67 & $15 \%$ \\
\hline TOTAL & 440 & $100,00 \%$ \\
\hline
\end{tabular}

Tabela A. 24. Média de fraudes por mês por Unidade de Negócio e categoria de uso

\begin{tabular}{c|c|c|c|c|c|c|c|c|c|c}
\hline Fraudes & \multicolumn{9}{c}{ Unidade de Negócio } \\
\hline & \multicolumn{2}{|c|}{ Centro } & \multicolumn{2}{c}{ Norte } & \multicolumn{2}{c}{ Sul } & \multicolumn{2}{c}{ Leste } & \multicolumn{2}{c}{ Oeste } \\
\cline { 2 - 12 } & Resid. & Com.+Ind. & Resid. & Com.+Ind. & Resid. & Com.+Ind.. & Resid. & Com.+Ind. & Resid. & Com.+Ind. \\
\hline Mês & 97,9 & 38,3 & 406 & 27,4 & 207,3 & 35,4 & 404,7 & 32,9 & 212,3 & 19,4 \\
\hline
\end{tabular}

Tabela A. 25. Média de fraudes por mês por categoria de uso, município exceto São Paulo e distrito de SP

\begin{tabular}{|c|c|c|c|c|c|c|c|c|}
\hline Fraudes & \multicolumn{4}{|c|}{ Categoria de uso } & \multicolumn{2}{|c|}{$\begin{array}{c}\text { Município exceto São } \\
\text { Paulo }\end{array}$} & \multicolumn{2}{|c|}{ Distrito de São Paulo } \\
\hline & Residencial & Comercial & Industrial & Mista & Residencial & Comercial & Residencial & Comercial \\
\hline Mês & 1279,3 & 134,4 & 18,9 & 47,8 & 11,5 & 0,8 & 8,9 & 1,1 \\
\hline
\end{tabular}


Gráfico A.1. Taxa de fraudes por distrito pela proporção de habitantes em vulnerabilidade baixíssima

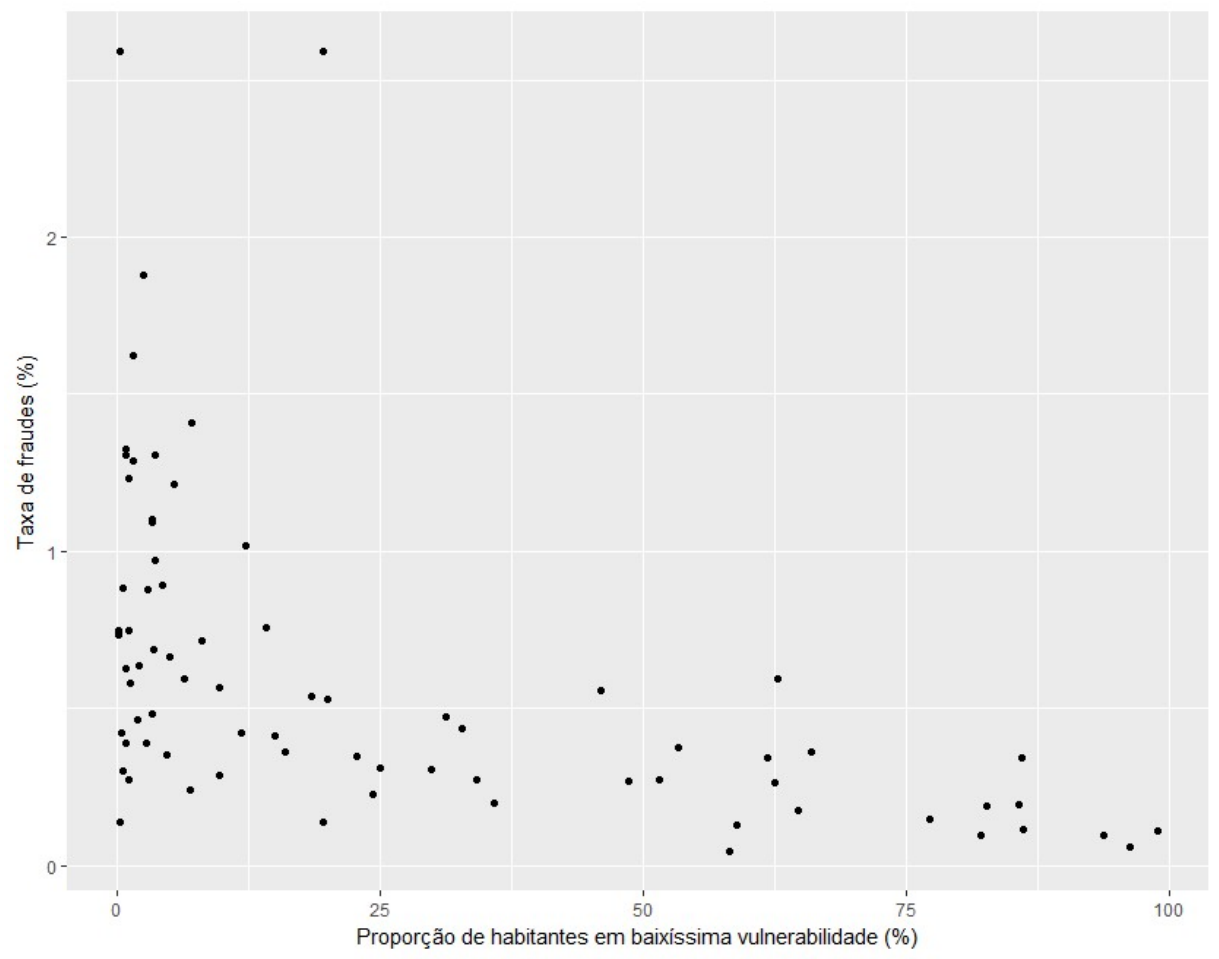

Gráfico A.2. Taxa de fraudes por distrito pela proporção de habitantes em vulnerabilidade muito baixa

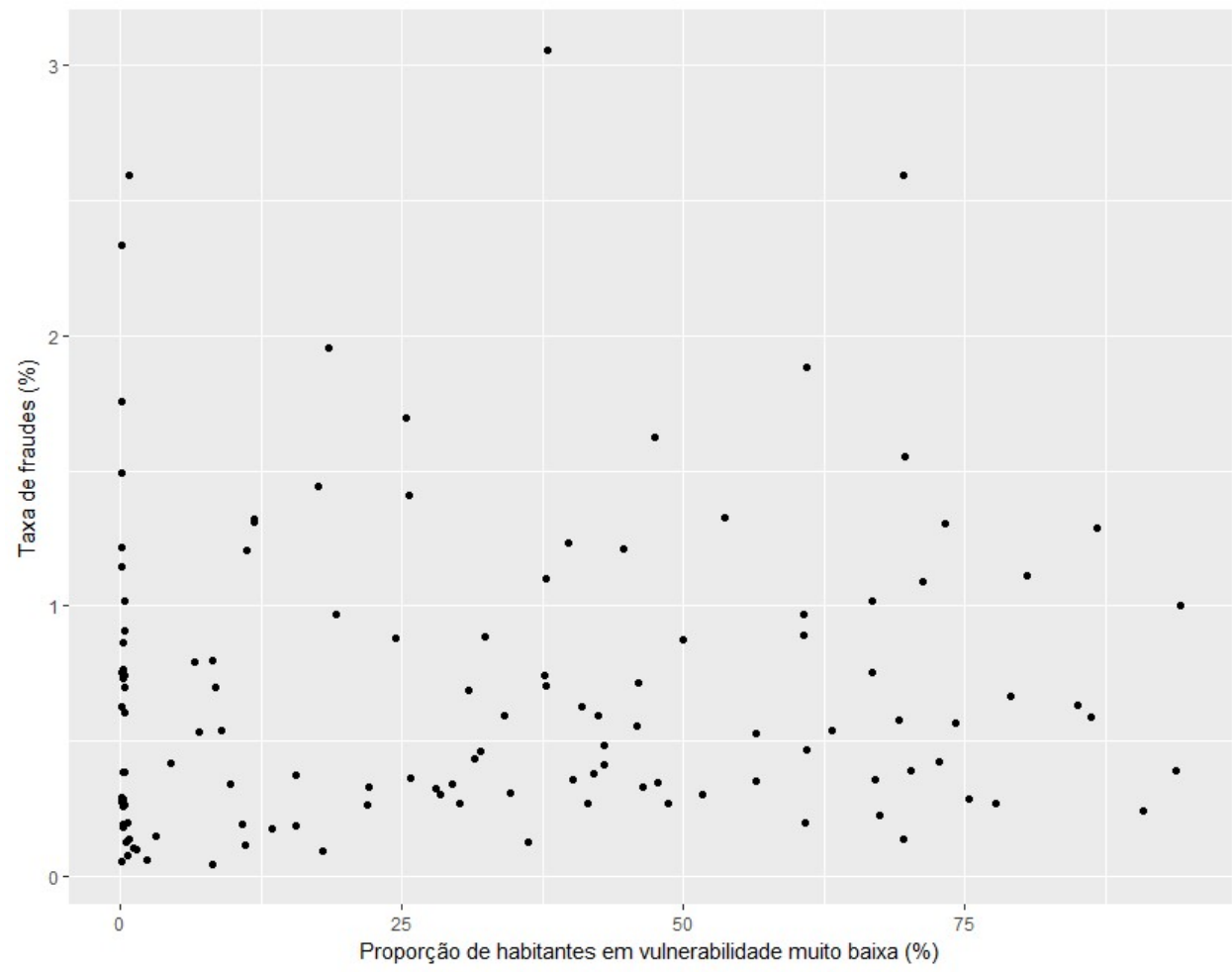


Gráfico A.3. Gráfico A.3. Taxa de fraudes por distrito pela proporção de habitantes em vulnerabilidade baixa

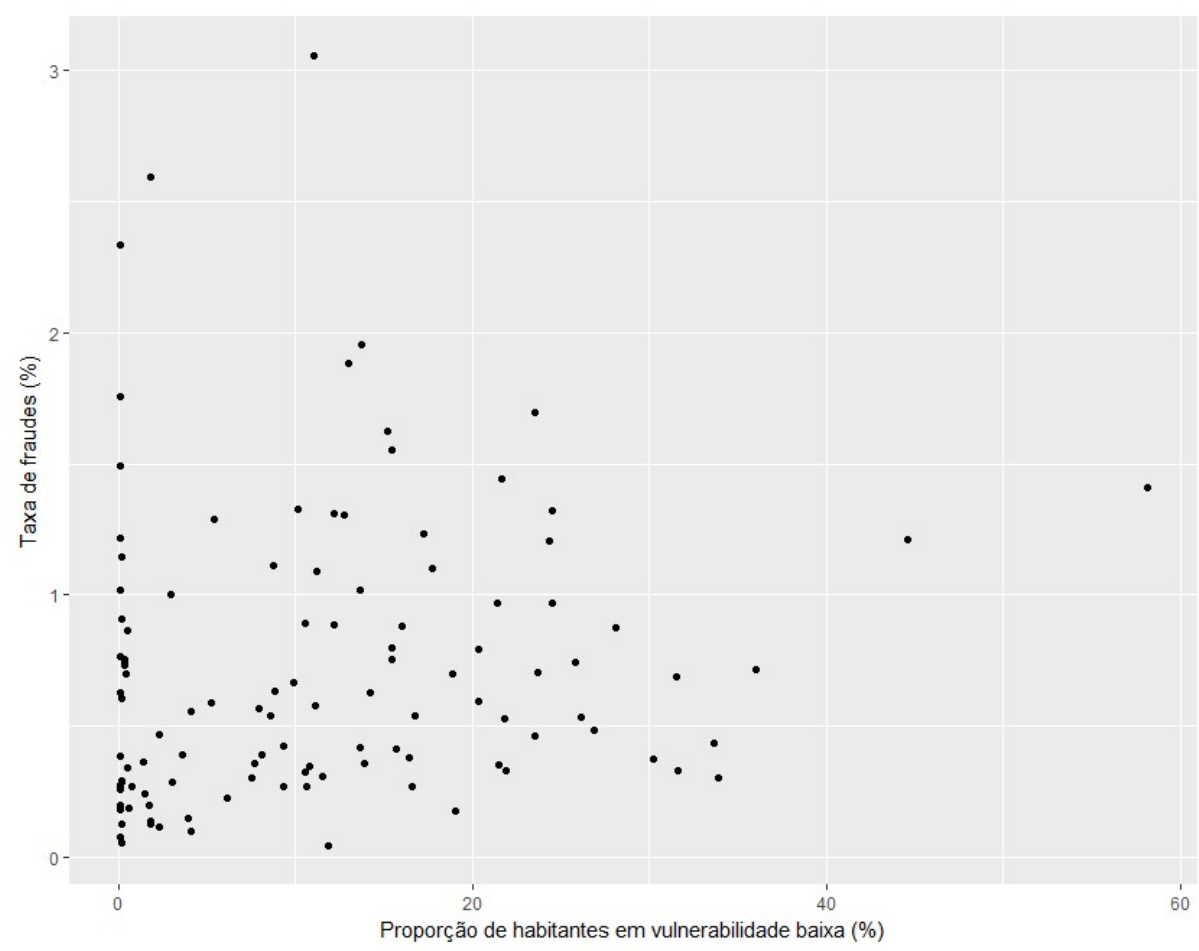

Gráfico A.4. Taxa de fraudes por distrito pela proporção de habitantes em vulnerabilidade média

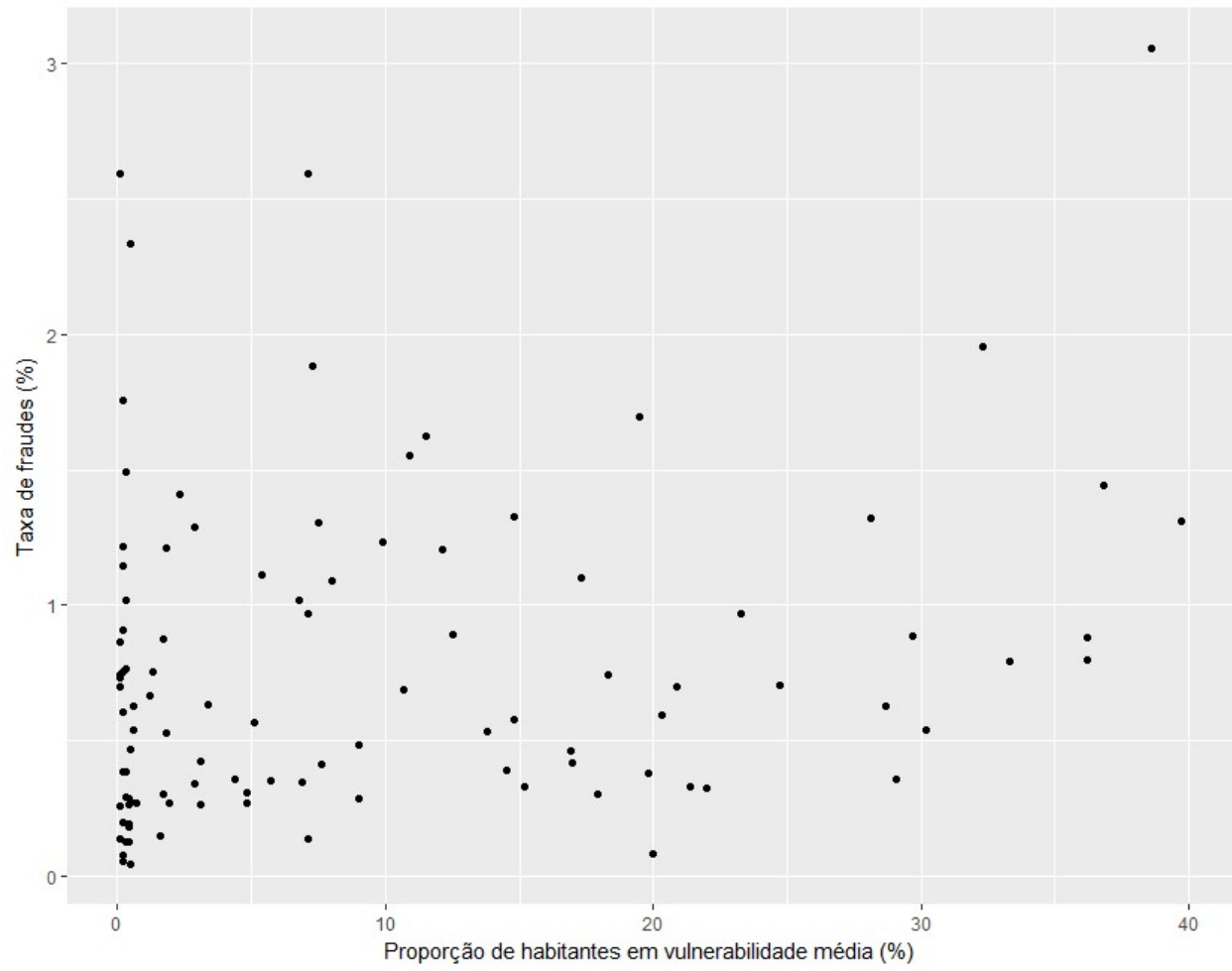


Gráfico A.5. Taxa de fraudes por distrito pela proporção de habitantes em vulnerabilidade alta (urbana)

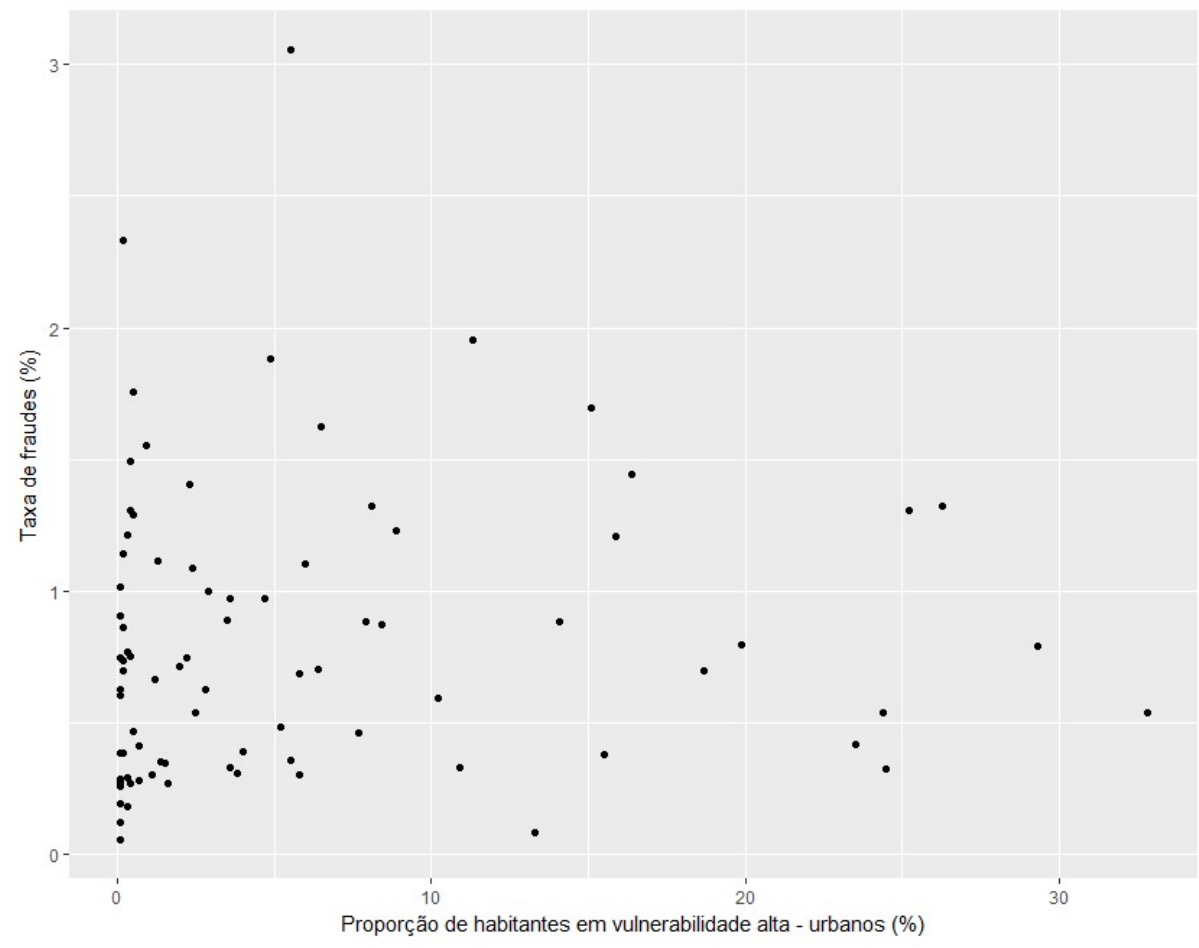

Gráfico A.6. Taxa de fraudes por distrito pela proporção de habitantes em vulnerabilidade muito alta (aglomerados urbanos)

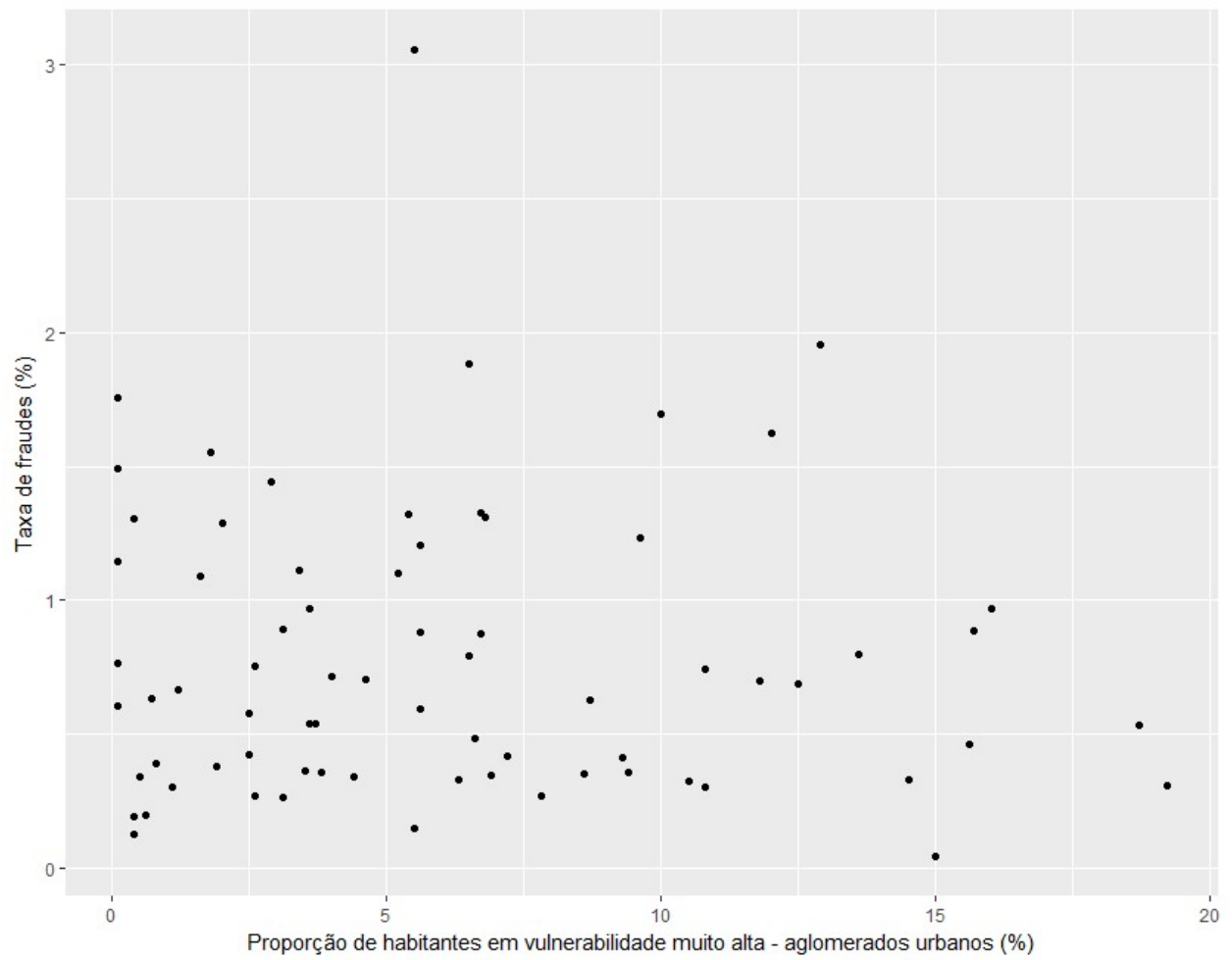


Gráfico A.7. Taxa de fraudes por distrito pela proporção de habitantes em vulnerabilidade alta (rural)

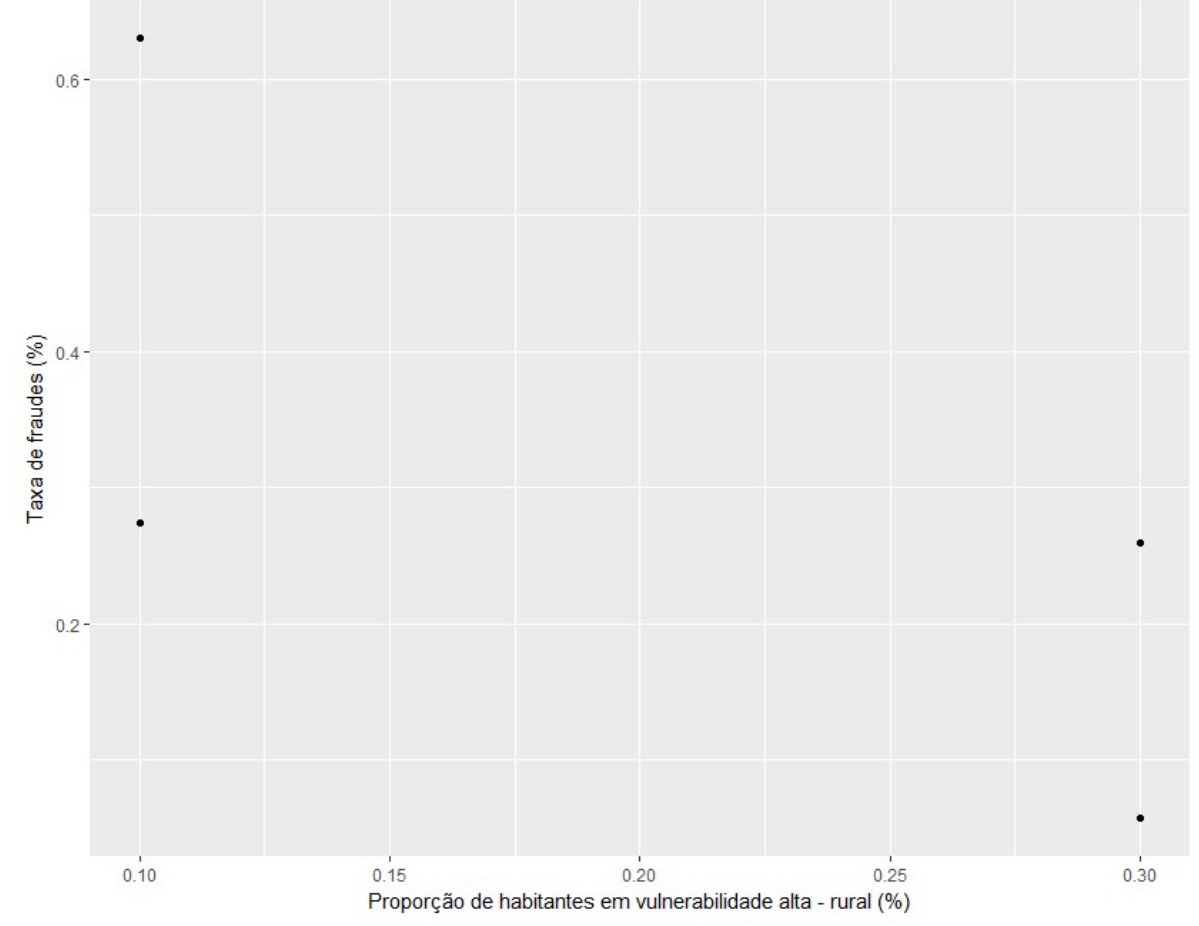




\section{APÊNDICE B}

Mapa B1. Mapa de calor em quartis da população por município

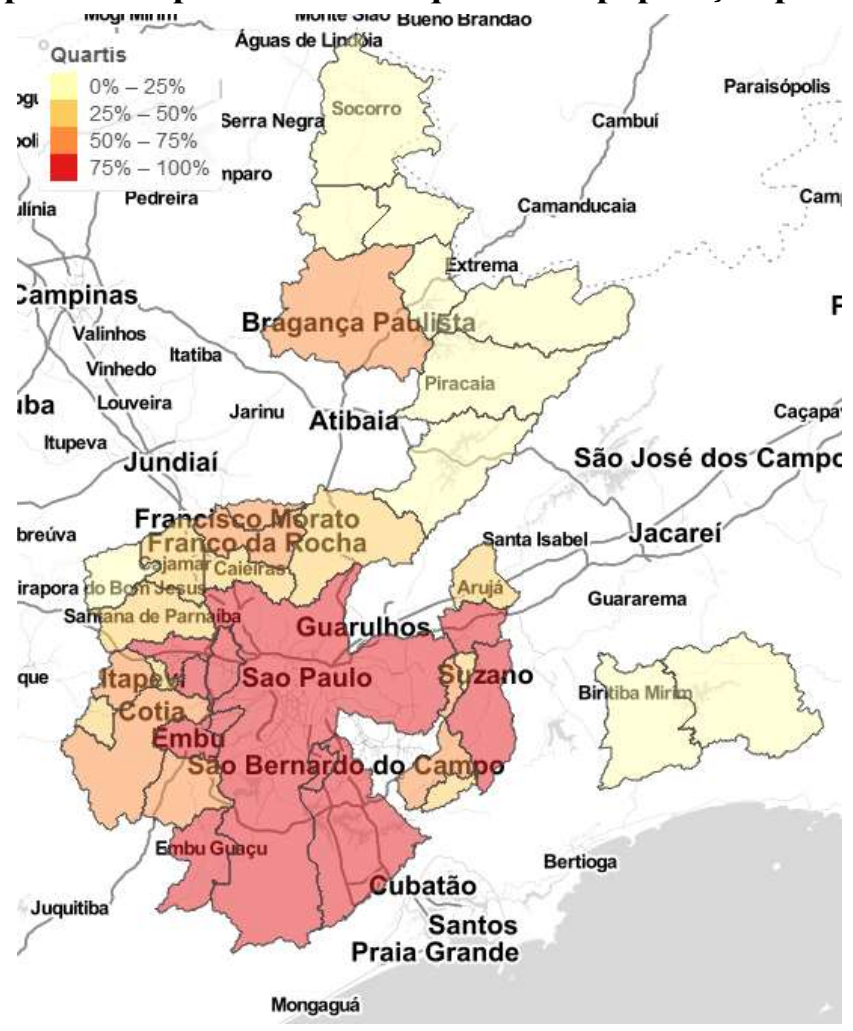

Mapa B2. Mapa de calor em quartis do número de fraudes por município

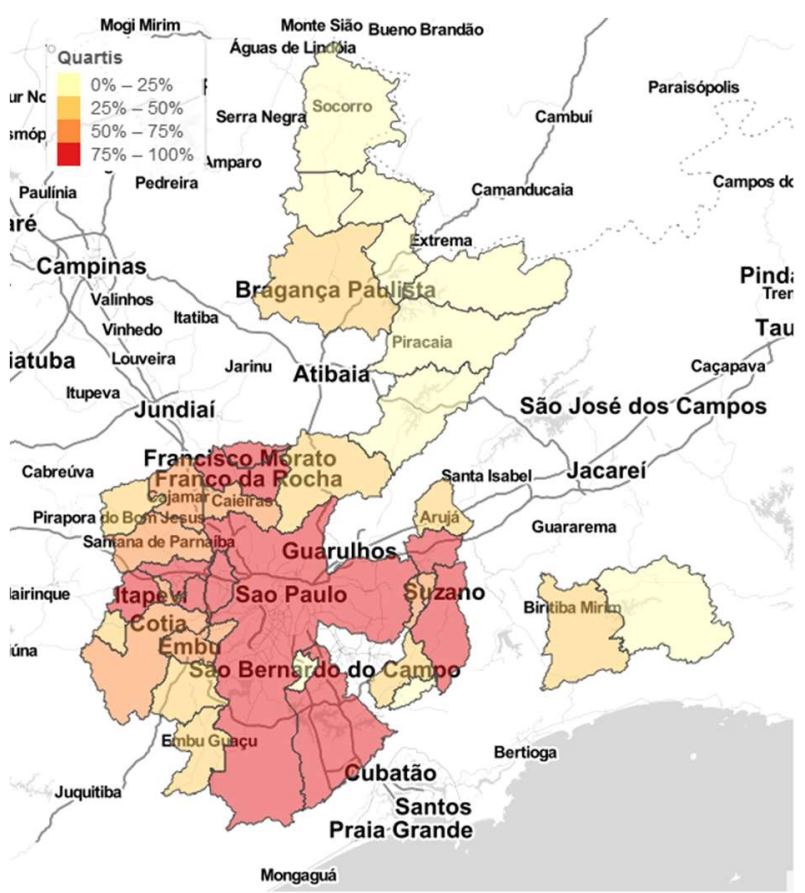


Mapa B3. Mapa de calor em quartis do número de fraudes residenciais por mil habitantes no nível de município

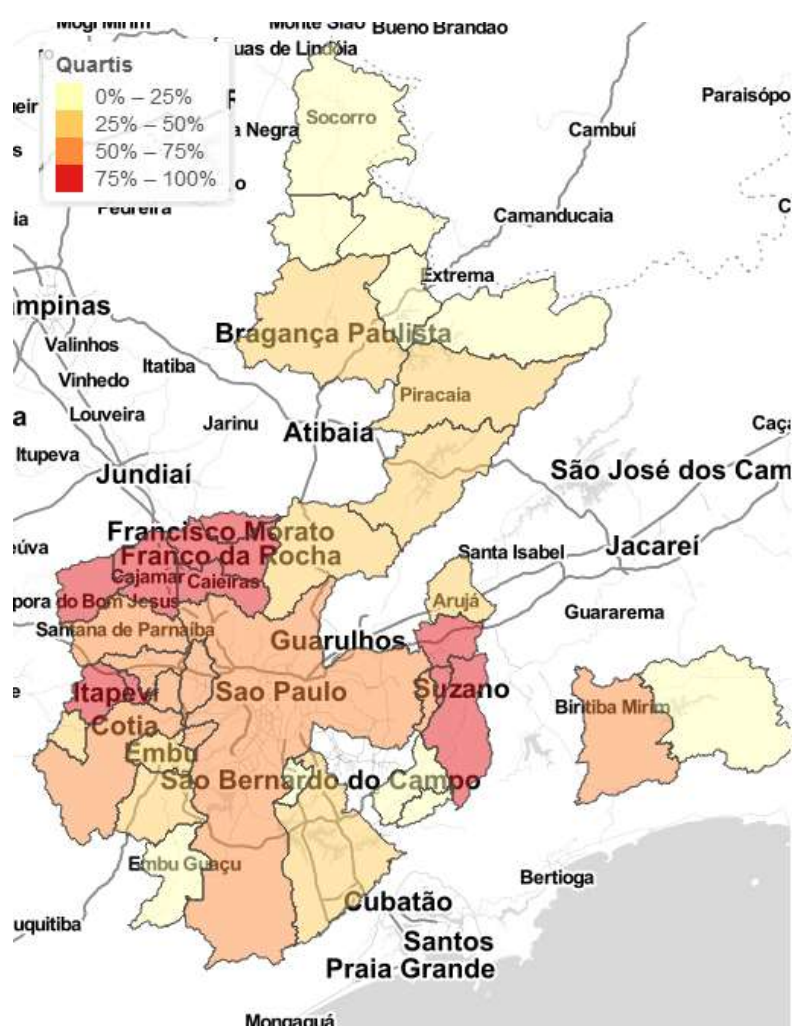

Mapa B4. Fraudes em Francisco Morato e Franco da Rocha no detalhe

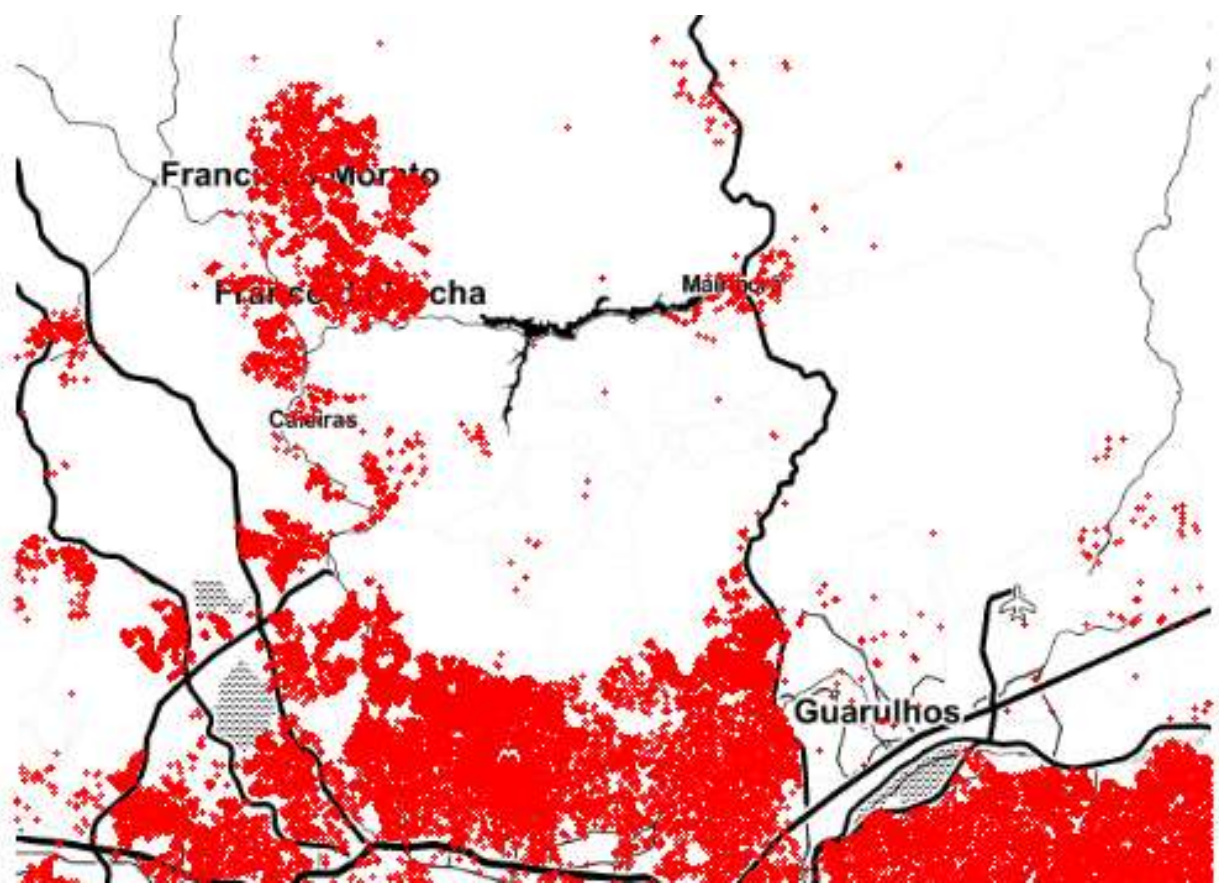


Mapa B5. Fraudes no município de São Paulo no detalhe

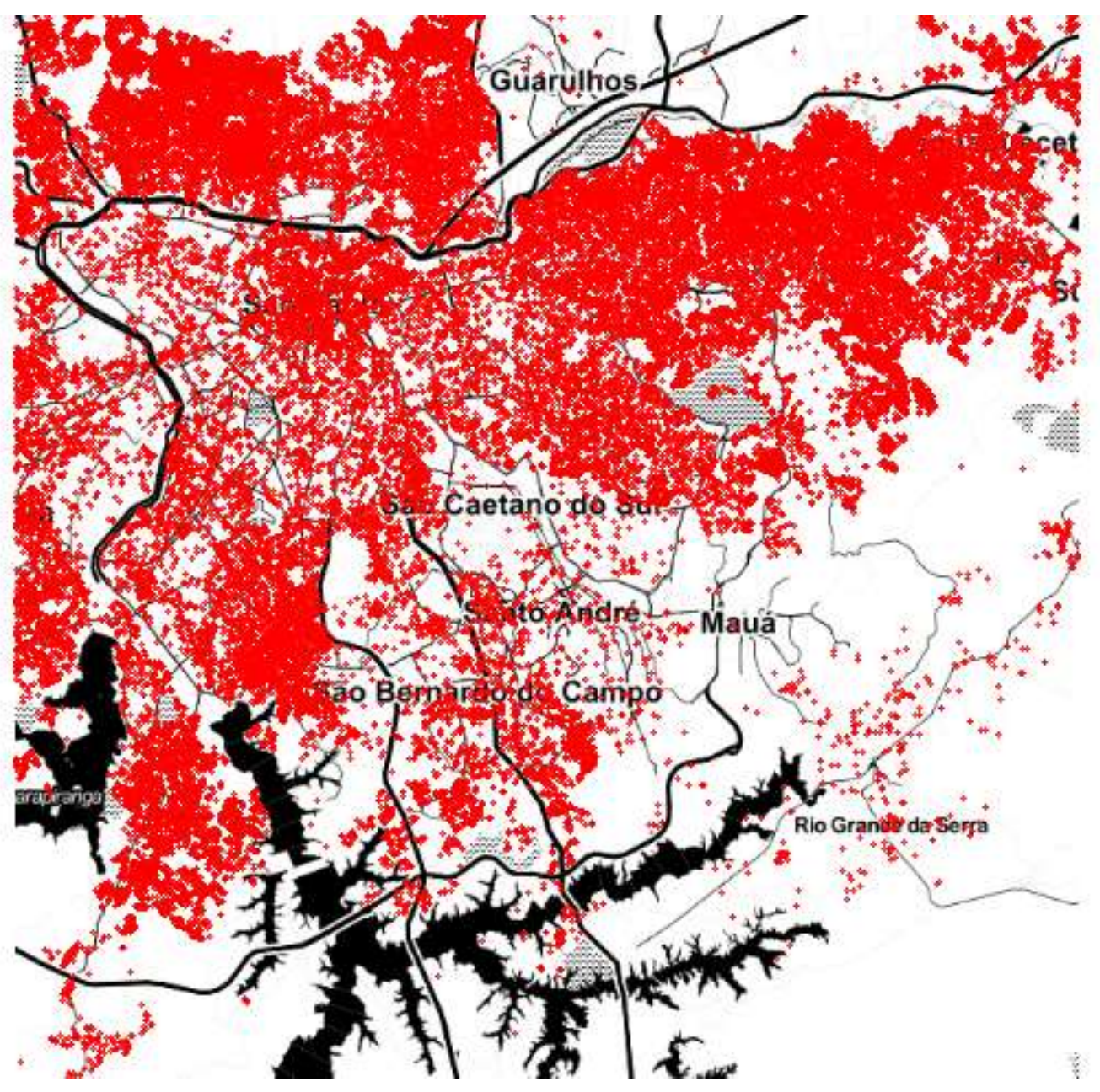


Mapa B.6 Mapa de calor em quartis da população por distrito

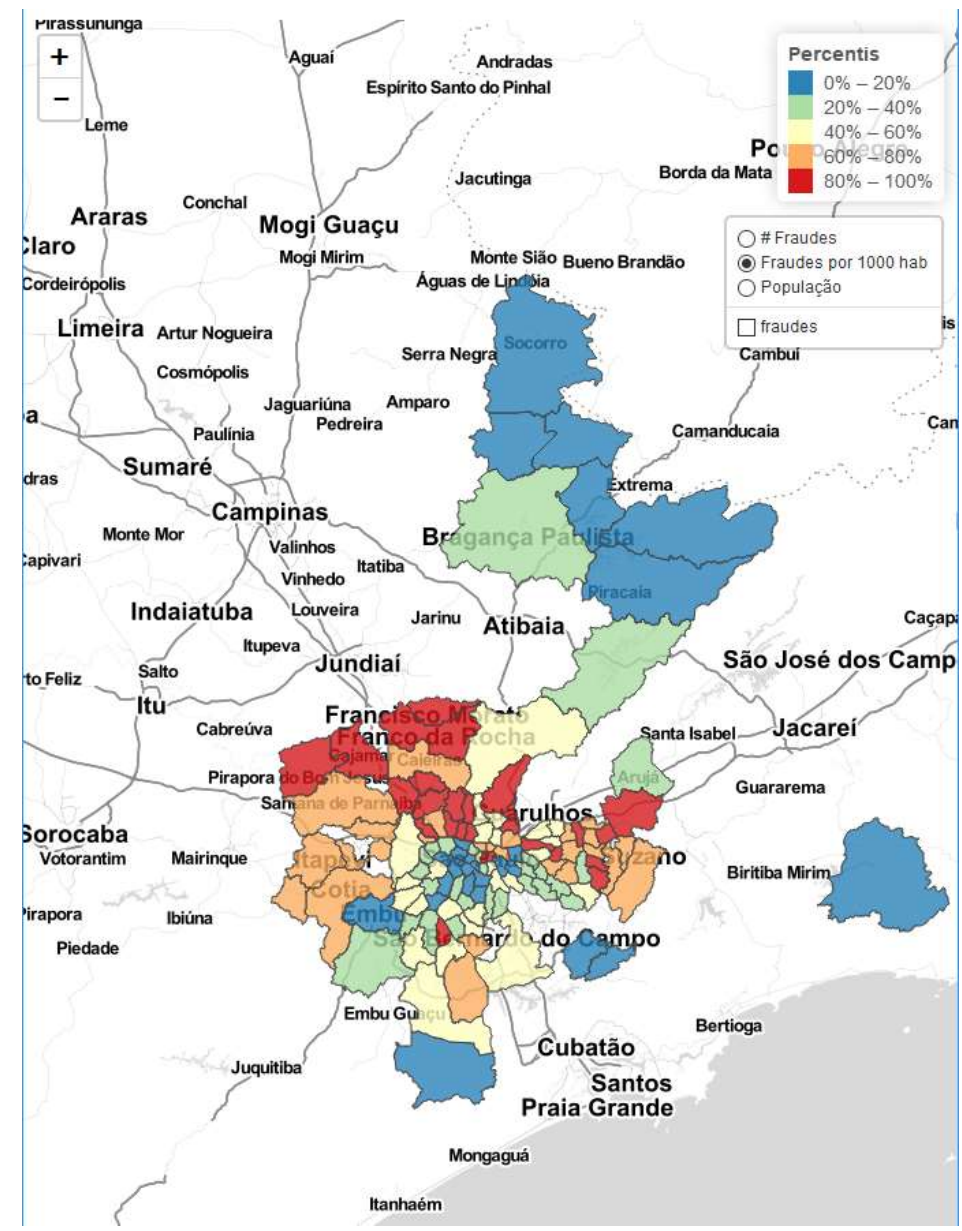


Mapa B.7 Mapa de calor em quartis do número de fraudes por distrito

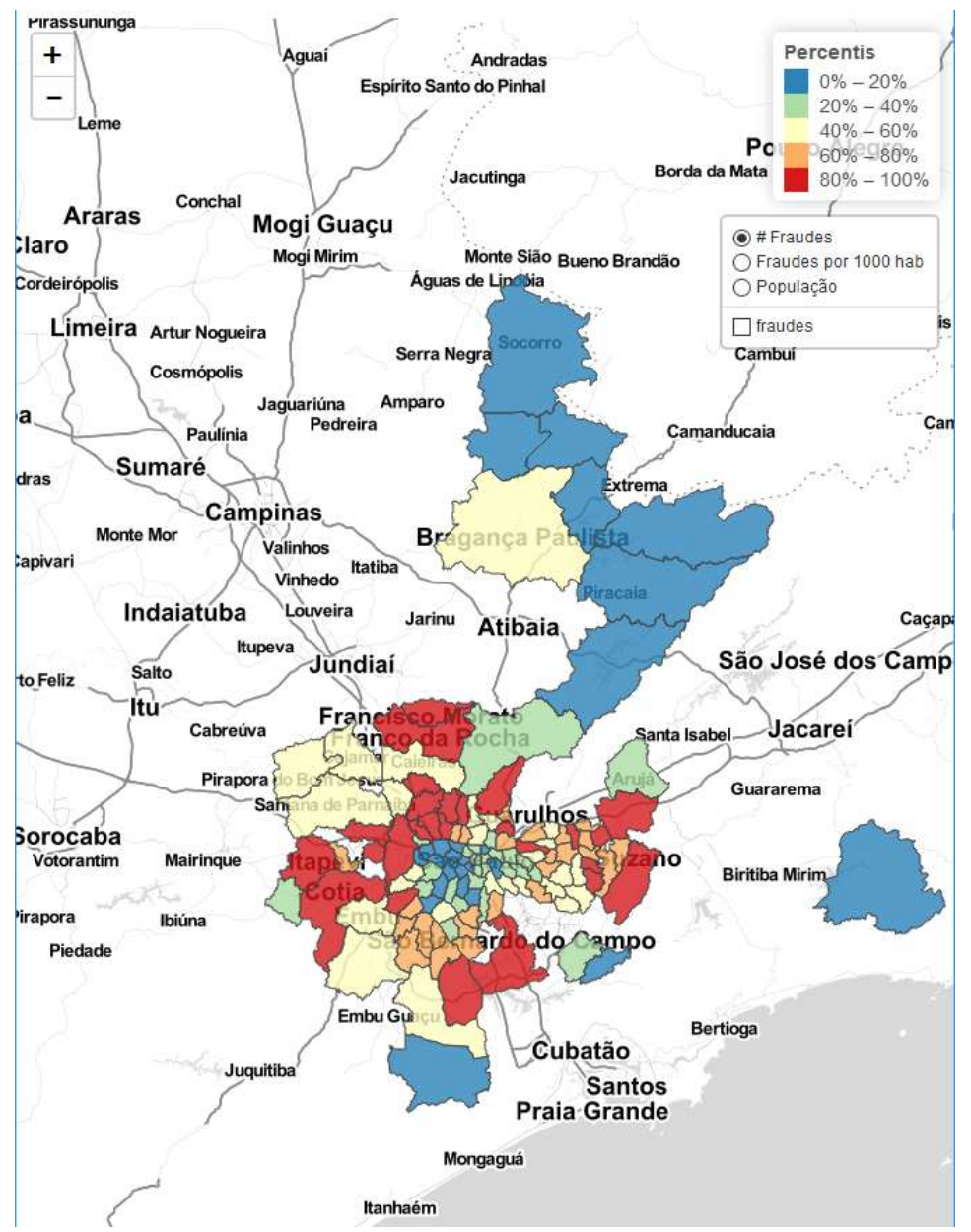


Mapa B.8 Mapa de calor em quartis do número de fraudes por mil habitantes no nível distrital

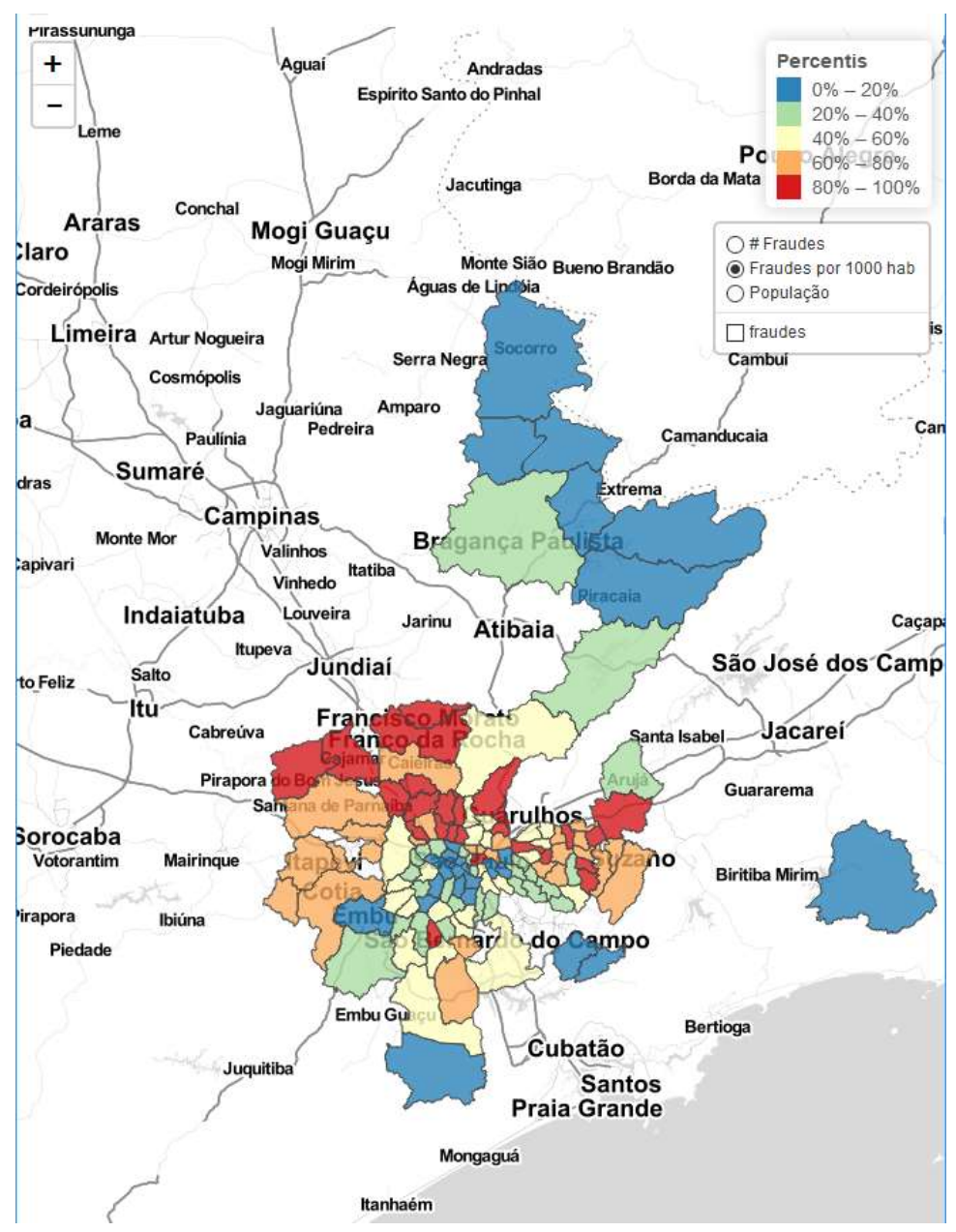


APÊNDICE C

Gráfico C.1. Fraudes por mês

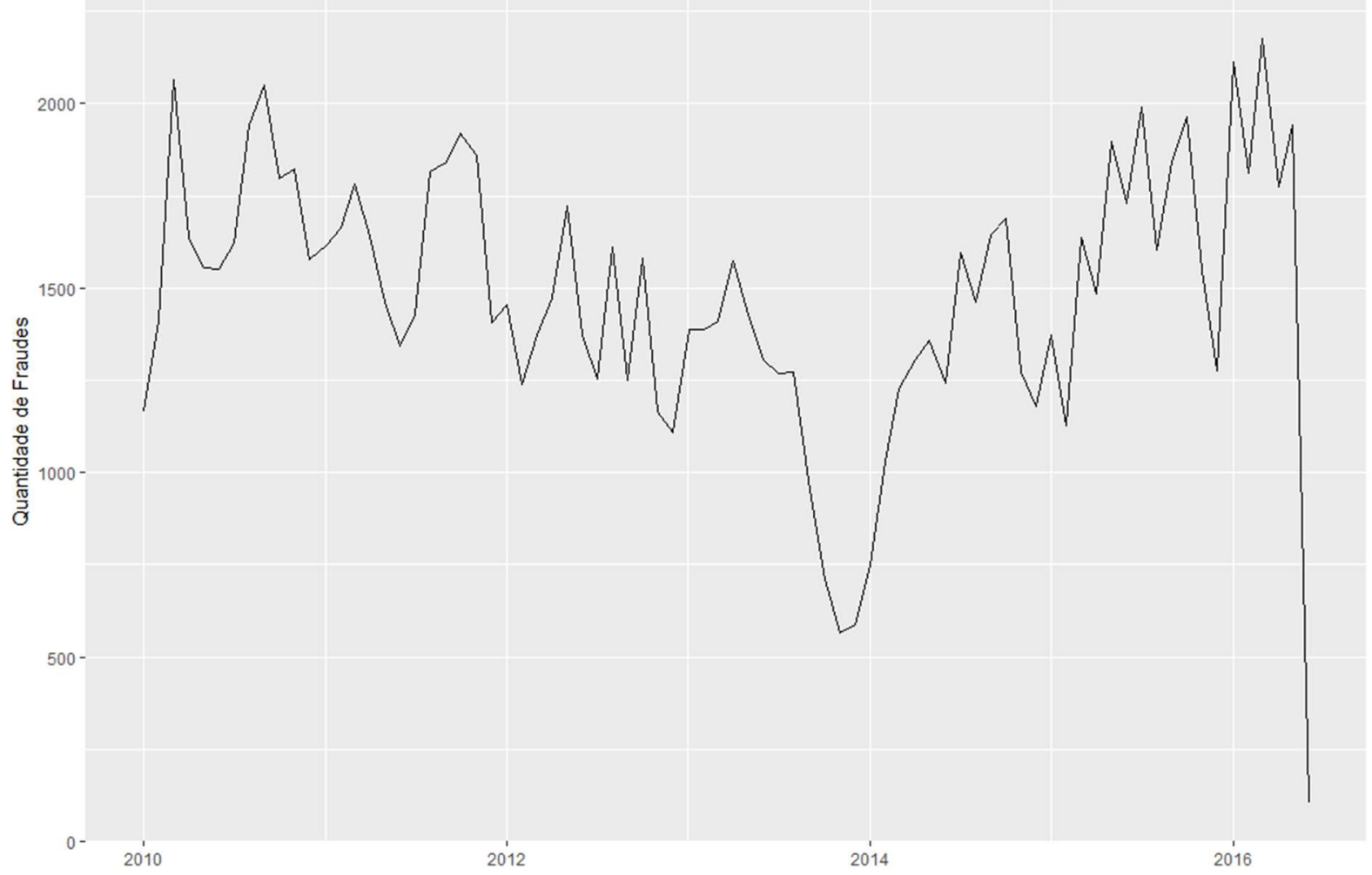

Gráfico C.2. Fraudes e vistorias por mês

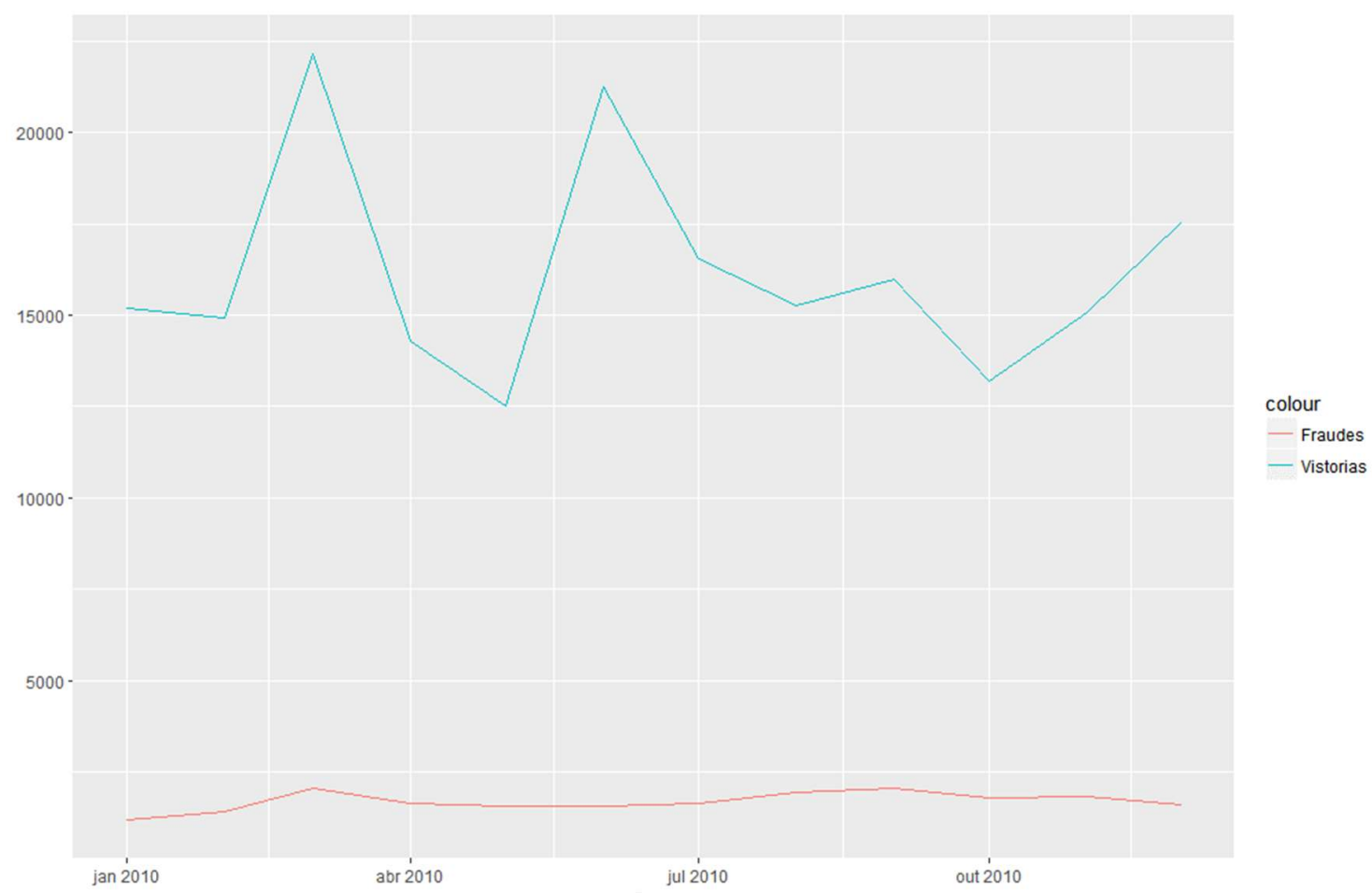


Gráfico C.3. Fraudes por unidades de negócio

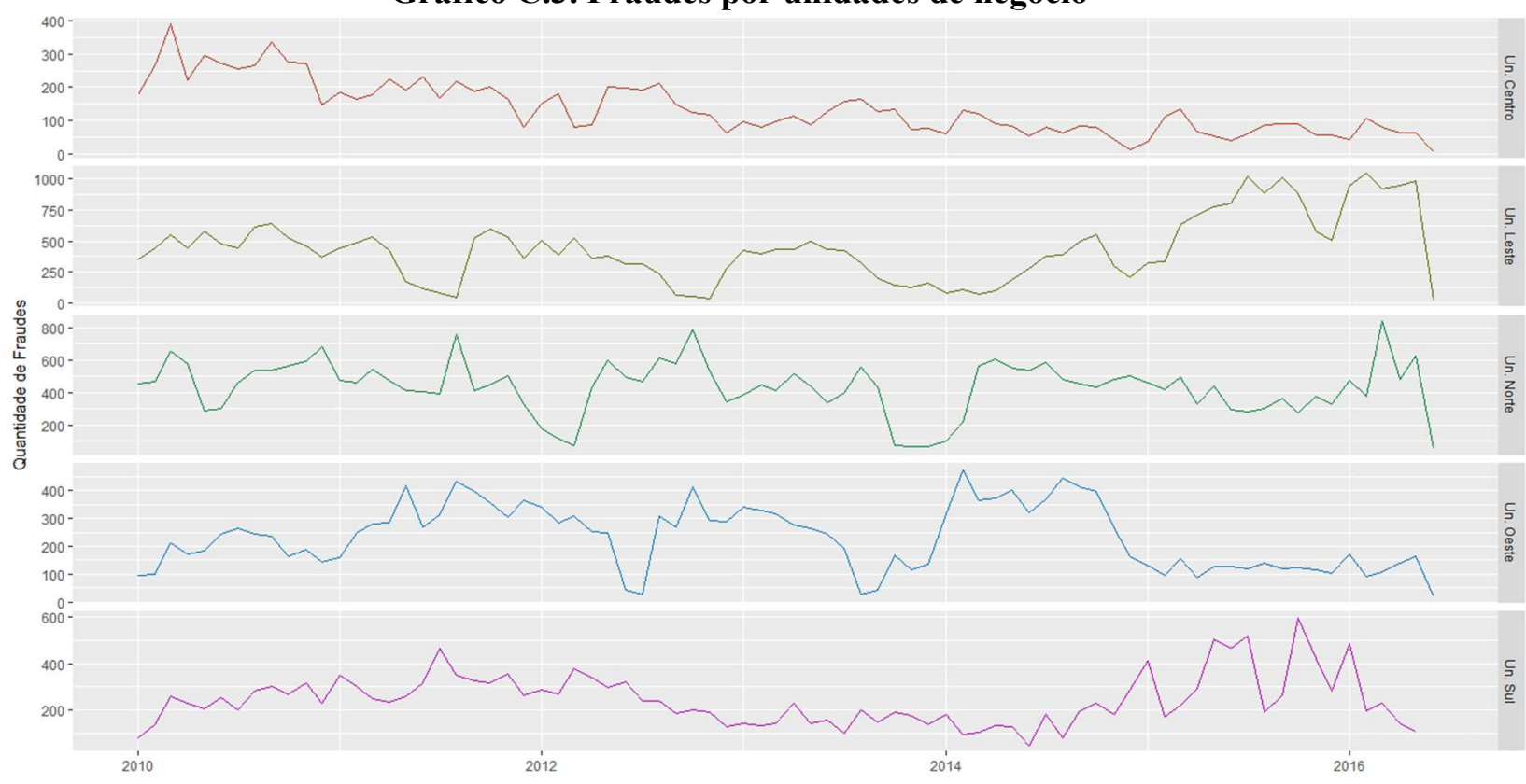

Gráfico C.4. Fraudes por unidades de negócio por mês - categoria residencial

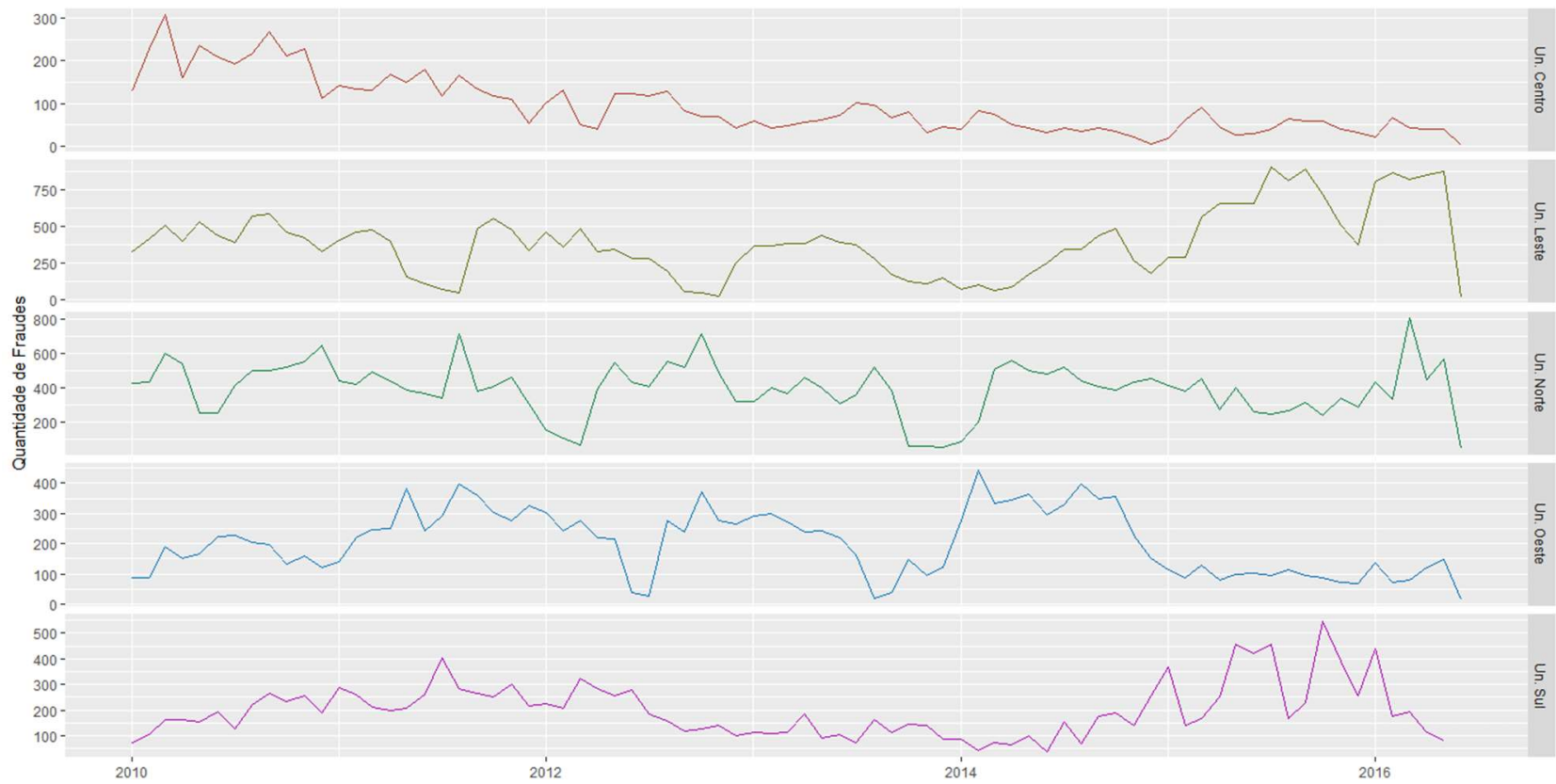


Gráfico C.5. Fraudes por Unidade de negócio por mês - categoria comercial

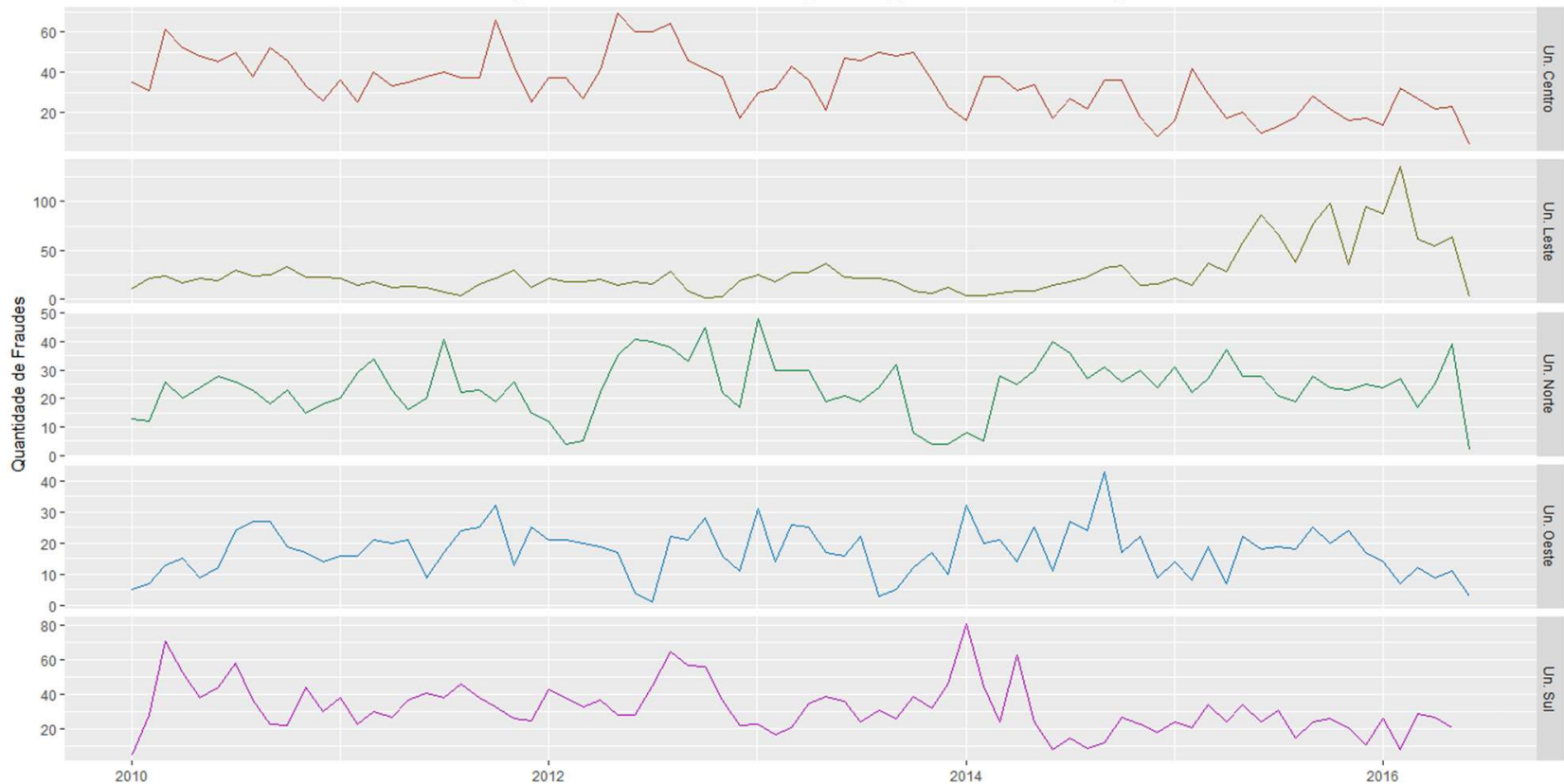

Gráfico C.6. Fraudes por categoria de uso por mês

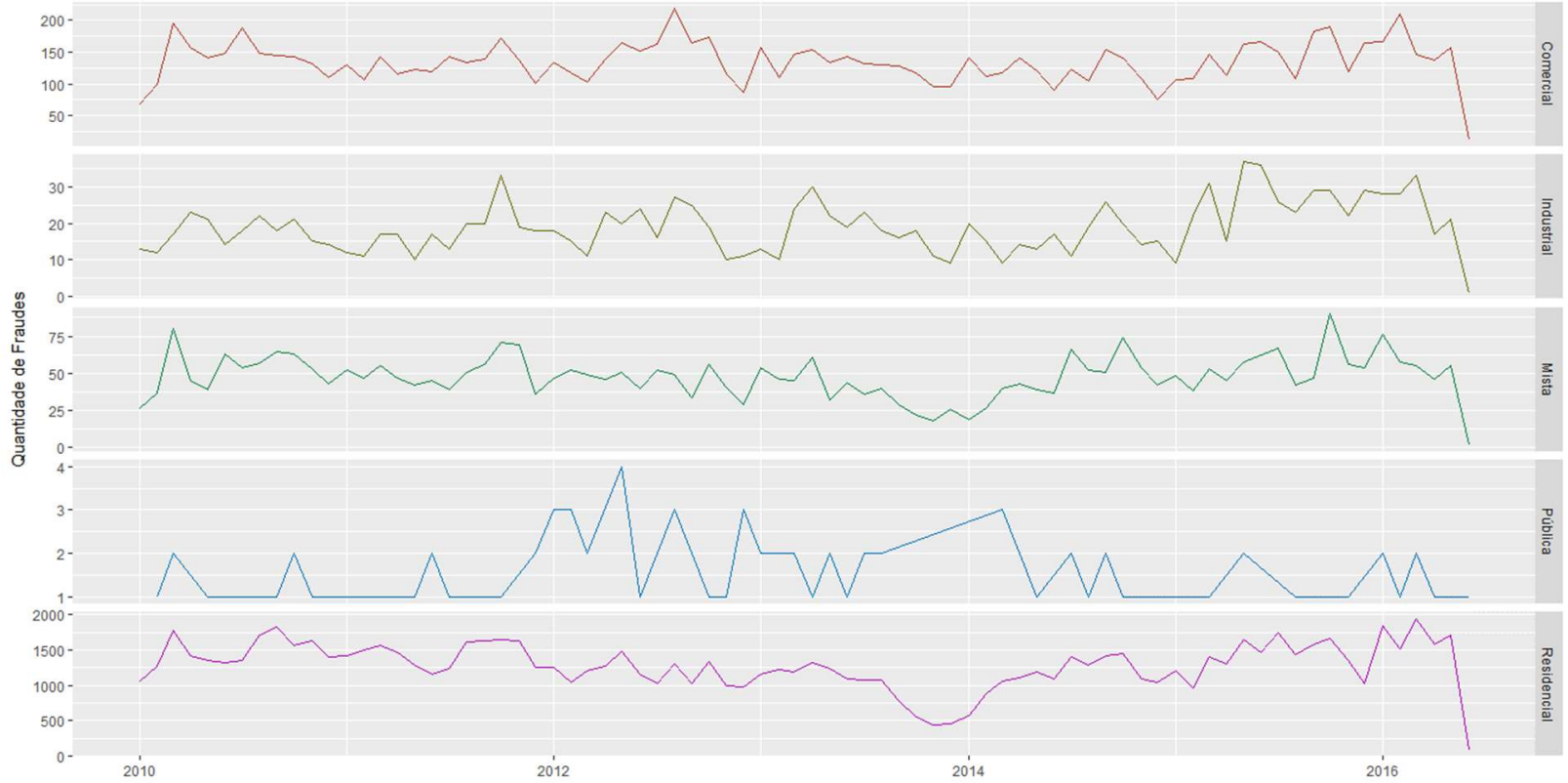


Gráfico C.7. Fraudes segundo o tipo de ligação

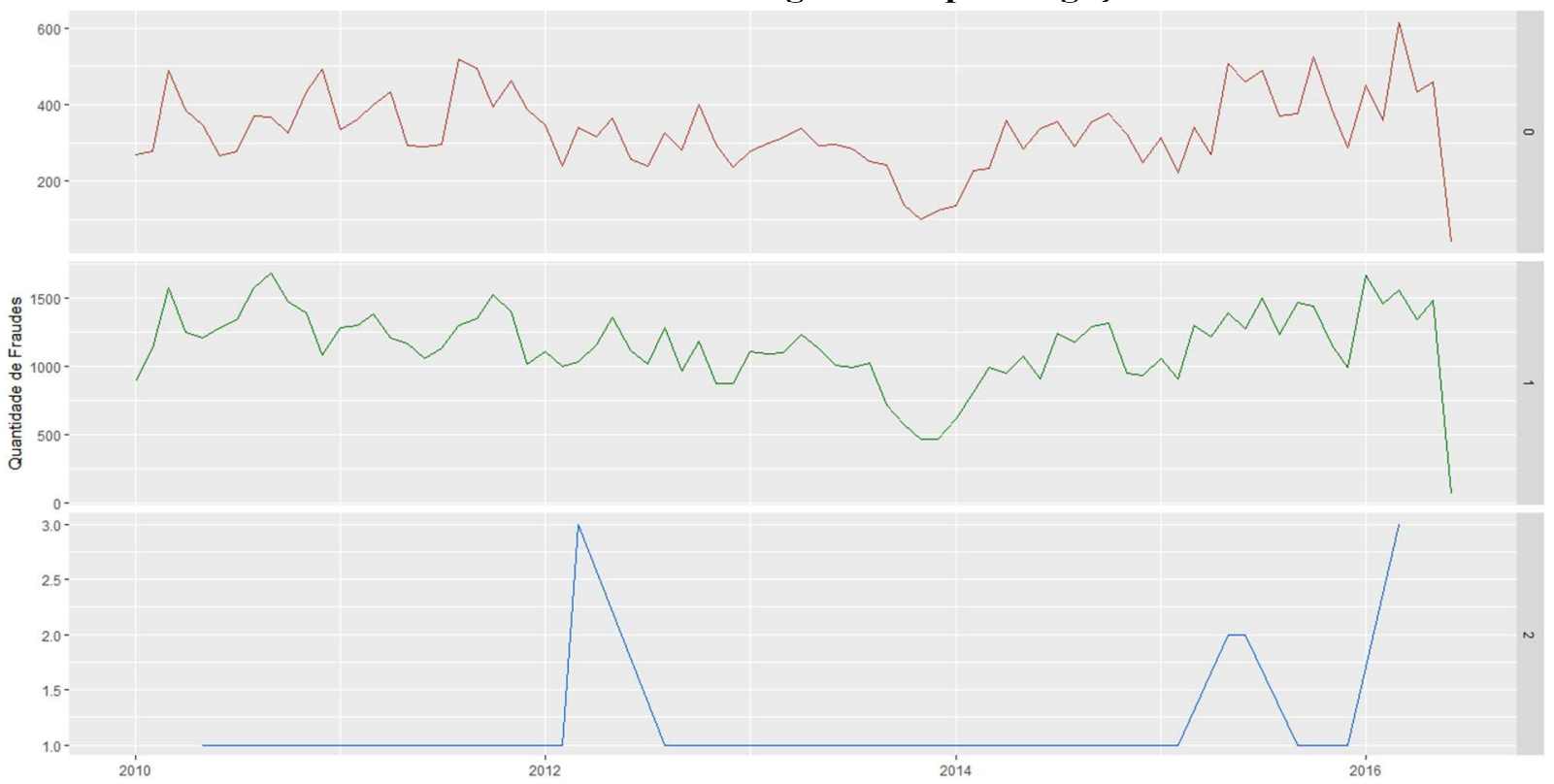

Gráfico C.8. Fraudes por faixas de economias

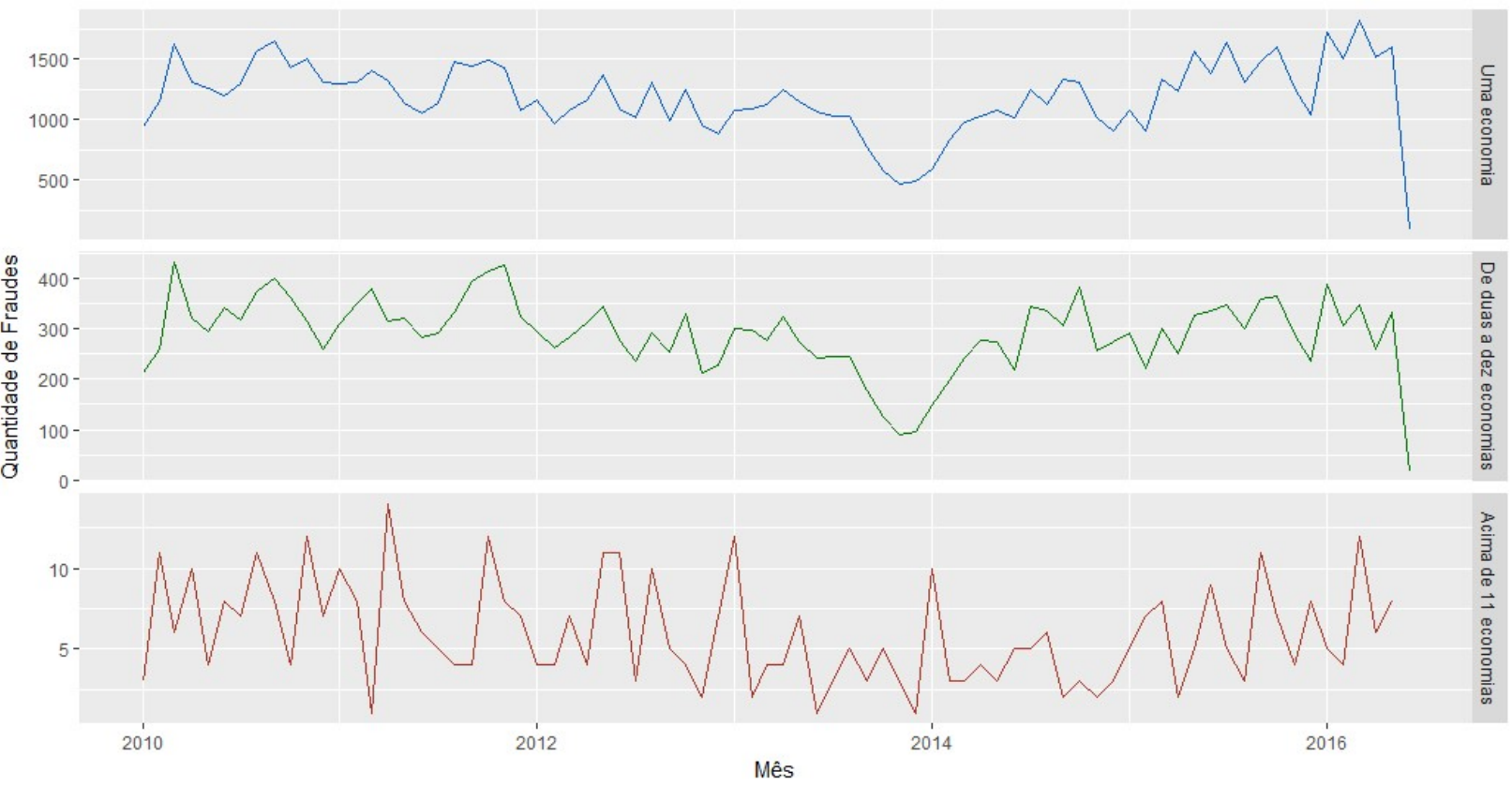


Gráfico C.9. Fraudes por faixa de consumo médio

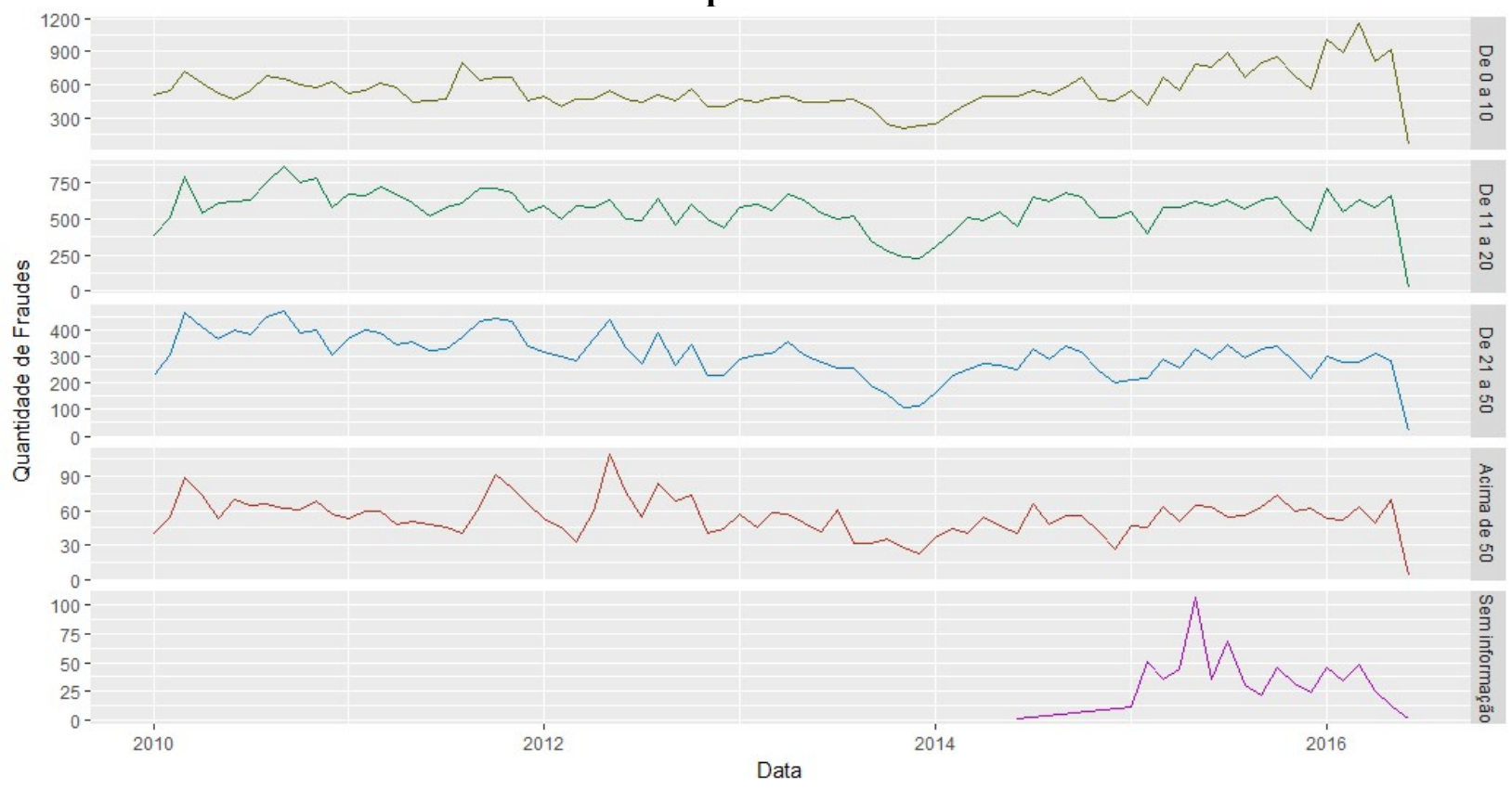

